\title{
Change of Selectivity in C-H Functionalization Promoted by Nonheme Iron(IV)-oxo Complexes by Effect of N-hydroxyphthalimide HAT Mediator
}

Marika Di Berto Mancini, ${ }^{a}$ Andrea Del Gelsomino, ${ }^{a}$ Stefano Di Stefano, ${ }^{a}$ Federico Frateloreto, ${ }^{a}$ Andrea Lapi, ${ }^{a}$ Osvaldo Lanzalunga, ${ }^{a, b}{ }^{*}$ Giorgio Olivo, ${ }^{a}$ and Stefano Sajeva ${ }^{a}$

\footnotetext{
${ }^{a}$ Dipartimento di Chimica and Istituto CNR per i Sistemi Biologici (ISB-CNR), Sezione Meccanismi di Reazione, c/o Dipartimento di Chimica, Università di Roma "La Sapienza", P.le A. Moro, 5 I00185 Rome, Italy.

${ }^{\mathrm{b}}$ CIRCC Interuniversity Consortium Chemical Reactivity and Catalysis, Via Celso Ulpiani 27, 70126 Bari, Italy.
}

Instruments and general methods

Dependence of $\boldsymbol{k}_{(\mathrm{obs})}$ for the decay of $\left[(\mathrm{N} 4 \mathrm{Py}) \mathrm{Fe}^{\mathrm{IV}}(\mathrm{O})\right]^{2+}$ on the concentration of hydrocarbons, alcohols, benzaldehyde, ethers and amides.

Dependence of $\boldsymbol{k}_{(\mathrm{obs})}$ for the decay of PINO on the concentration of hydrocarbons, alcohols, benzaldehyde, ethers and amides.

Decay of absorbance recorded at $695 \mathrm{~nm}$ in the oxidation of hydrocarbons, alcohols, aldehydes, ethers and amides with $\left[(\mathrm{N} 4 \mathrm{Py}) \mathrm{Fe}^{\mathrm{IV}}(\mathrm{O})\right]^{2+}$ in the absence and in the presence of NHPI.

Correlations between $\log k_{2}$ for the reaction of hydrocarbons with $\left[(\mathrm{N} 4 \mathrm{Py}) \mathrm{Fe}^{\mathrm{IV}}=\mathrm{O}\right]^{2+}$ and with PINO with $\mathrm{C}-\mathrm{H}$ bond dissociation energies (BDEC-H).

Hammett plots for the reaction of para-substituted toluenes with $\left[(\mathrm{N} 4 \mathrm{Py}) \mathrm{Fe}^{\mathrm{IV}}=\mathrm{O}\right]^{2+}$ and with PINO.

GC analysis of the competitive intermolecular oxidation of aliphatic alcohols/ alkylaromatics mixtures $(190 \mathrm{mM})$ promoted by $\left[(\mathrm{N} 4 \mathrm{Py}) \mathrm{Fe}^{\mathrm{IV}}=\mathrm{O}\right]^{2+}$ and $\left[(\mathrm{Bn}-\mathrm{TPEN}) \mathrm{Fe}^{\mathrm{IV}}=\mathrm{O}\right]^{2+}(19 \mathrm{mM})$ in the absence or presence of $20 \mathrm{~mol} \% \mathrm{NHPI}$ as mediator in $\mathrm{CH}_{3} \mathrm{CN}$. 


\section{Instruments and general methods}

Oxidation products related to the oxidation of all the substrates were identified by comparison of GC retention times and ${ }^{1} \mathrm{H}$ NMR spectra with that of commercially available standard samples or synthesized ones. GC analyses were carried out on gas chromatographs equipped with a capillary methylsilicone column (30 m x $0.25 \mathrm{~mm}$ x $25 \mu \mathrm{m})$ Chrompack CP-Sil 5 CB and a capillary (5\%phenyl)-methylpolysiloxane column $(30 \mathrm{~m} \times 0.25 \mathrm{~mm} \times 25 \mu \mathrm{m}) \mathrm{HP}-5 \mathrm{MS}$ UI. GC-MS analyses were performed with a mass detector (EI at $70 \mathrm{eV}$ ) coupled with a gas chromatograph equipped with a melted silica capillary column $(30 \mathrm{~m} \times 0.2 \mathrm{~mm} \times 25 \mu \mathrm{m})$ covered with a methylsilicone film (5\% phenylsilicone, OV5). NMR spectra were recorded on a BrukerDPX300 spectrometer and were internally referenced to the residual proton solvent signal. UV Vis measurements were performed on a diode array spectrophotometer. For the fast reaction the instrument was equipped with a rapid mixing accessory. 
Dependence of $\boldsymbol{k}_{(\mathrm{obs})}$ for the decay of $\left[(\mathrm{N} 4 \mathrm{Py}) \mathrm{Fe}^{\mathrm{IV}}(\mathrm{O})\right]^{2+}$ on the concentration of hydrocarbons, alcohols, aldehydes, ethers and amides.

Hydrocarbons

\begin{tabular}{cll}
\hline [Toluene] $(\mathbf{M})$ & $\boldsymbol{k}_{\text {(obs) }}\left(\mathbf{s}^{-1}\right)$ & Std. Error \\
\hline 0.800 & $3.05 \times 10^{-4}$ & $1.13 \times 10^{-5}$ \\
1.000 & $4.02 \times 10^{-4}$ & $1.49 \times 10^{-5}$ \\
1.200 & $5.17 \times 10^{-4}$ & $1.91 \times 10^{-5}$ \\
1.600 & $7.71 \times 10^{-4}$ & $2.85 \times 10^{-5}$
\end{tabular}

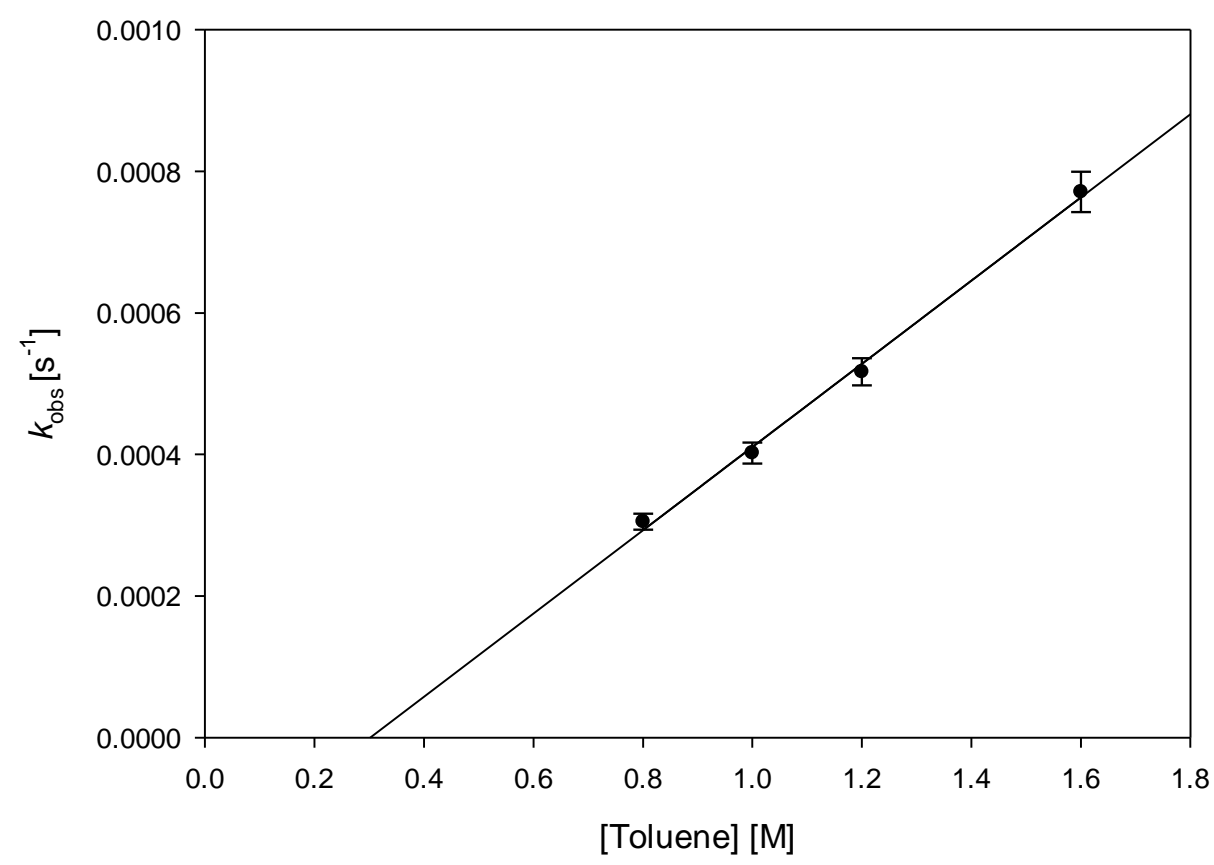

Figure S1. Dependence of pseudo-first order rate constants $\left(k_{\mathrm{obs}}\right)$ for the decay of $\left[(\mathrm{N} 4 \mathrm{Py}) \mathrm{Fe}^{\mathrm{IV}}(\mathrm{O})\right]^{2+}$ on the concentrations of Toluene in $\mathrm{CH}_{3} \mathrm{CN}$ at $25^{\circ} \mathrm{C}\left(\mathrm{r}^{2}=0.997\right)$. 


\begin{tabular}{cll}
\hline$[\boldsymbol{p}$-Xilene $](\mathbf{M})$ & $\boldsymbol{k}_{(\mathrm{obs})}\left(\mathbf{s}^{-1}\right)$ & Std. Error \\
\hline 0.100 & $2.89 \times 10^{-4}$ & $2.57 \times 10^{-4}$ \\
0.200 & $2.52 \times 10^{-4}$ & $4.65 \times 10^{-4}$ \\
0.300 & $6.61 \times 10^{-4}$ & $6.28 \times 10^{-4}$ \\
0.500 & $1.06 \times 10^{-3}$ & $9.34 \times 10^{-4}$
\end{tabular}

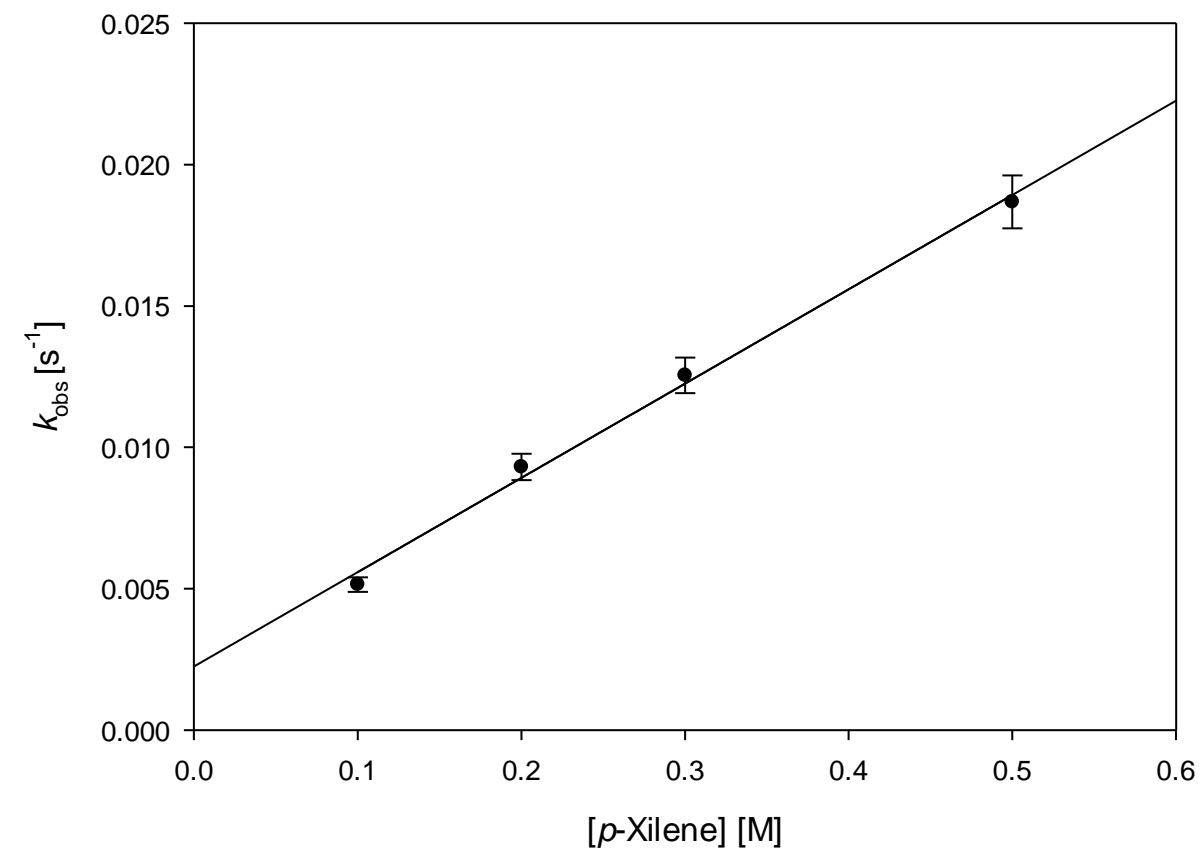

Figure S2. Dependence of pseudo-first order rate constants $\left(k_{\mathrm{obs}}\right)$ for the decay of $\left[(\mathrm{N} 4 \mathrm{Py}) \mathrm{Fe}^{\mathrm{IV}}(\mathrm{O})\right]^{2+}$ on the concentrations of $p$-Xilene in $\mathrm{CH}_{3} \mathrm{CN}$ at $25^{\circ} \mathrm{C}\left(\mathrm{r}^{2}=0.995\right)$. 


\begin{tabular}{cll}
\hline $\begin{array}{c}\text { [1-methoxy-4-methylbenzene }] \\
(\mathbf{M})\end{array}$ & $\boldsymbol{k}_{(\mathrm{obs})}\left(\mathbf{s}^{-\mathbf{1}}\right)$ & Std. Error \\
\hline 0.100 & $1.39 \times 10^{-4}$ & $5.55 \times 10^{-6}$ \\
0.150 & $2.85 \times 10^{-4}$ & $1.14 \times 10^{-5}$ \\
0.250 & $5.97 \times 10^{-4}$ & $2.39 \times 10^{-5}$ \\
0.300 & $7.54 \times 10^{-4}$ & $3.02 \times 10^{-5}$ \\
0.350 & $8.66 \times 10^{-4}$ & $3.46 \times 10^{-5}$
\end{tabular}

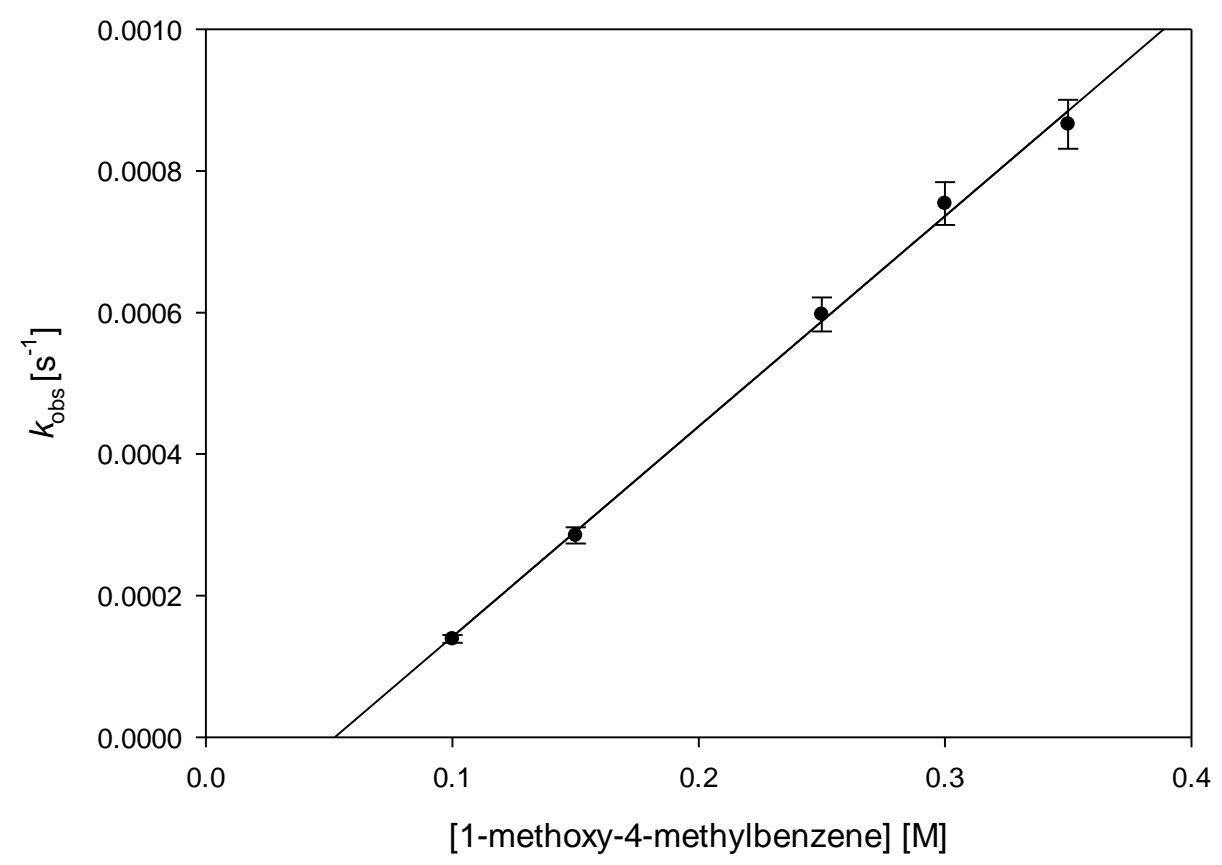

Figure S3. Dependence of pseudo-first order rate constants $\left(k_{\mathrm{obs}}\right)$ for the decay of $\left[(\mathrm{N} 4 \mathrm{Py}) \mathrm{Fe}^{\mathrm{IV}}(\mathrm{O})\right]^{2+}$ on the concentrations of 1-methoxy-4-methylbenzene in $\mathrm{CH}_{3} \mathrm{CN}$ at $25{ }^{\circ} \mathrm{C}$ $\left(r^{2}=0.998\right)$. 


\begin{tabular}{cll}
\hline$[\mathbf{1}-(\mathbf{p}-$ tolyl)ethanone $](\mathbf{M})$ & $\boldsymbol{k}_{(\mathbf{o b s})}\left(\mathbf{s}^{\mathbf{- 1}}\right)$ & Std. Error \\
\hline 0.400 & $1.82 \times 10^{-4}$ & $1.60 \times 10^{-5}$ \\
0.500 & $2.17 \times 10^{-4}$ & $1.09 \times 10^{-5}$ \\
0.700 & $3.14 \times 10^{-4}$ & $3.00 \times 10^{-6}$ \\
0.800 & $3.58 \times 10^{-4}$ & $5.00 \times 10^{-6}$
\end{tabular}

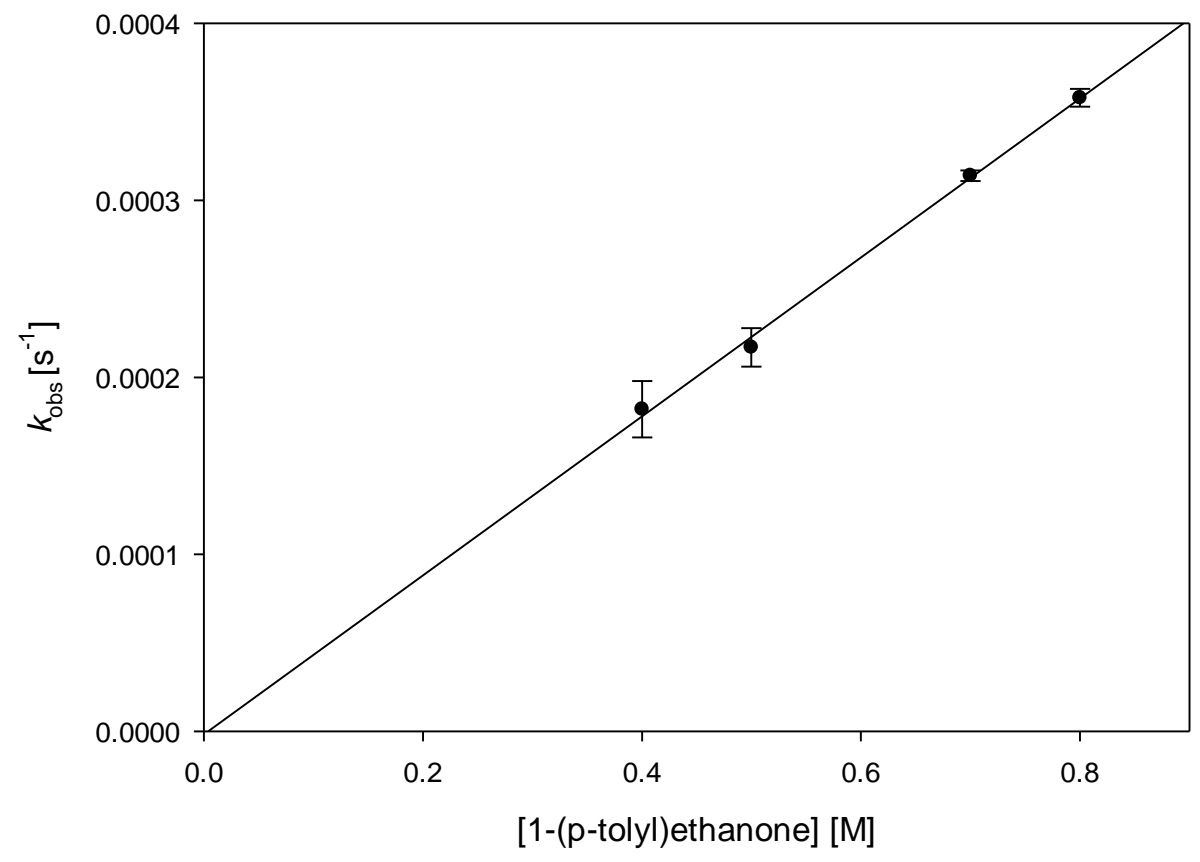

Figure S4. Dependence of pseudo-first order rate constants $\left(k_{\mathrm{obs}}\right)$ for the decay of $\left[(\mathrm{N} 4 \mathrm{Py}) \mathrm{Fe}^{\mathrm{IV}}(\mathrm{O})\right]^{2+}$ on the concentrations of 1-(p-tolyl)ethanone in $\mathrm{CH}_{3} \mathrm{CN}$ at $25^{\circ} \mathrm{C}\left(\mathrm{r}^{2}=0.997\right)$. 


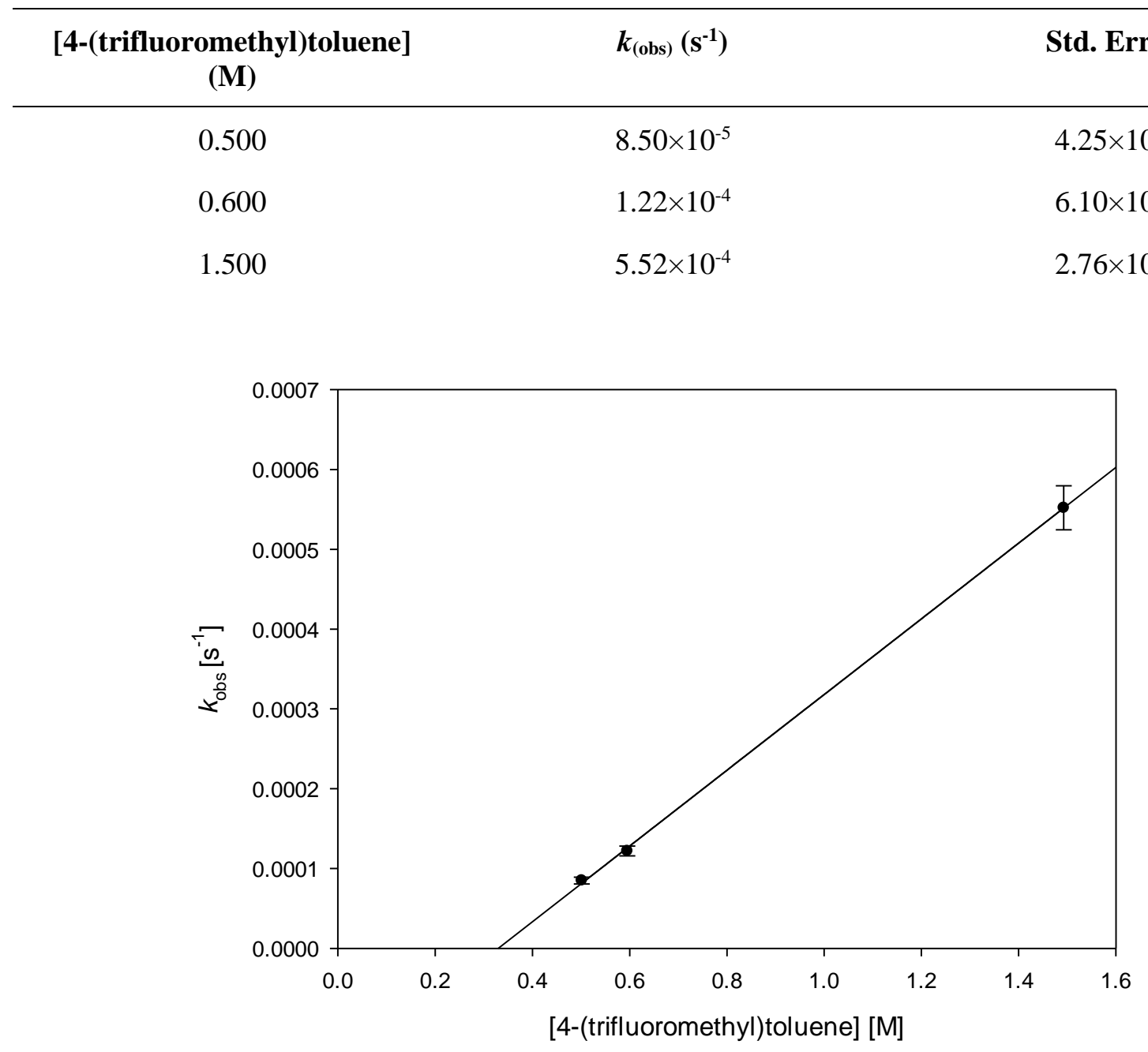

Figure S5. Dependence of pseudo-first order rate constants $\left(k_{\mathrm{obs}}\right)$ for the decay of $\left[(\mathrm{N} 4 \mathrm{Py}) \mathrm{Fe}^{\mathrm{IV}}(\mathrm{O})\right]^{2+}$ on the concentrations of 4-(trifluoromethyl)toluene in $\mathrm{CH}_{3} \mathrm{CN}$ at $25{ }^{\circ} \mathrm{C}$ $\left(r^{2}=0.999\right)$. 


\begin{tabular}{cll}
\hline [4-nitrotoluene] $(\mathbf{M})$ & $\boldsymbol{k}_{(\mathbf{o b s})}\left(\mathbf{s}^{\mathbf{- 1}}\right)$ & Std. Error \\
\hline 0.800 & $1.33 \times 10^{-4}$ & $4.66 \times 10^{-6}$ \\
1.000 & $1.93 \times 10^{-4}$ & $6.76 \times 10^{-6}$ \\
1.300 & $2.88 \times 10^{-4}$ & $1.01 \times 10^{-5}$ \\
1.500 & $3.25 \times 10^{-4}$ & $1.14 \times 10^{-5}$
\end{tabular}

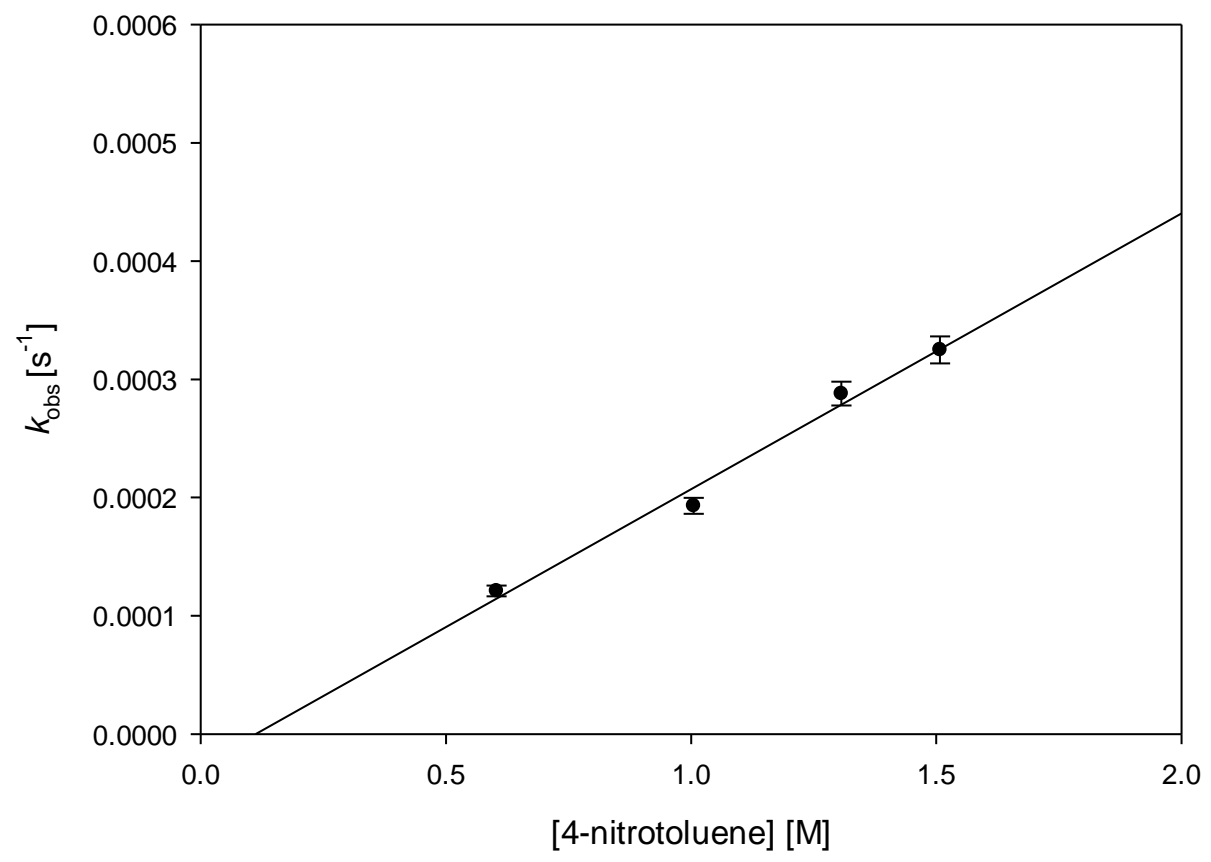

Figure S6. Dependence of pseudo-first order rate constants $\left(k_{\mathrm{obs}}\right)$ for the decay of $\left[(\mathrm{N} 4 \mathrm{Py}) \mathrm{Fe}^{\mathrm{IV}}(\mathrm{O})\right]^{2+}$ on the concentrations of 4-nitrotoluene in $\mathrm{CH}_{3} \mathrm{CN}$ at $25{ }^{\circ} \mathrm{C}\left(\mathrm{r}^{2}=0.991\right)$. 


\begin{tabular}{cll}
\hline [Diphenylmethane] $(\mathbf{M})$ & $\boldsymbol{k}_{\text {(obs) }}\left(\mathbf{s}^{-1}\right)$ & Std. Error \\
\hline 0.020 & $4.00 \times 10^{-4}$ & $8.00 \times 10^{-6}$ \\
0.030 & $6.00 \times 10^{-4}$ & $1.20 \times 10^{-5}$ \\
0.040 & $8.00 \times 10^{-4}$ & $1.60 \times 10^{-5}$ \\
0.050 & $1.00 \times 10^{-3}$ & $2.00 \times 10^{-5}$ \\
0.060 & $1.20 \times 10^{-3}$ & $2.40 \times 10^{-5}$
\end{tabular}

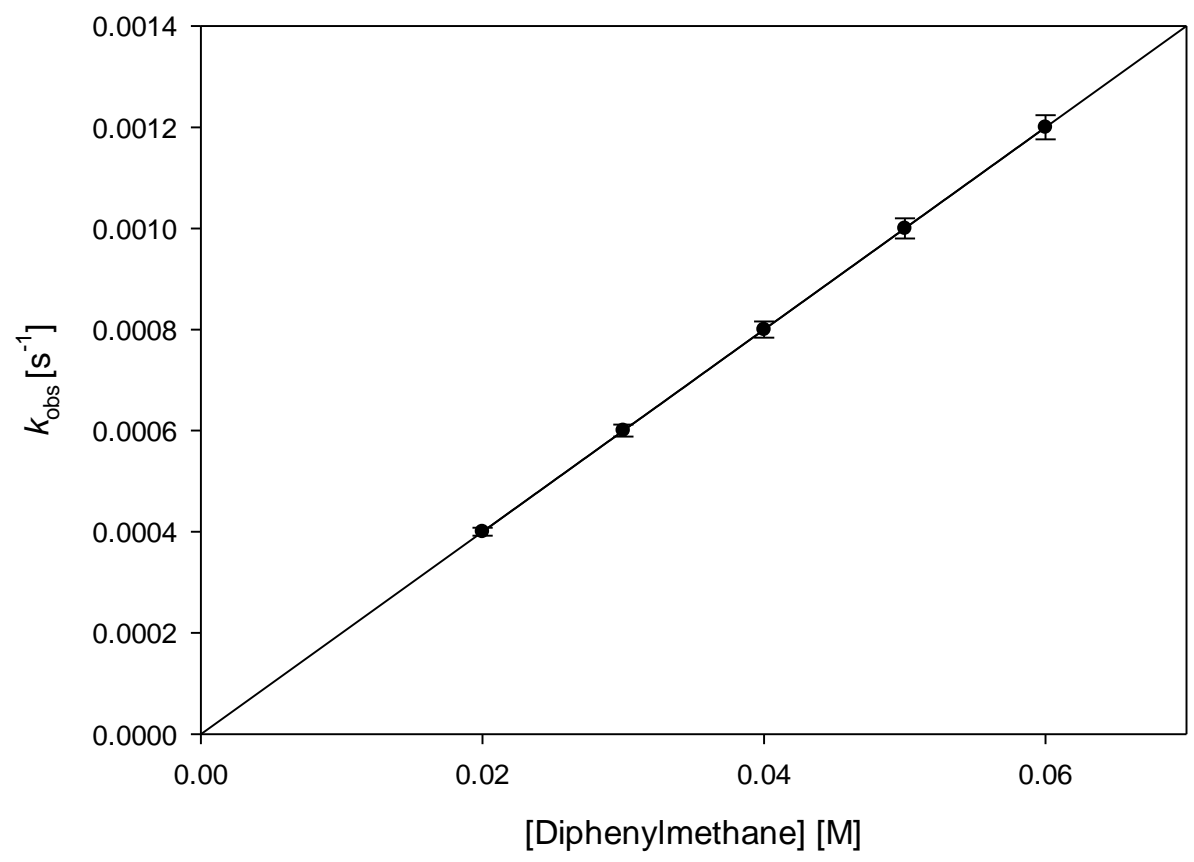

Figure S7. Dependence of pseudo-first order rate constants $\left(k_{\mathrm{obs}}\right)$ for the decay of $\left[(\mathrm{N} 4 \mathrm{Py}) \mathrm{Fe}^{\mathrm{IV}}(\mathrm{O})\right]^{2+}$ on the concentrations of Diphenylmethane in $\mathrm{CH}_{3} \mathrm{CN}$ at $25^{\circ} \mathrm{C}\left(\mathrm{r}^{2}=1\right)$. 


\begin{tabular}{cll}
\hline [1-butanol] $(\mathbf{M})$ & $\boldsymbol{k}_{(\mathbf{o b s})}\left(\mathbf{s}^{-\mathbf{1}}\right)$ & Std. Error \\
\hline 0.300 & $9.40 \times 10^{-5}$ & $4.32 \times 10^{-6}$ \\
0.400 & $1.49 \times 10^{-4}$ & $6.87 \times 10^{-6}$ \\
0.500 & $1.79 \times 10^{-4}$ & $8.23 \times 10^{-6}$ \\
0.600 & $2.55 \times 10^{-4}$ & $1.17 \times 10^{-5}$
\end{tabular}

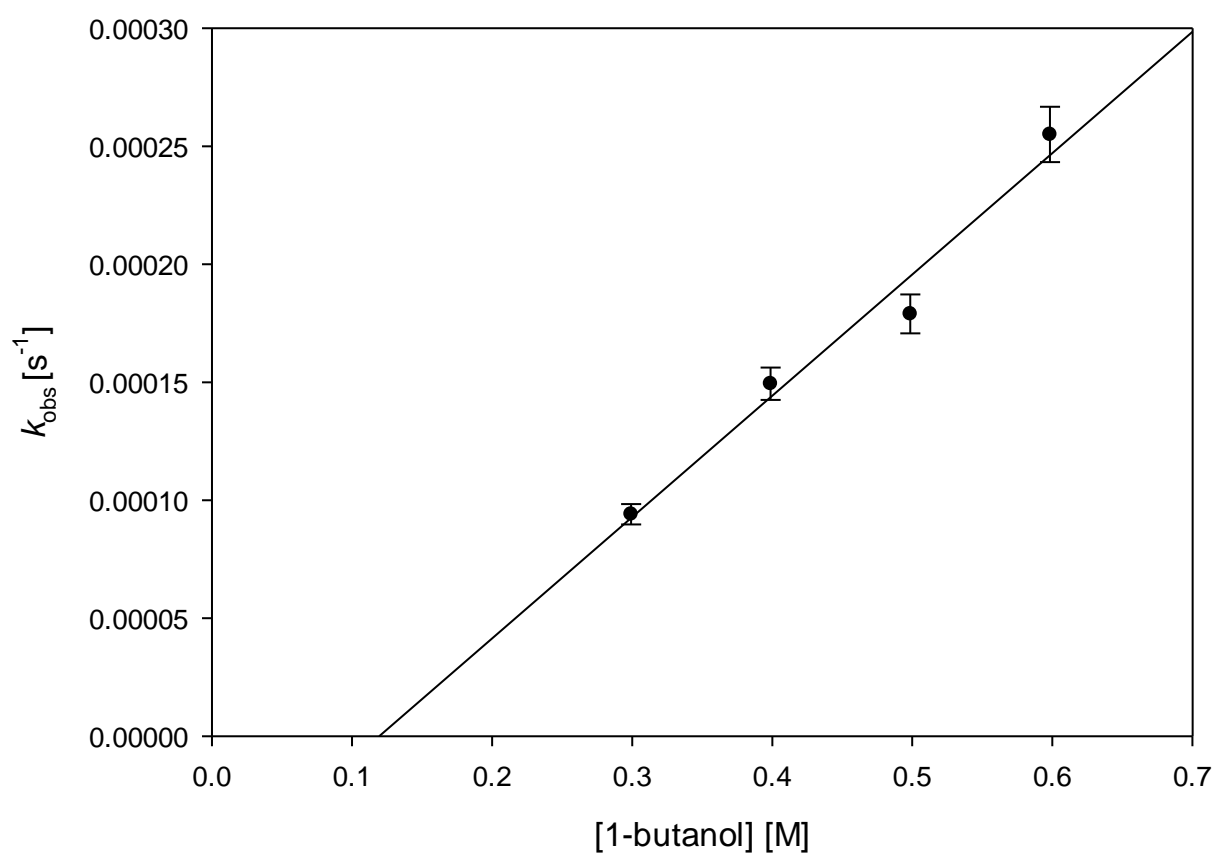

Figure S8. Dependence of pseudo-first order rate constants $\left(k_{\mathrm{obs}}\right)$ for the decay of $\left[(\mathrm{N} 4 \mathrm{Py}) \mathrm{Fe}^{\mathrm{IV}}(\mathrm{O})\right]^{2+}$ on the concentrations of 1-butanol in $\mathrm{CH}_{3} \mathrm{CN}$ at $25{ }^{\circ} \mathrm{C}\left(\mathrm{r}^{2}=0.973\right)$. 


\begin{tabular}{cll}
\hline [1-decanol] $(\mathbf{M})$ & $\boldsymbol{k}_{(\mathbf{o b s})}\left(\mathbf{s}^{-\mathbf{1}}\right)$ & Std. Error \\
\hline 0.050 & $5.95 \times 10^{-7}$ & $2.12 \times 10^{-8}$ \\
0.101 & $1.10 \times 10^{-5}$ & $4.07 \times 10^{-7}$ \\
0.201 & $5.40 \times 10^{-5}$ & $2.16 \times 10^{-6}$ \\
0.302 & $1.06 \times 10^{-4}$ & $4.24 \times 10^{-6}$
\end{tabular}

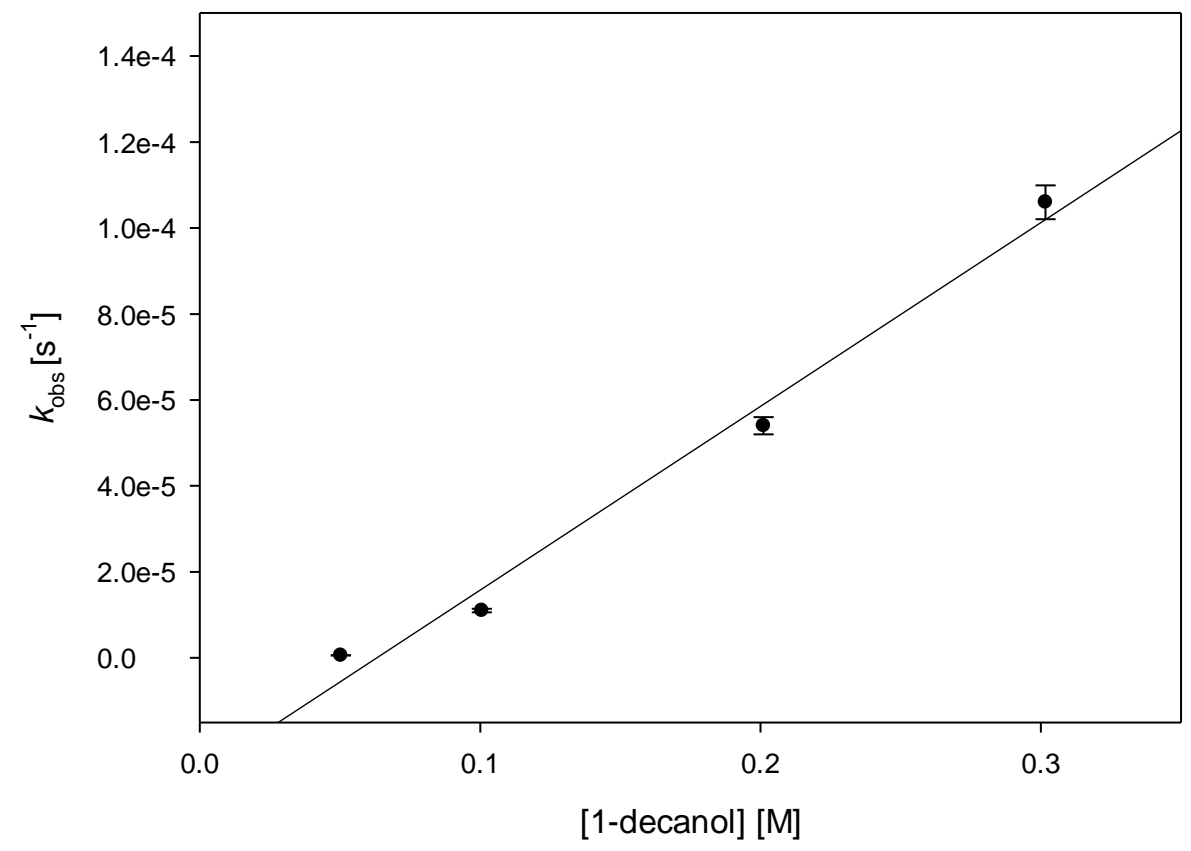

Figure S9. Dependence of pseudo-first order rate constants $\left(k_{\mathrm{obs}}\right)$ for the decay of $\left[(\mathrm{N} 4 \mathrm{Py}) \mathrm{Fe}^{\mathrm{IV}}(\mathrm{O})\right]^{2+}$ on the concentrations of 1-decanol in $\mathrm{CH}_{3} \mathrm{CN}$ at $25^{\circ} \mathrm{C}\left(\mathrm{r}^{2}=0.985\right)$. 


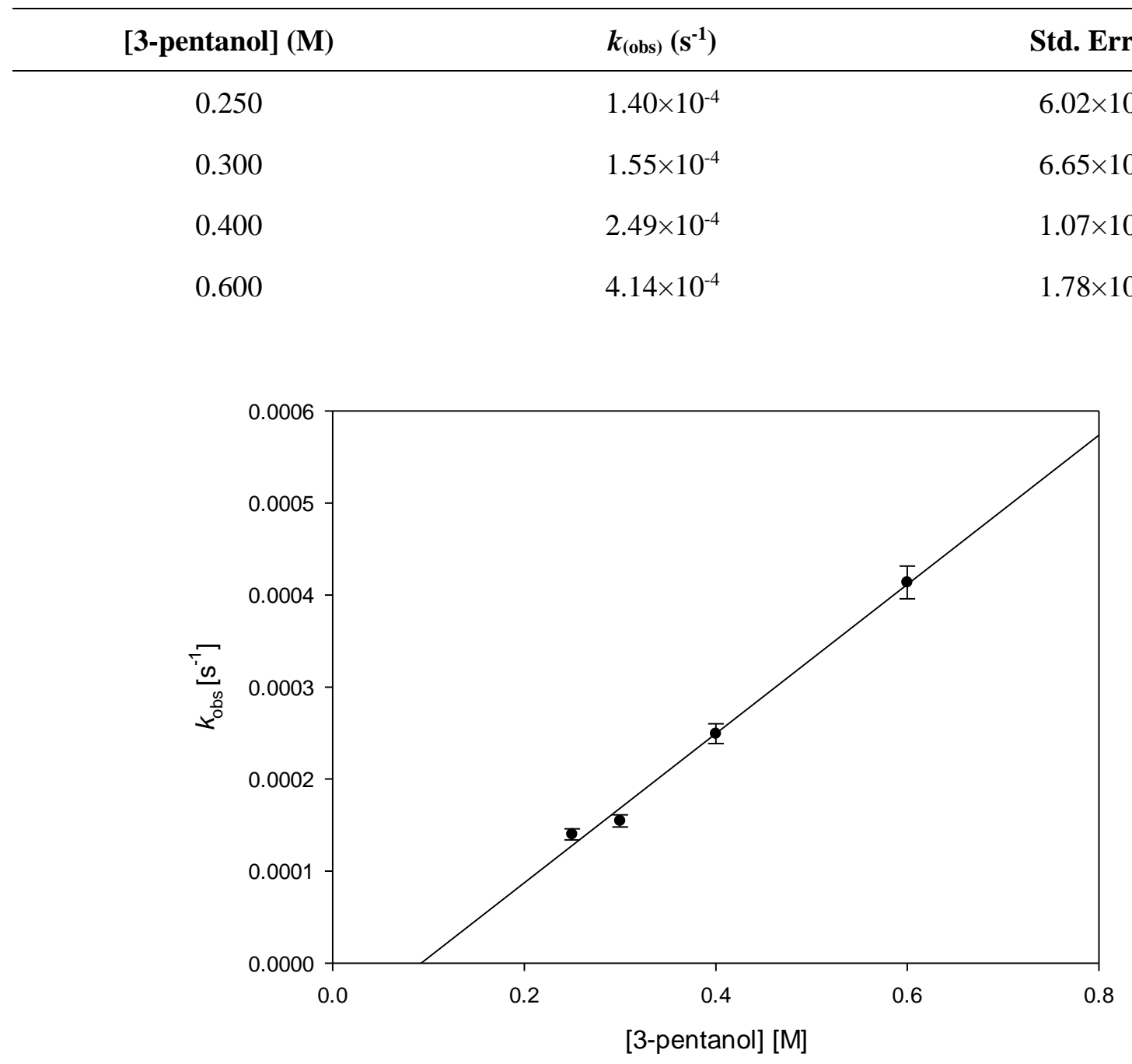

Figure S10. Dependence of pseudo-first order rate constants $\left(k_{\mathrm{obs}}\right)$ for the decay of $\left[(\mathrm{N} 4 \mathrm{Py}) \mathrm{Fe}^{\mathrm{IV}}(\mathrm{O})\right]^{2+}$ on the concentrations of 3-pentanol in $\mathrm{CH}_{3} \mathrm{CN}$ at $25{ }^{\circ} \mathrm{C}\left(\mathrm{r}^{2}=0.993\right)$. 


\begin{tabular}{cll}
\hline [Cyclopentanol] $(\mathbf{M})$ & $\boldsymbol{k}_{(\mathbf{o b s})}\left(\mathbf{s}^{-1}\right)$ & Std. Error \\
\hline 0.200 & $1.09 \times 10^{-4}$ & $3.27 \times 10^{-6}$ \\
0.247 & $1.80 \times 10^{-4}$ & $5.40 \times 10^{-6}$ \\
0.349 & $2.35 \times 10^{-4}$ & $7.05 \times 10^{-6}$ \\
0.401 & $3.34 \times 10^{-4}$ & $1.00 \times 10^{-5}$
\end{tabular}

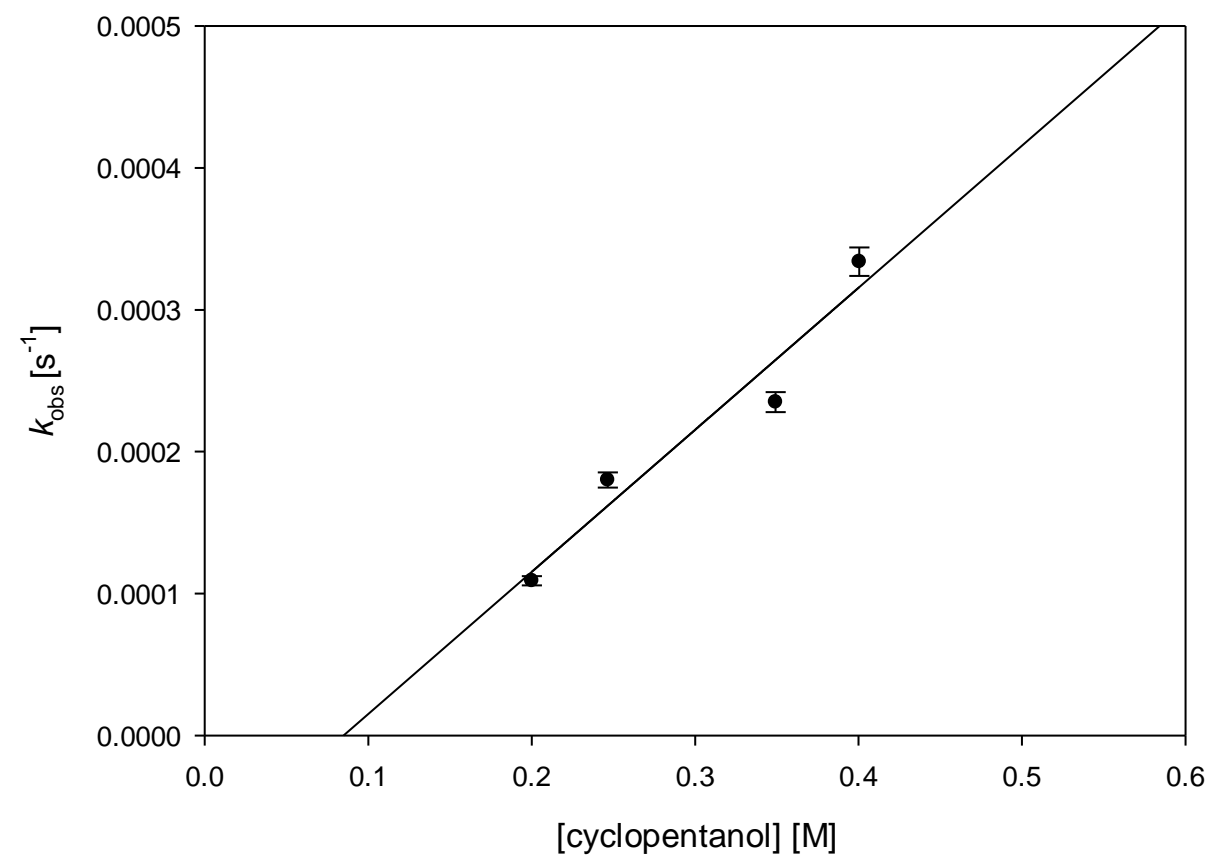

Figure S11. Dependence of pseudo-first order rate constants $\left(k_{\mathrm{obs}}\right)$ for the decay of $\left[(\mathrm{N} 4 \mathrm{Py}) \mathrm{Fe}^{\mathrm{IV}}(\mathrm{O})\right]^{2+}$ on the concentrations of cyclopentanol in $\mathrm{CH}_{3} \mathrm{CN}$ at $25^{\circ} \mathrm{C}\left(\mathrm{r}^{2}=0.942\right)$. 


\begin{tabular}{cll}
\hline [Cyclohexanol] $(\mathbf{M})$ & $\boldsymbol{k}_{\text {(obs) }}\left(\mathbf{s}^{-1}\right)$ & Std. Error \\
\hline 0.100 & $1.10 \times 10^{-4}$ & $2.21 \times 10^{-6}$ \\
0.200 & $2.29 \times 10^{-4}$ & $4.58 \times 10^{-6}$ \\
0.300 & $3.47 \times 10^{-4}$ & $6.93 \times 10^{-6}$ \\
0.400 & $4.98 \times 10^{-4}$ & $9.96 \times 10^{-6}$ \\
0.500 & $6.11 \times 10^{-4}$ & $1.22 \times 10^{-5}$ \\
0.600 & $6.84 \times 10^{-4}$ & $1.37 \times 10^{-5}$
\end{tabular}

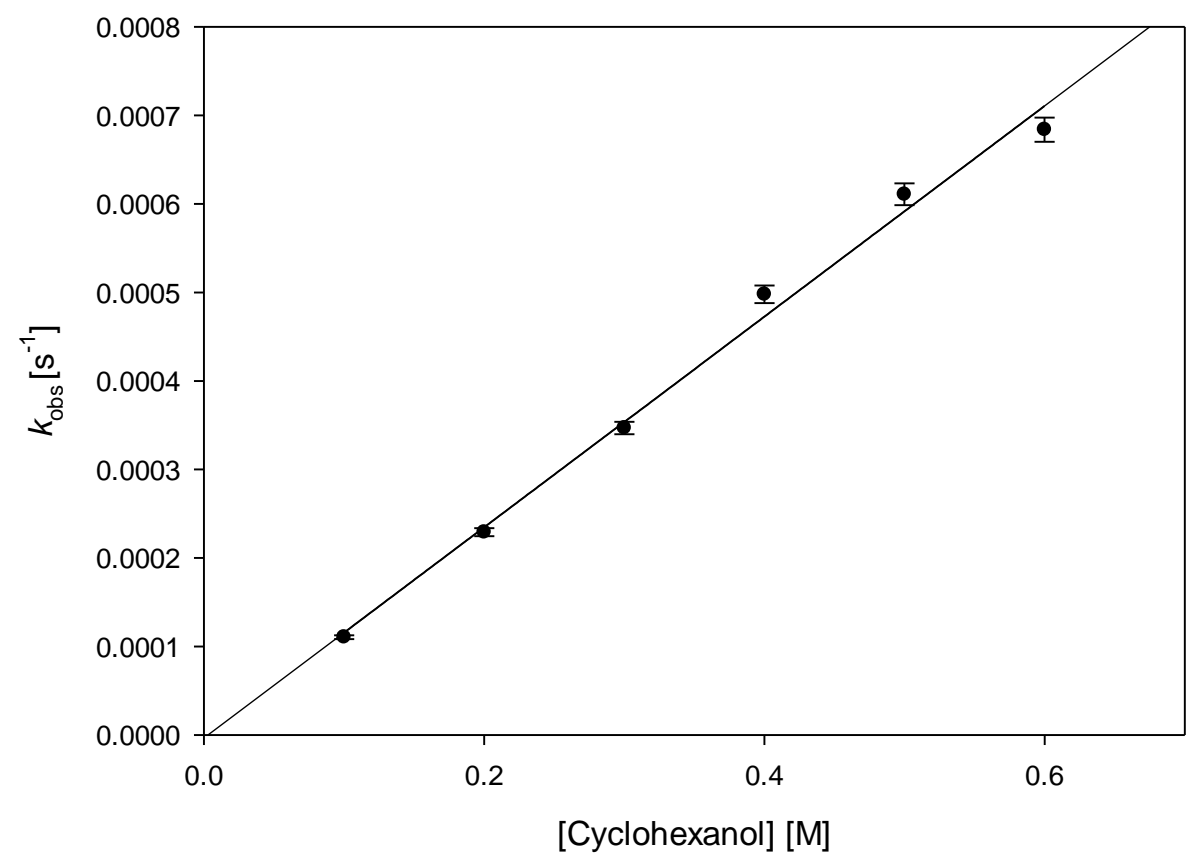

Figure S12. Dependence of pseudo-first order rate constants $\left(k_{\mathrm{obs}}\right)$ for the decay of $\left[(\mathrm{N} 4 \mathrm{Py}) \mathrm{Fe}^{\mathrm{IV}}(\mathrm{O})\right]^{2+}$ on the concentrations of cyclohexanol in $\mathrm{CH}_{3} \mathrm{CN}$ at $25^{\circ} \mathrm{C}\left(\mathrm{r}^{2}=0.993\right)$. 


\begin{tabular}{ccc}
\hline [Benzyl alcohol] $(\mathbf{M})$ & $\boldsymbol{k}_{(\mathbf{o b s})}\left(\mathbf{s}^{-\mathbf{1}}\right)$ & Std. Error \\
\hline 0.020 & $1.80 \times 10^{-3}$ & $4.86 \times 10^{-5}$ \\
0.030 & $3.00 \times 10^{-3}$ & $8.10 \times 10^{-5}$ \\
0.040 & $4.20 \times 10^{-3}$ & $1.13 \times 10^{-4}$ \\
0.060 & $6.80 \times 10^{-4}$ & $1.84 \times 10^{-4}$
\end{tabular}

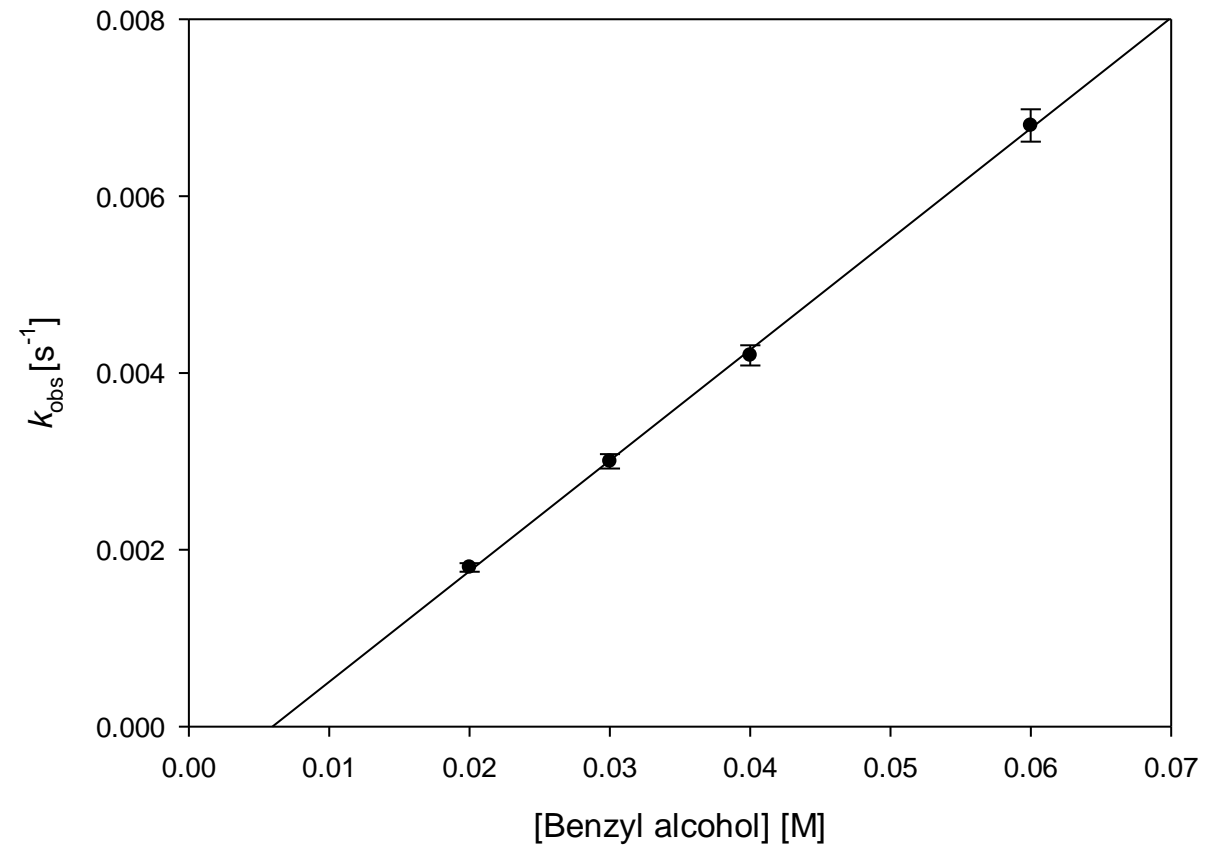

Figure S13. Dependence of pseudo-first order rate constants $\left(k_{\mathrm{obs}}\right)$ for the decay of $\left[(\mathrm{N} 4 \mathrm{Py}) \mathrm{Fe}^{\mathrm{IV}}(\mathrm{O})\right]^{2+}$ on the concentrations of Benzyl alcohol in $\mathrm{CH}_{3} \mathrm{CN}$ at $25^{\circ} \mathrm{C}\left(\mathrm{r}^{2}=0.999\right)$. 


\begin{tabular}{cll}
\hline [Benzaldehyde] $(\mathbf{M})$ & $\boldsymbol{k}_{(\text {obs })}\left(\mathbf{s}^{-1}\right)$ & Std. Error \\
\hline 0.020 & $6.22 \times 10^{-4}$ & $2.68 \times 10^{-5}$ \\
0.030 & $1.15 \times 10^{-3}$ & $4.92 \times 10^{-5}$ \\
0.040 & $1.64 \times 10^{-3}$ & $7.03 \times 10^{-5}$ \\
0.051 & $2.10 \times 10^{-3}$ & $9.01 \times 10^{-5}$ \\
0.060 & $2.42 \times 10^{-3}$ & $1.04 \times 10^{-4}$
\end{tabular}

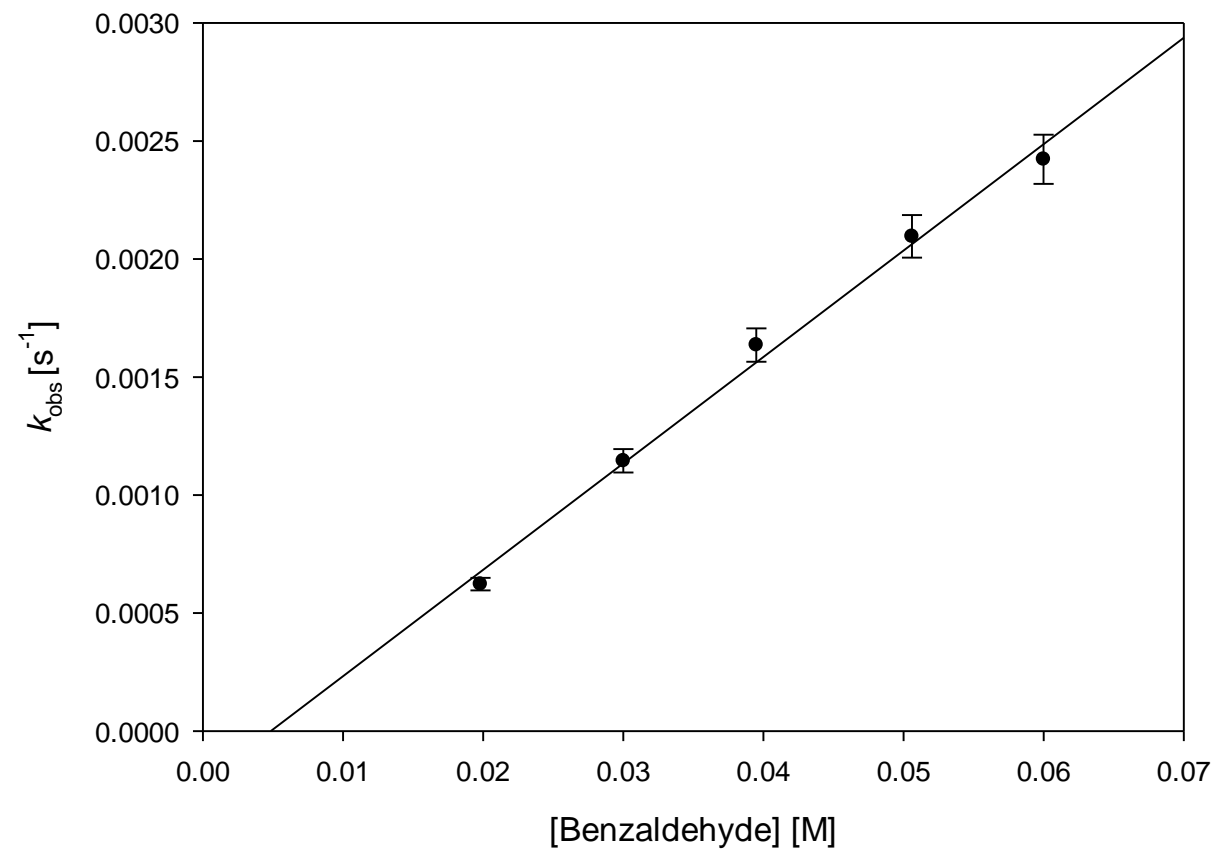

Figure S14. Dependence of pseudo-first order rate constants $\left(k_{\mathrm{obs}}\right)$ for the decay of $\left[(\mathrm{N} 4 \mathrm{Py}) \mathrm{Fe}^{\mathrm{IV}}(\mathrm{O})\right]^{2+}$ on the concentrations of benzaldehyde in $\mathrm{CH}_{3} \mathrm{CN}$ at $25{ }^{\circ} \mathrm{C}\left(\mathrm{r}^{2}=0.994\right)$. 
Ethers

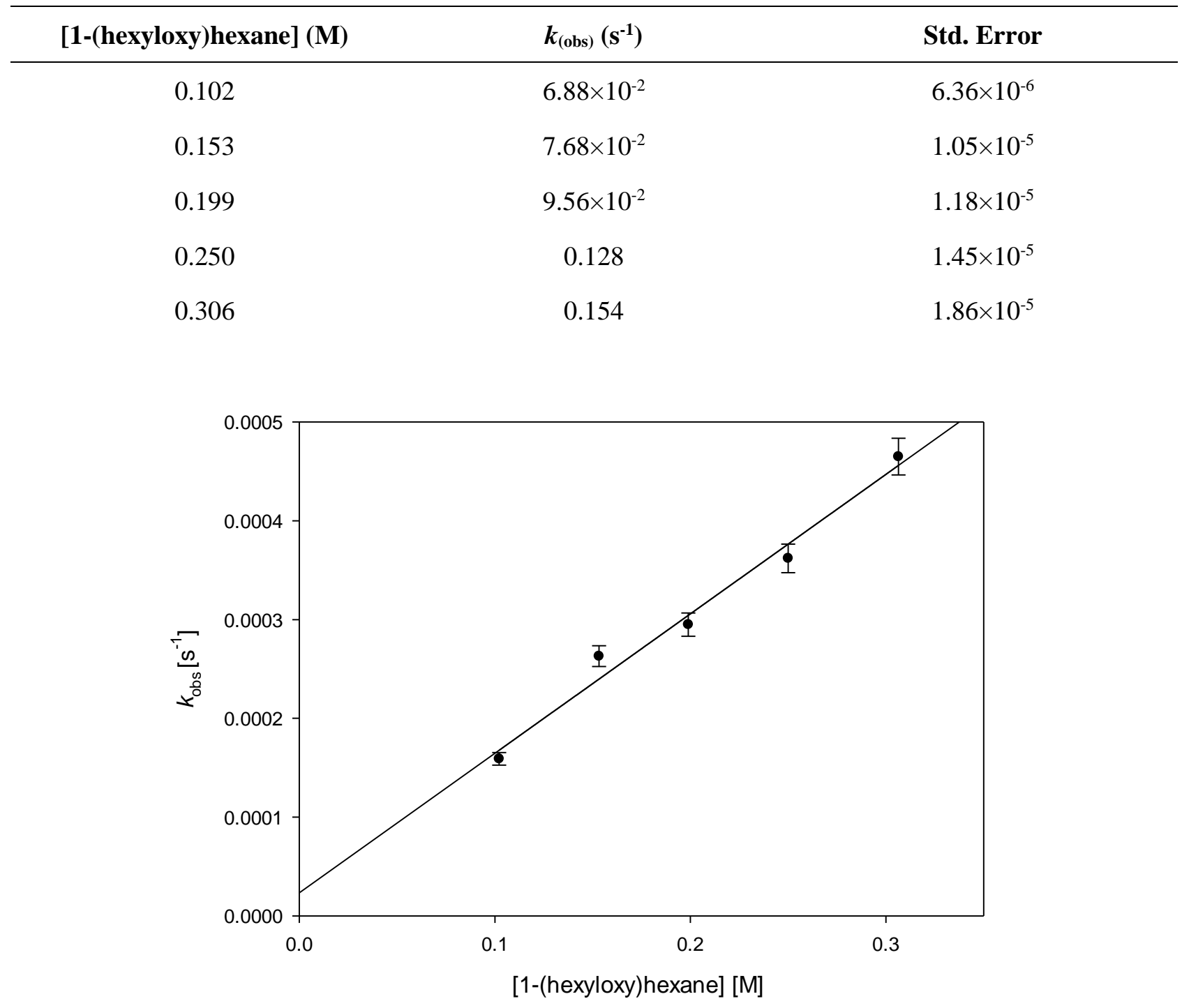

Figure S15. Dependence of pseudo-first order rate constants $\left(k_{\mathrm{obs}}\right)$ for the decay of $\left[(\mathrm{N} 4 \mathrm{Py}) \mathrm{Fe}^{\mathrm{IV}}(\mathrm{O})\right]^{2+}$ on the concentrations of 1-(hexyloxy)hexane in $\mathrm{CH}_{3} \mathrm{CN}$ at $25^{\circ} \mathrm{C}\left(\mathrm{r}^{2}=0.981\right)$. 


\begin{tabular}{cll}
\hline [Tetrahydrofuran] $(\mathbf{M})$ & $\boldsymbol{k}_{\text {(obs) }}\left(\mathbf{s}^{-1}\right)$ & Std. Error \\
\hline 0.100 & $1.37 \times 10^{-4}$ & $3.42 \times 10^{-6}$ \\
0.150 & $2.58 \times 10^{-4}$ & $6.45 \times 10^{-6}$ \\
0.200 & $3.33 \times 10^{-4}$ & $8.34 \times 10^{-6}$ \\
0.250 & $4.50 \times 10^{-4}$ & $1.12 \times 10^{-5}$ \\
0.300 & $4.98 \times 10^{-4}$ & $1.24 \times 10^{-5}$
\end{tabular}

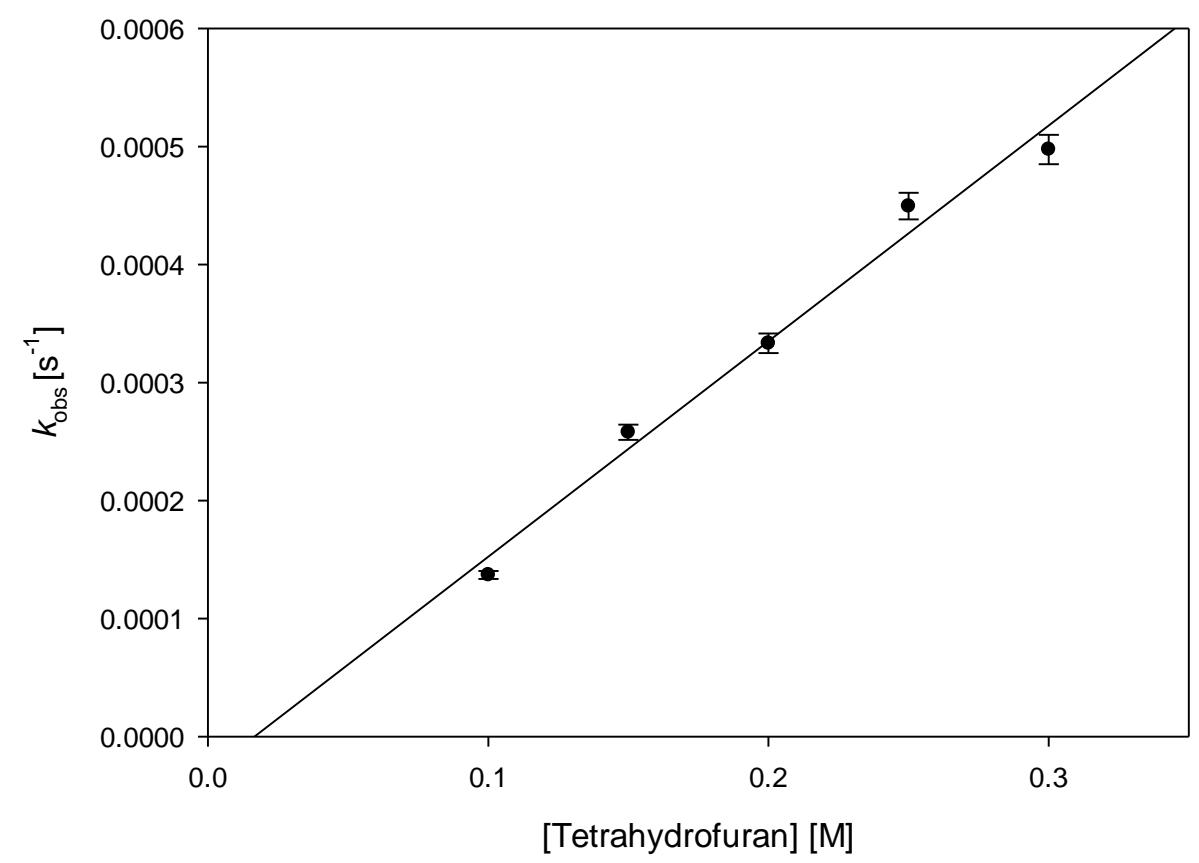

Figure S16. Dependence of pseudo-first order rate constants $\left(k_{\mathrm{obs}}\right)$ for the decay of $\left[(\mathrm{N} 4 \mathrm{Py}) \mathrm{Fe}^{\mathrm{IV}}(\mathrm{O})\right]^{2+}$ on the concentrations of tetrahydrofuran in $\mathrm{CH}_{3} \mathrm{CN}$ at $25{ }^{\circ} \mathrm{C}\left(\mathrm{r}^{2}=0.984\right)$. 


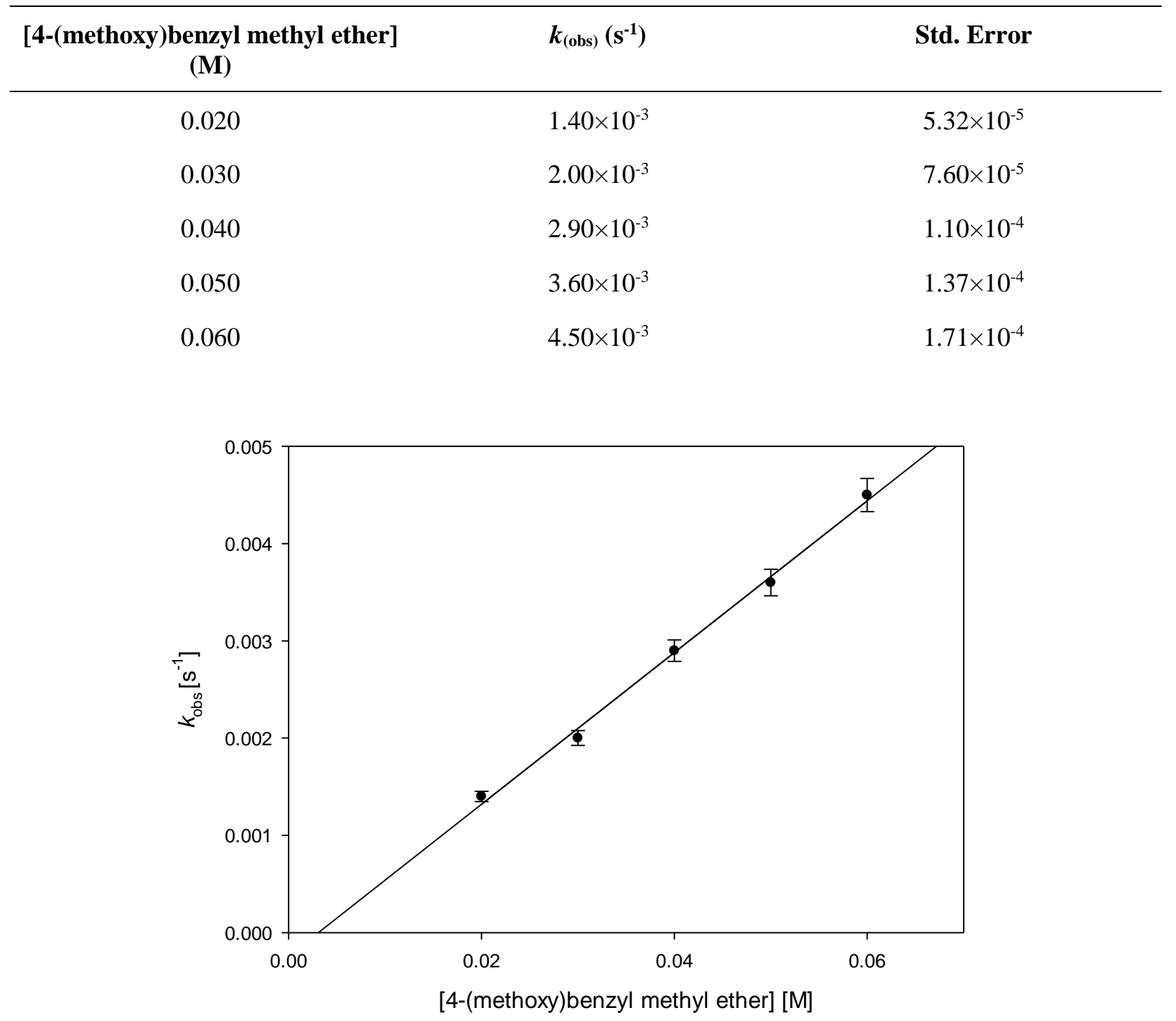

Figure S17. Dependence of pseudo-first order rate constants $\left(k_{\mathrm{obs}}\right)$ for the decay of $\left[(\mathrm{N} 4 \mathrm{Py}) \mathrm{Fe}^{\mathrm{IV}}(\mathrm{O})\right]^{2+}$ on the concentrations of 4-(methoxy)benzyl methyl ether in $\mathrm{CH}_{3} \mathrm{CN}$ at $25{ }^{\circ} \mathrm{C}$ $\left(r^{2}=0.996\right)$. 
Amides

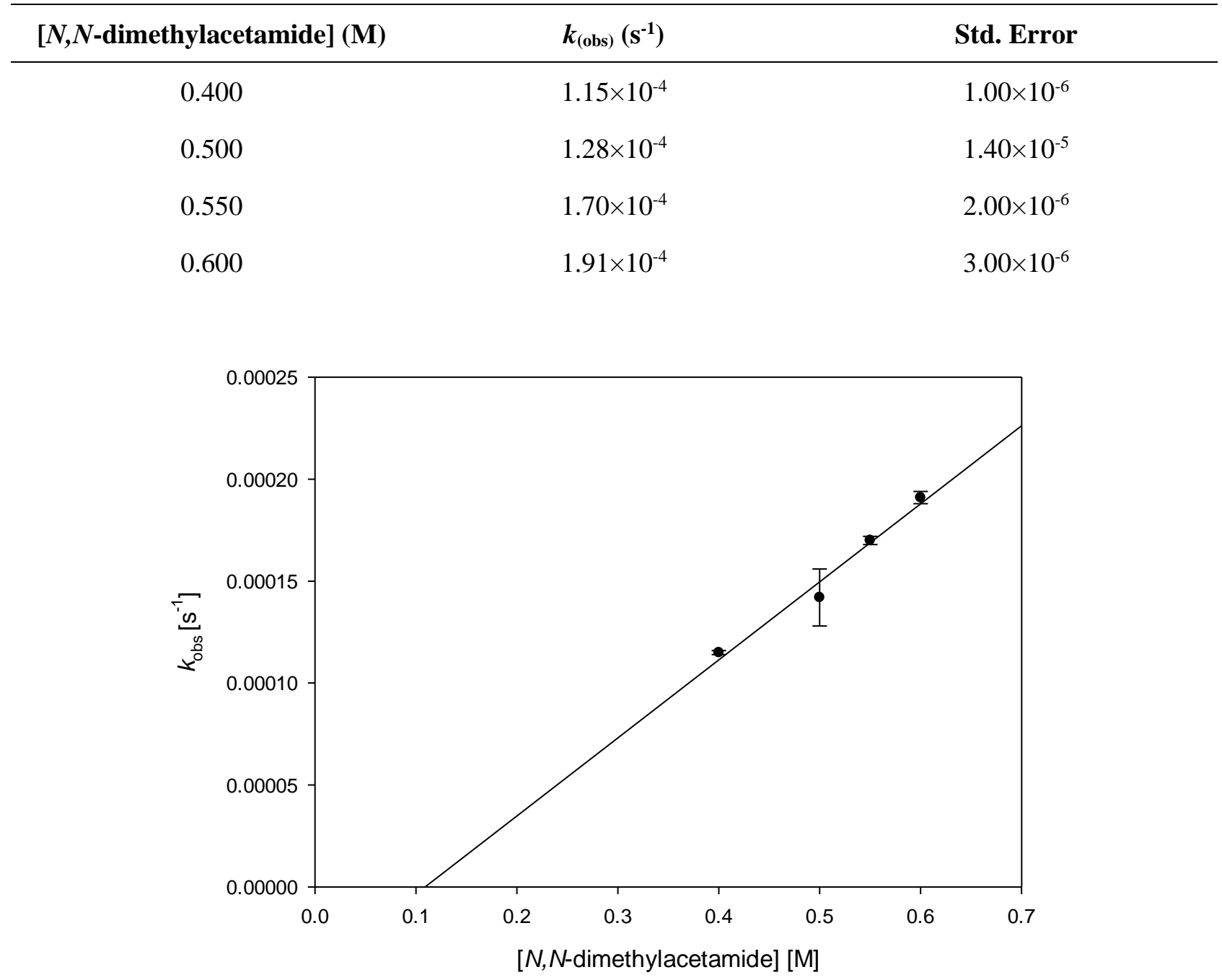

Figure S18. Dependence of pseudo-first order rate constants $\left(k_{\mathrm{obs}}\right)$ for the decay of $\left[(\mathrm{N} 4 \mathrm{Py}) \mathrm{Fe}^{\mathrm{IV}}(\mathrm{O})\right]^{2+}$ on the concentrations of $N, N$-dimethylacetamide in $\mathrm{CH}_{3} \mathrm{CN}$ at $25^{\circ} \mathrm{C}\left(\mathrm{r}^{2}=0.975\right)$. 


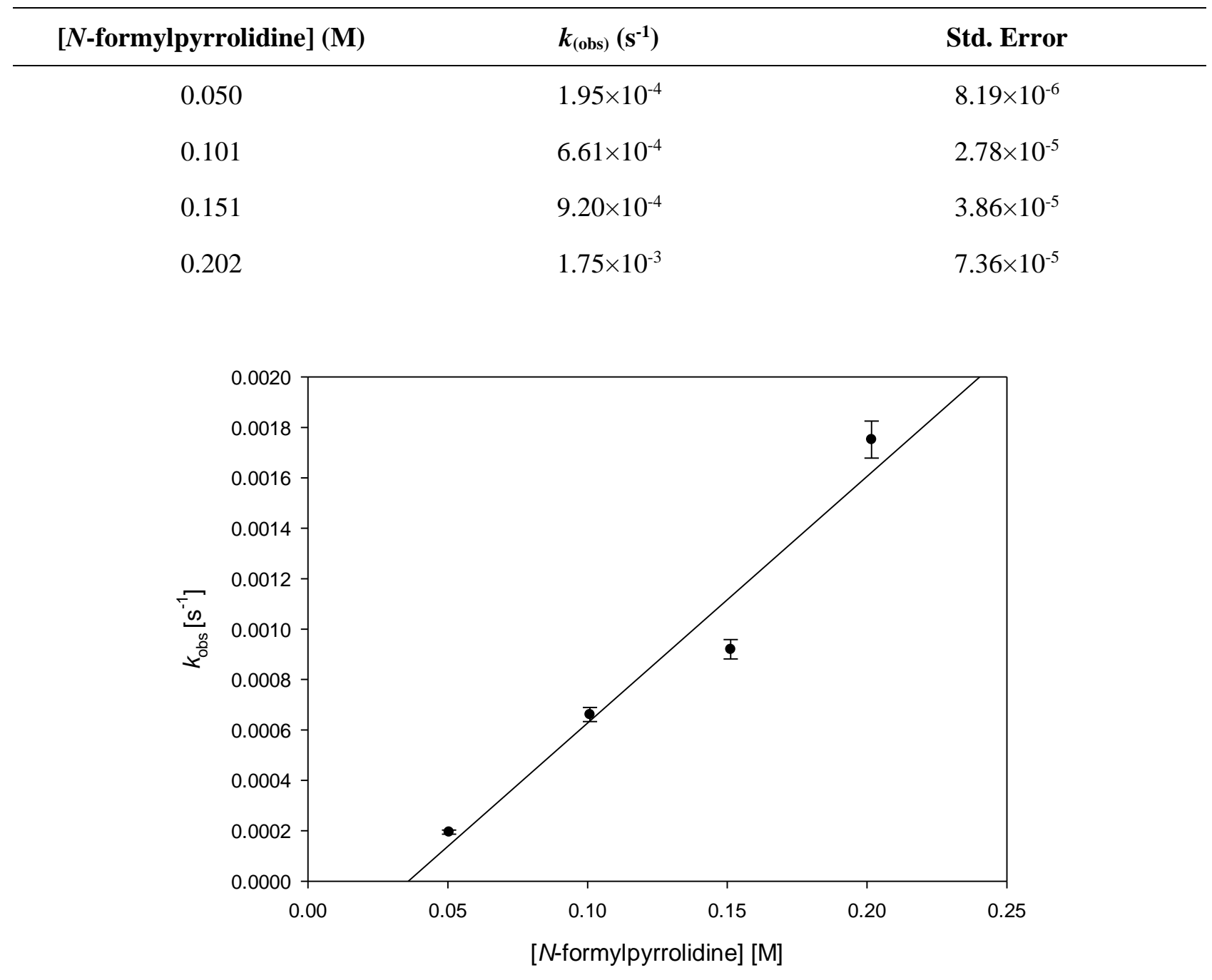

Figure S19. Dependence of pseudo-first order rate constants $\left(k_{\mathrm{obs}}\right)$ for the decay of $\left[(\mathrm{N} 4 \mathrm{Py}) \mathrm{Fe}^{\mathrm{IV}}(\mathrm{O})\right]^{2+}$ on the concentrations of $N$-formylpyrrolidine in $\mathrm{CH}_{3} \mathrm{CN}$ at $25^{\circ} \mathrm{C}\left(\mathrm{r}^{2}=0.950\right)$. 


\begin{tabular}{cll}
\hline$[N$-formylpiperidine $](\mathbf{M})$ & $\boldsymbol{k}_{\text {(obs) }}\left(\mathbf{s}^{-\mathbf{1}}\right)$ & Std. Error \\
\hline 0.253 & $4.09 \times 10^{-4}$ & $1.76 \times 10^{-5}$ \\
0.302 & $5.01 \times 10^{-4}$ & $2.15 \times 10^{-5}$ \\
0.399 & $6.14 \times 10^{-4}$ & $2.64 \times 10^{-5}$ \\
0.487 & $8.28 \times 10^{-4}$ & $3.56 \times 10^{-5}$
\end{tabular}

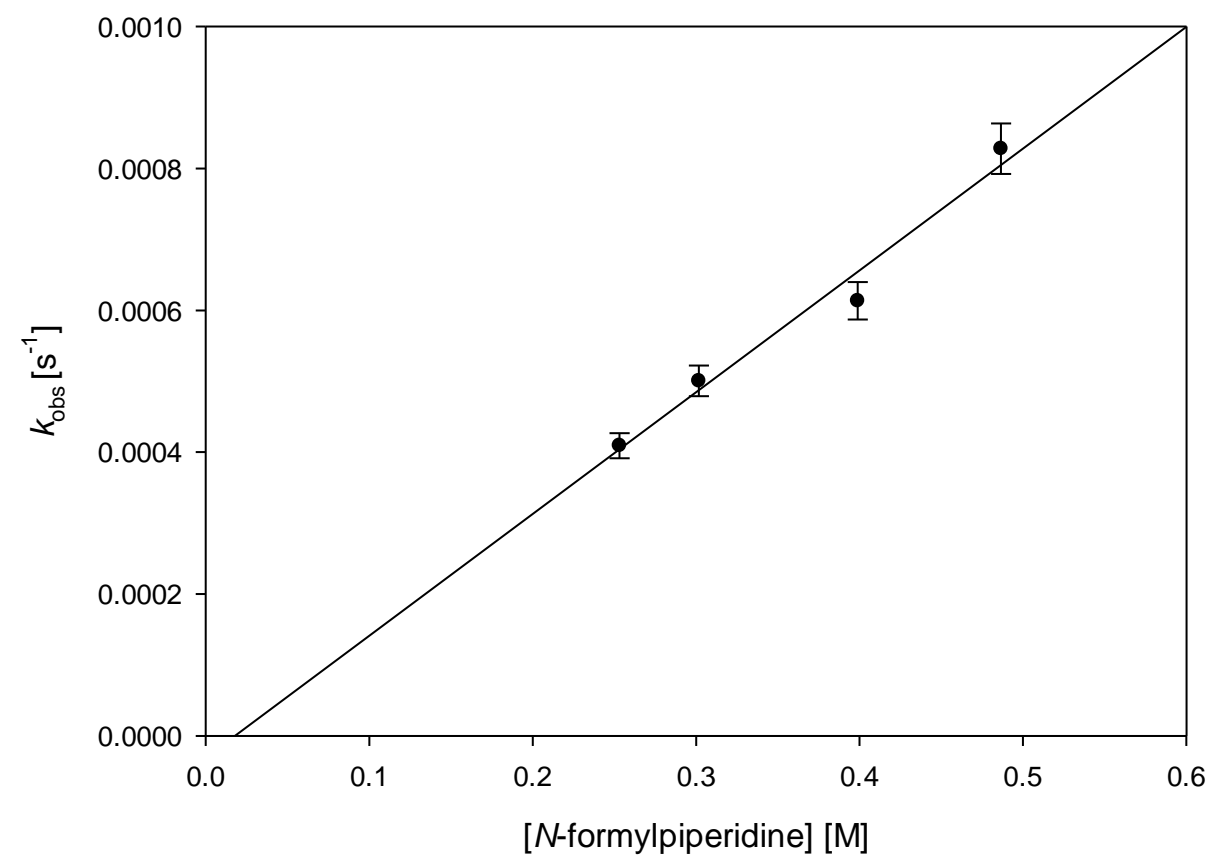

Figure S20. Dependence of pseudo-first order rate constants $\left(k_{\mathrm{obs}}\right)$ for the decay of $\left[(\mathrm{N} 4 \mathrm{Py}) \mathrm{Fe}^{\mathrm{IV}}(\mathrm{O})\right]^{2+}$ on the concentrations of $N$-formylpiperidine in $\mathrm{CH}_{3} \mathrm{CN}$ at $25{ }^{\circ} \mathrm{C}\left(\mathrm{r}^{2}=0.884\right)$. 


\begin{tabular}{cll}
\hline $\begin{array}{c}\text { [N-(4-chlorobenzyl)acetamide] } \\
(\mathbf{M})\end{array}$ & $\boldsymbol{k}_{(\mathrm{obs})}\left(\mathbf{s}^{-1}\right)$ & Std. Error \\
\hline 0.020 & $4.00 \times 10^{-4}$ & $1.84 \times 10^{-5}$ \\
0.030 & $7.00 \times 10^{-4}$ & $3.22 \times 10^{-5}$ \\
0.050 & $1.20 \times 10^{-3}$ & $5.52 \times 10^{-5}$ \\
0.060 & $1.40 \times 10^{-3}$ & $6.44 \times 10^{-5}$
\end{tabular}

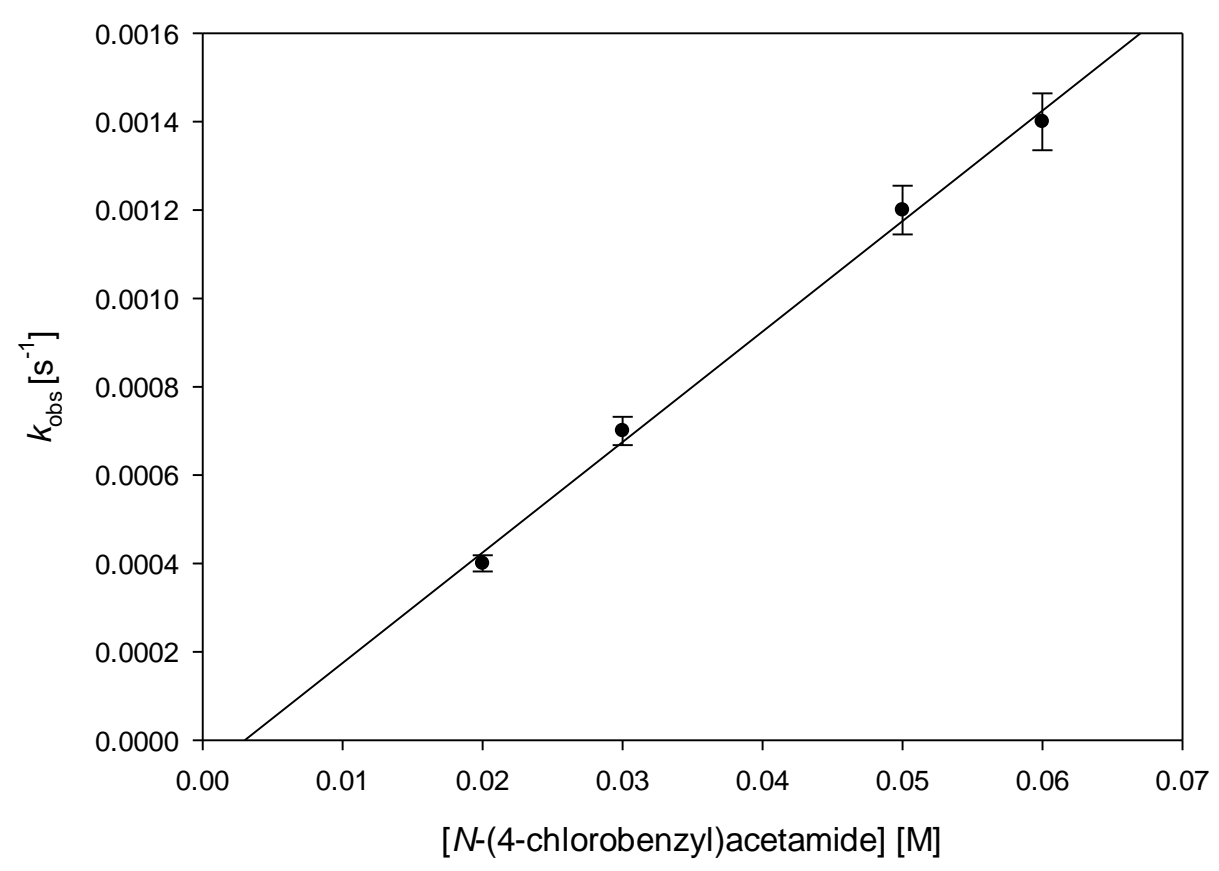

Figure S21. Dependence of pseudo-first order rate constants $\left(k_{\mathrm{obs}}\right)$ for the decay of $\left[(\mathrm{N} 4 \mathrm{Py}) \mathrm{Fe}^{\mathrm{IV}}(\mathrm{O})\right]^{2+}$ on the concentrations of $\mathrm{N}$-(4-chlorobenzyl)acetamide in $\mathrm{CH}_{3} \mathrm{CN}$ at $25{ }^{\circ} \mathrm{C}$ $\left(r^{2}=0.996\right)$. 


\begin{tabular}{cll}
\hline $\begin{array}{c}\text { [N-(4-methylbenzyl)acetamide }] \\
(\mathbf{M})\end{array}$ & $\boldsymbol{k}_{(\mathbf{o b s})}\left(\mathbf{s}^{-1}\right)$ & Std. Error \\
\hline 0.020 & $8.00 \times 10^{-4}$ & $2.64 \times 10^{-5}$ \\
0.030 & $1.20 \times 10^{-3}$ & $3.96 \times 10^{-5}$ \\
0.040 & $1.60 \times 10^{-3}$ & $5.28 \times 10^{-5}$ \\
0.050 & $2.00 \times 10^{-3}$ & $6.60 \times 10^{-5}$ \\
0.060 & $2.50 \times 10^{-3}$ & $8.25 \times 10^{-5}$
\end{tabular}

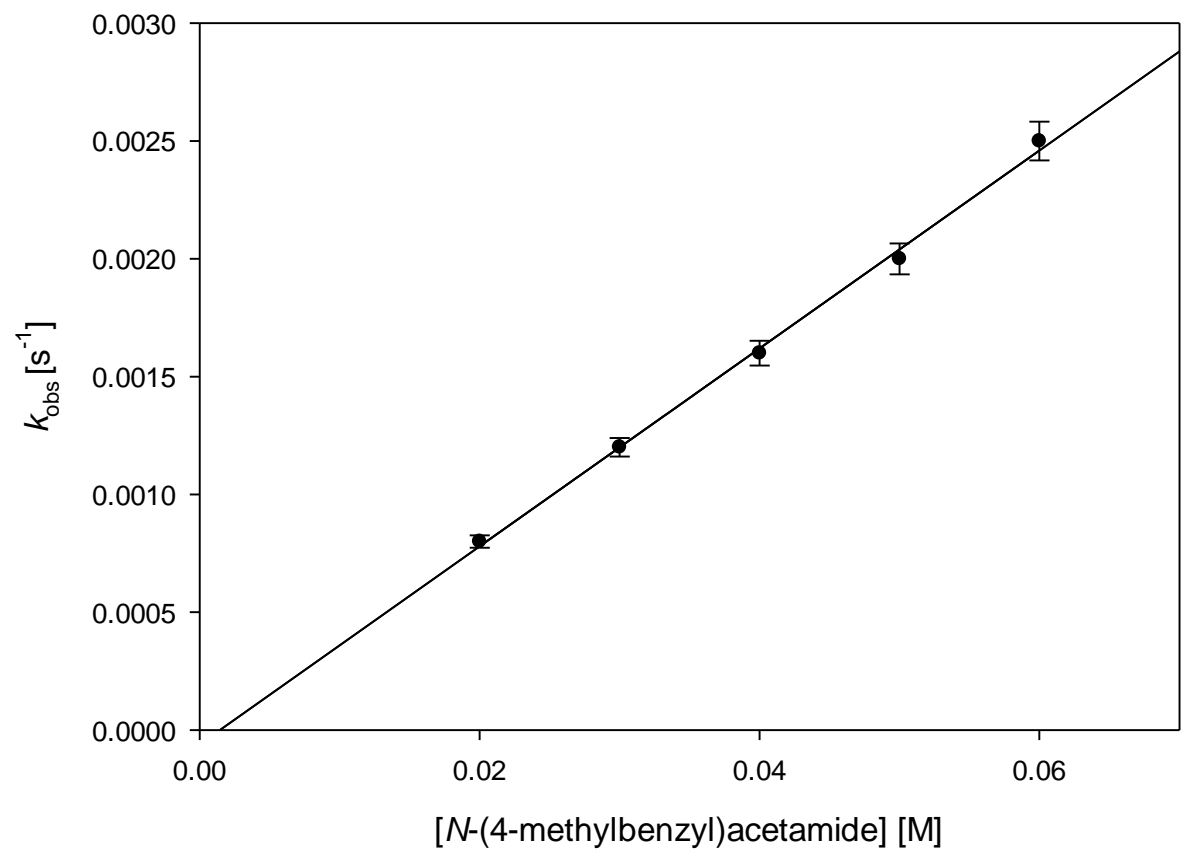

Figure S22. Dependence of pseudo-first order rate constants $\left(k_{\mathrm{obs}}\right)$ for the decay of $\left[(\mathrm{N} 4 \mathrm{Py}) \mathrm{Fe}^{\mathrm{IV}}(\mathrm{O})\right]^{2+}$ on the concentrations of $N$-(4-methylbenzyl)acetamide in $\mathrm{CH}_{3} \mathrm{CN}$ at $25{ }^{\circ} \mathrm{C}$ $\left(\mathrm{r}^{2}=0.998\right)$. 
Dependence of $\boldsymbol{k}_{(\mathrm{obs})}$ for the decay of PINO on the concentration of hydrocarbons, amides and ethers.

Hydrocarbons

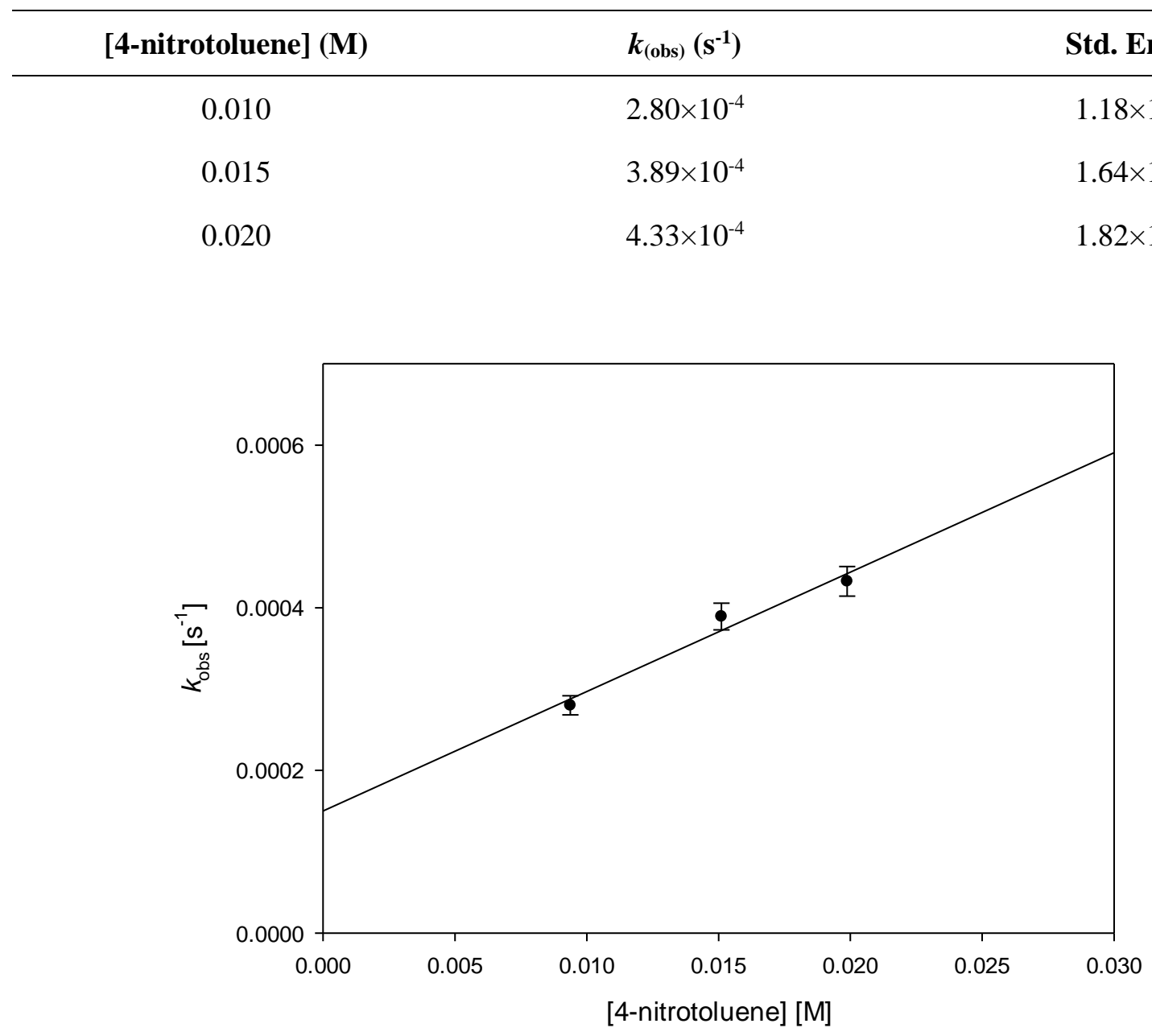

Figure S23. Dependence of pseudo-first order rate constants $\left(k_{\mathrm{obs}}\right)$ for the decay of PINO on the concentrations of 4-nitrotoluene in $\mathrm{CH}_{3} \mathrm{CN}$ at $25^{\circ} \mathrm{C}\left(\mathrm{r}^{2}=0.963\right)$. 


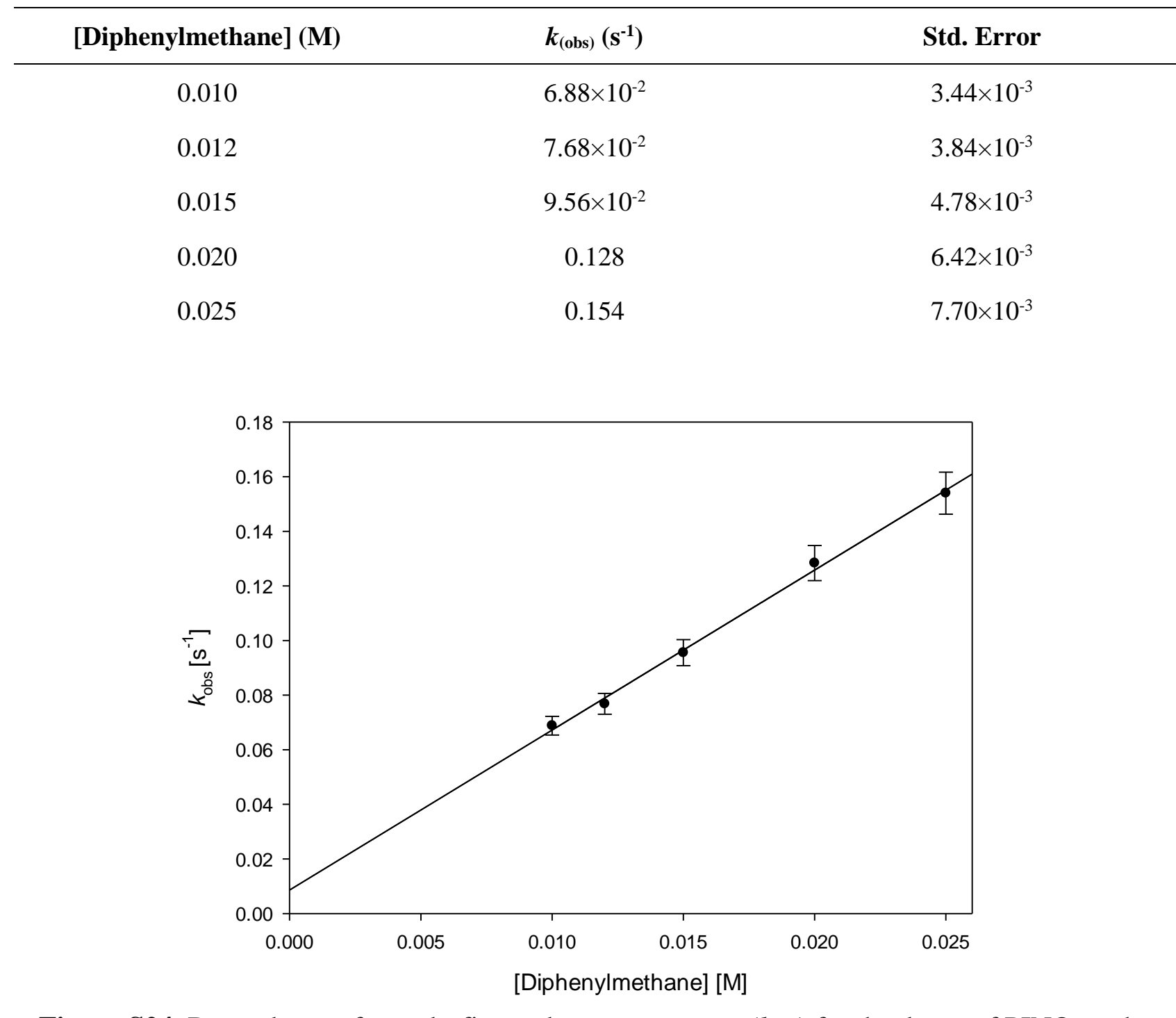

Figure S24. Dependence of pseudo-first order rate constants $\left(k_{\mathrm{obs}}\right)$ for the decay of PINO on the concentrations of Diphenylmethane in $\mathrm{CH}_{3} \mathrm{CN}$ at $25^{\circ} \mathrm{C}\left(\mathrm{r}^{2}=0.997\right)$. 


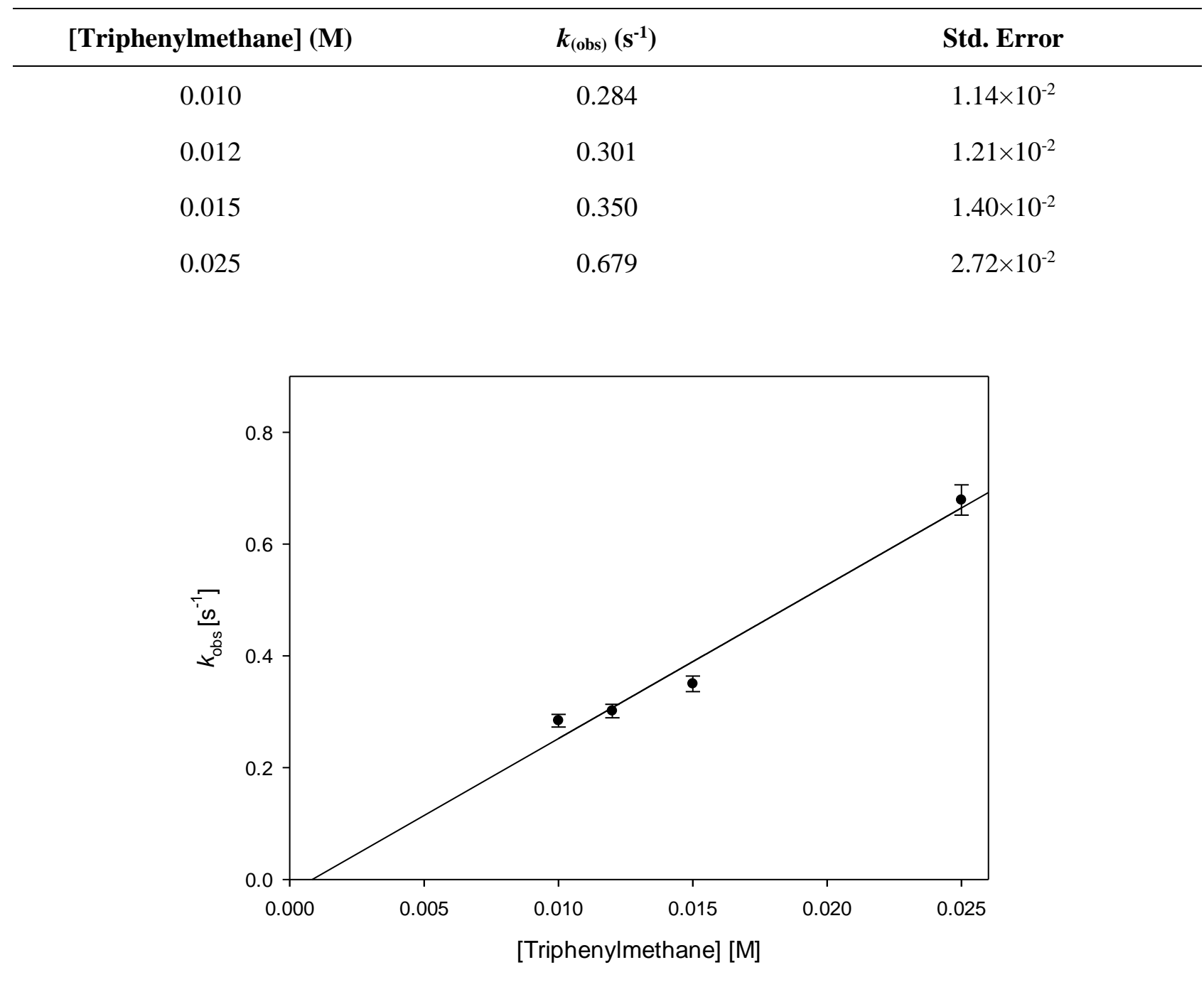

Figure S25. Dependence of pseudo-first order rate constants $\left(k_{\mathrm{obs}}\right)$ for the decay of PINO on the concentrations of Triphenylmethane in $\mathrm{CH}_{3} \mathrm{CN}$ at $25^{\circ} \mathrm{C}\left(\mathrm{r}^{2}=0.973\right)$. 


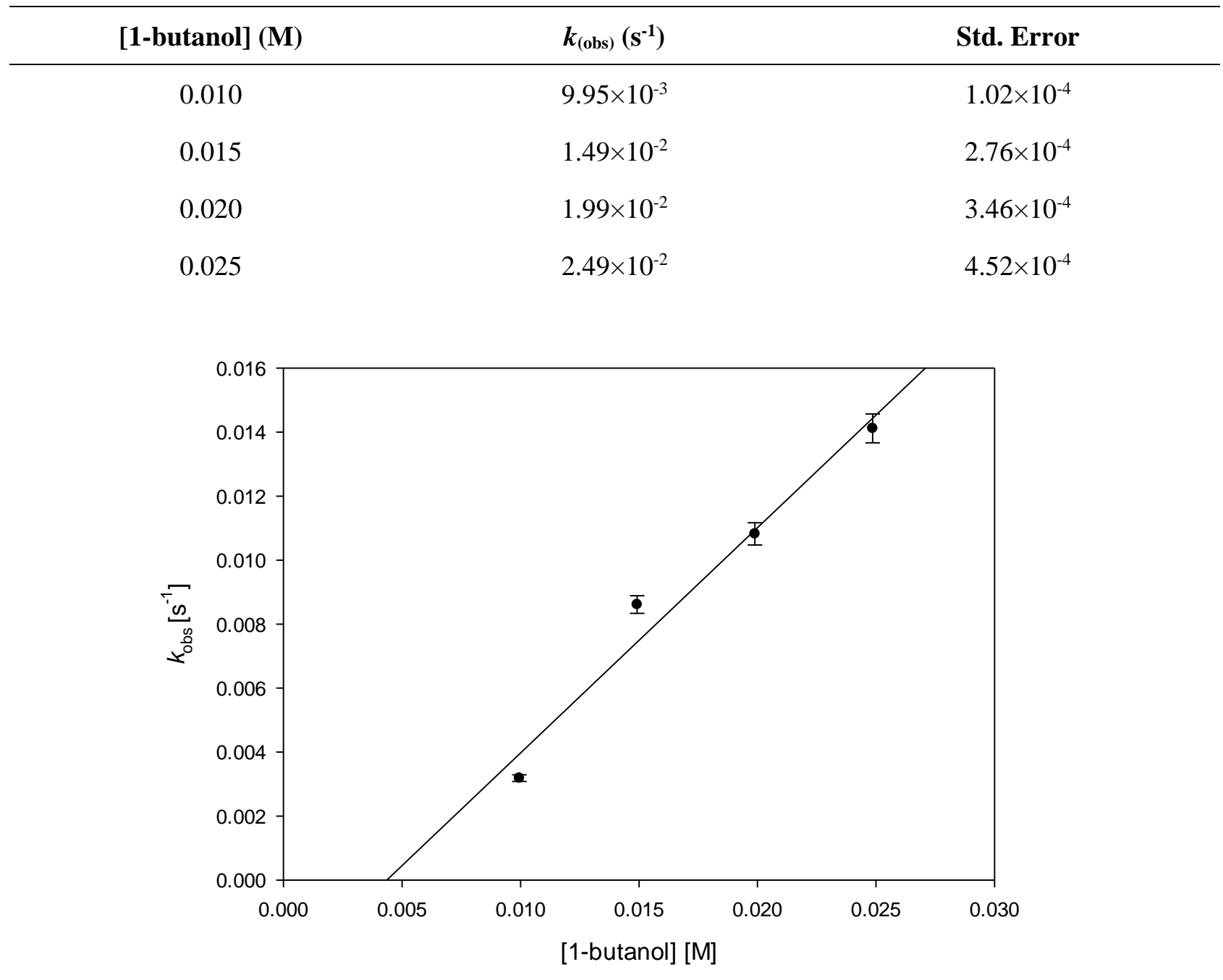

Figure S26. Dependence of pseudo-first order rate constants $\left(k_{\mathrm{obs}}\right)$ for the decay of PINO on the concentrations of 1-butanol in $\mathrm{CH}_{3} \mathrm{CN}$ at $25{ }^{\circ} \mathrm{C}\left(\mathrm{r}^{2}=0.967\right)$. 


\begin{tabular}{ccc}
\hline [1-decanol] $(\mathbf{M})$ & $\boldsymbol{k}_{(\mathbf{o b s})}\left(\mathbf{s}^{\mathbf{- 1}}\right)$ & Std. Error \\
\hline 0.015 & 0.012 & $6.08 \times 10^{-4}$ \\
0.020 & 0.016 & $7.29 \times 10^{-4}$ \\
0.025 & 0.021 & $9.54 \times 10^{-4}$ \\
0.030 & 0.026 & $1.15 \times 10^{-3}$
\end{tabular}

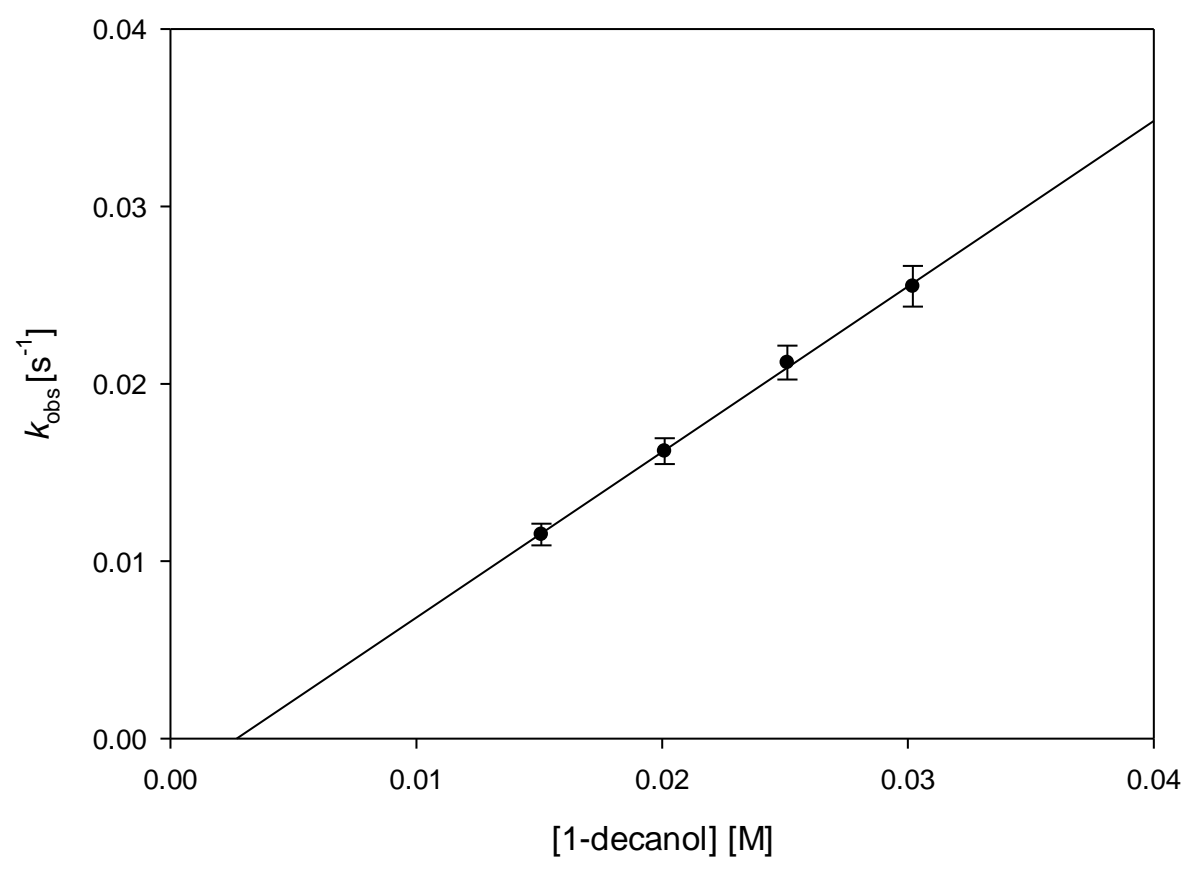

Figure S27. Dependence of pseudo-first order rate constants $\left(k_{\mathrm{obs}}\right)$ for the decay of PINO on the concentrations of 1 -decanol in $\mathrm{CH}_{3} \mathrm{CN}$ at $25{ }^{\circ} \mathrm{C}\left(\mathrm{r}^{2}=0.999\right)$. 


\begin{tabular}{cll}
\hline [3-pentanol] $(\mathbf{M})$ & $\boldsymbol{k}_{\text {(obs) }}\left(\mathbf{s}^{-1}\right)$ & Std. Error \\
\hline 0.011 & $1.79 \times 10^{-2}$ & $3.58 \times 10^{-4}$ \\
0.012 & $2.16 \times 10^{-2}$ & $4.31 \times 10^{-4}$ \\
0.015 & $2.64 \times 10^{-2}$ & $5.28 \times 10^{-4}$ \\
0.020 & $3.39 \times 10^{-2}$ & $6.77 \times 10^{-4}$ \\
0.025 & $4.34 \times 10^{-2}$ & $8.67 \times 10^{-4}$
\end{tabular}

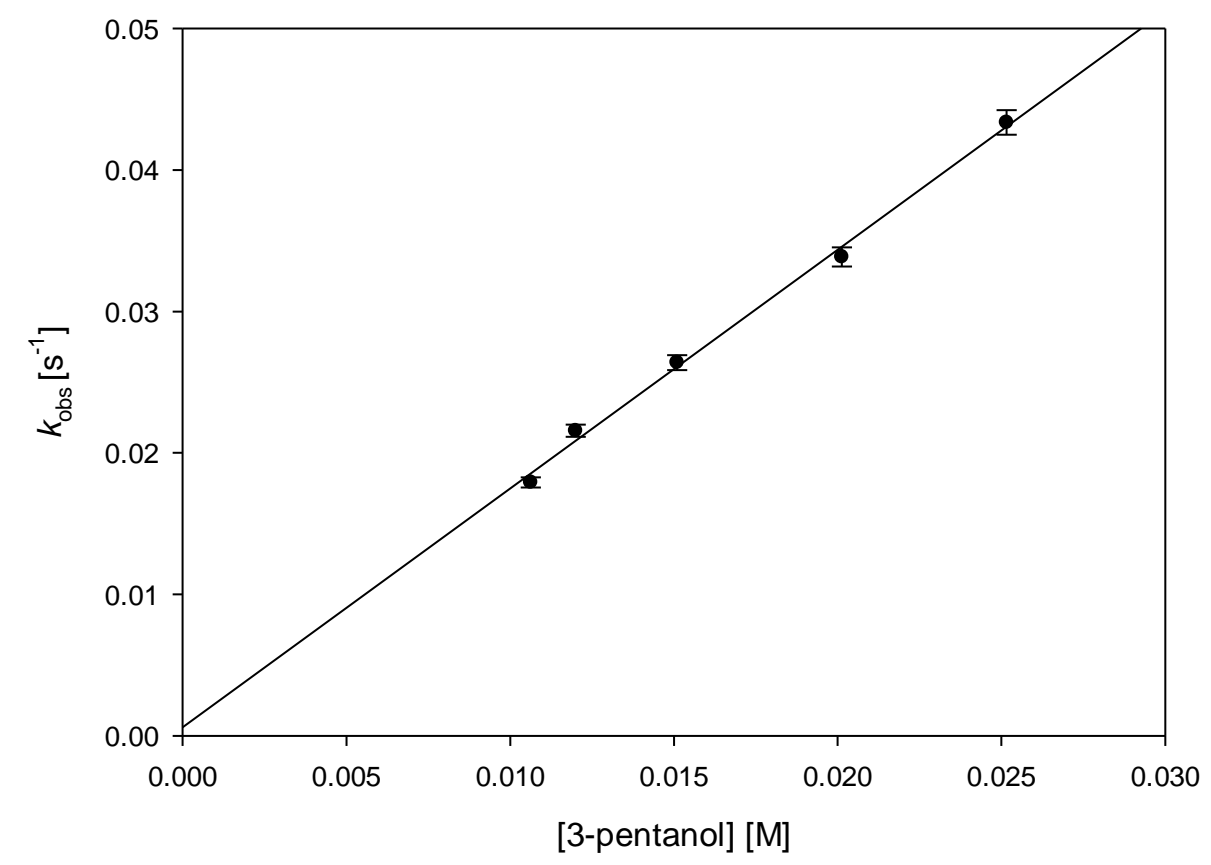

Figure S28. Dependence of pseudo-first order rate constants $\left(k_{\mathrm{obs}}\right)$ for the decay of PINO on the concentrations of 3-pentanol in $\mathrm{CH}_{3} \mathrm{CN}$ at $25{ }^{\circ} \mathrm{C}\left(\mathrm{r}^{2}=0.996\right)$. 


\begin{tabular}{ccc}
\hline [Cyclopentanol] $(\mathbf{M})$ & $\boldsymbol{k}_{\text {(obs) }}\left(\mathbf{s}^{-1}\right)$ & Std. Error \\
\hline $9.90 \times 10^{-3}$ & 0.024 & $3.34 \times 10^{-4}$ \\
0.015 & 0.033 & $4.64 \times 10^{-4}$ \\
0.020 & 0.041 & $5.79 \times 10^{-4}$ \\
0.025 & 0.050 & $6.97 \times 10^{-4}$ \\
0.030 & 0.059 & $8.29 \times 10^{-4}$
\end{tabular}

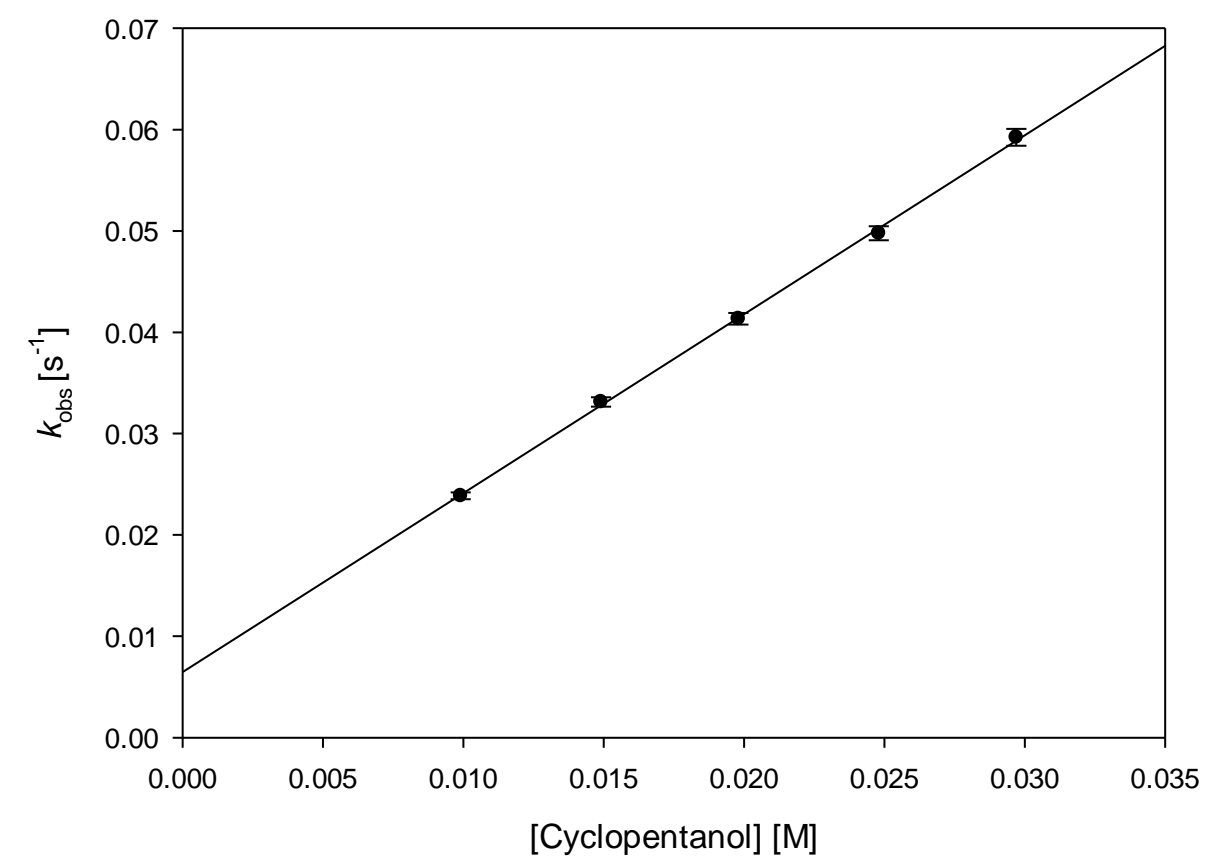

Figure S29. Dependence of pseudo-first order rate constants $\left(k_{\mathrm{obs}}\right)$ for the decay of PINO on the concentrations of Cyclopentanol in $\mathrm{CH}_{3} \mathrm{CN}$ at $25^{\circ} \mathrm{C}\left(\mathrm{r}^{2}=0.999\right)$. 


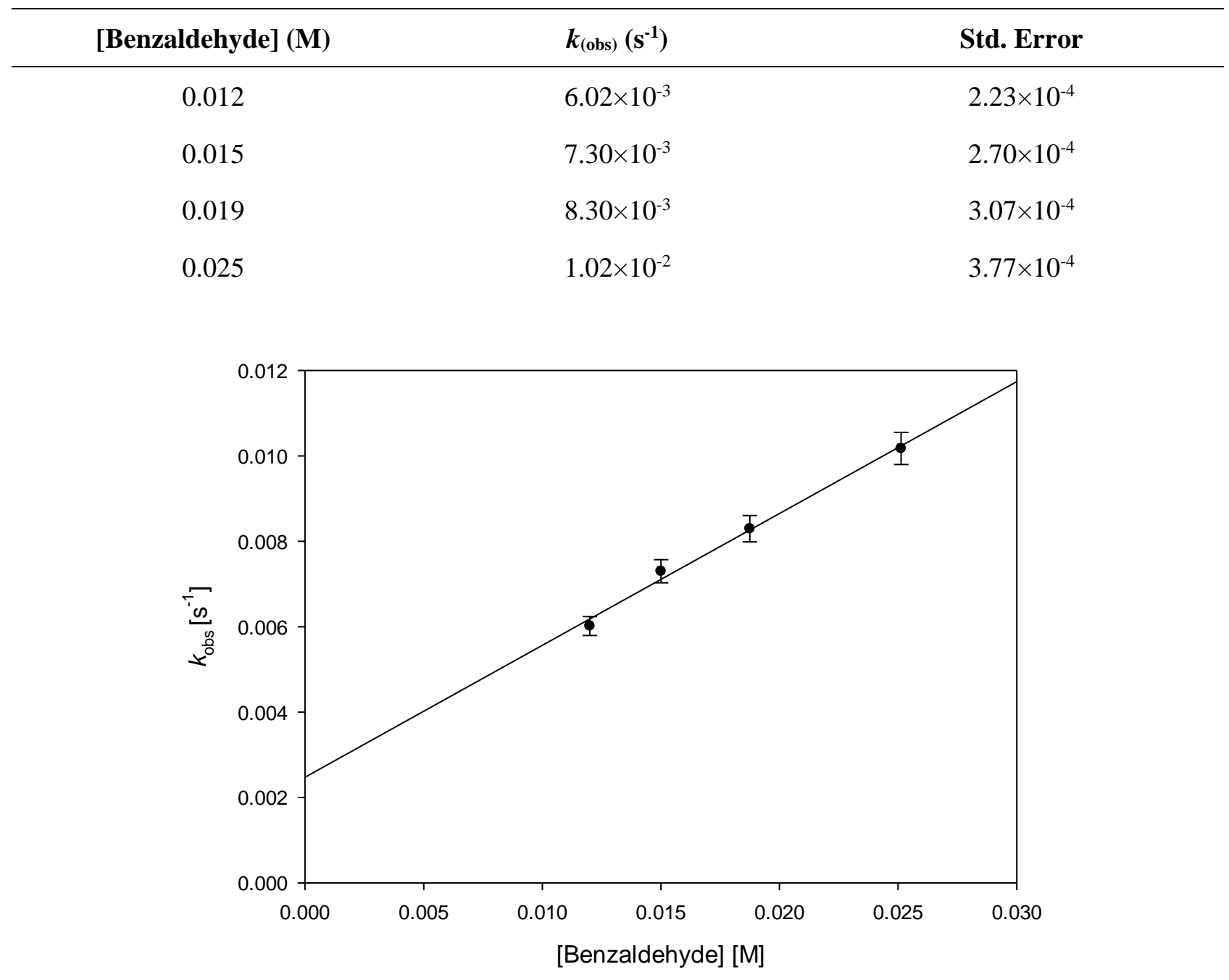

Figura S30. Dependence of pseudo-first order rate constants $\left(k_{\mathrm{obs}}\right)$ for the decay of PINO on the concentrations of Benzaldehyde in $\mathrm{CH}_{3} \mathrm{CN}$ at $25^{\circ} \mathrm{C}\left(\mathrm{r}^{2}=0.993\right)$. 
Ethers

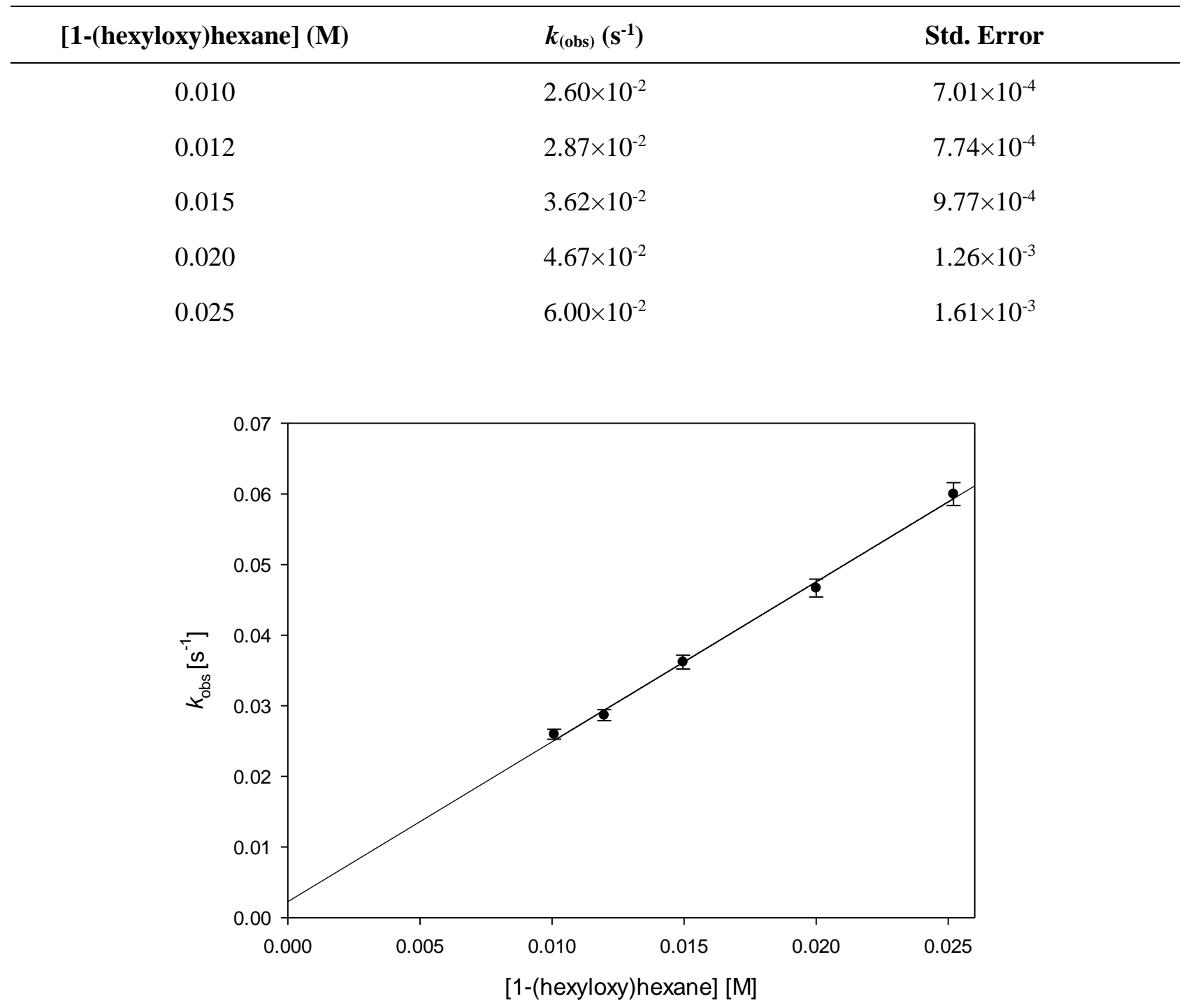

Figure S31. Dependence of pseudo-first order rate constants $\left(k_{\mathrm{obs}}\right)$ for the decay of PINO on the concentrations of 1-(hexyloxy)hexane in $\mathrm{CH}_{3} \mathrm{CN}$ at $25^{\circ} \mathrm{C}\left(\mathrm{r}^{2}=0.997\right)$. 


\begin{tabular}{ccc}
\hline $\begin{array}{c}\text { [1-methoxy-4-(methoxymethyl)benzene] } \\
(\mathbf{M})\end{array}$ & $\boldsymbol{k}_{\text {(obs) }}\left(\mathbf{s}^{-\mathbf{1}}\right)$ & Std. Error \\
\hline 0.010 & 0.330 & $1.06 \times 10^{-2}$ \\
0.012 & 0.354 & $1.13 \times 10^{-2}$ \\
0.015 & 0.469 & $1.50 \times 10^{-2}$ \\
0.020 & 0.544 & $1.74 \times 10^{-2}$
\end{tabular}

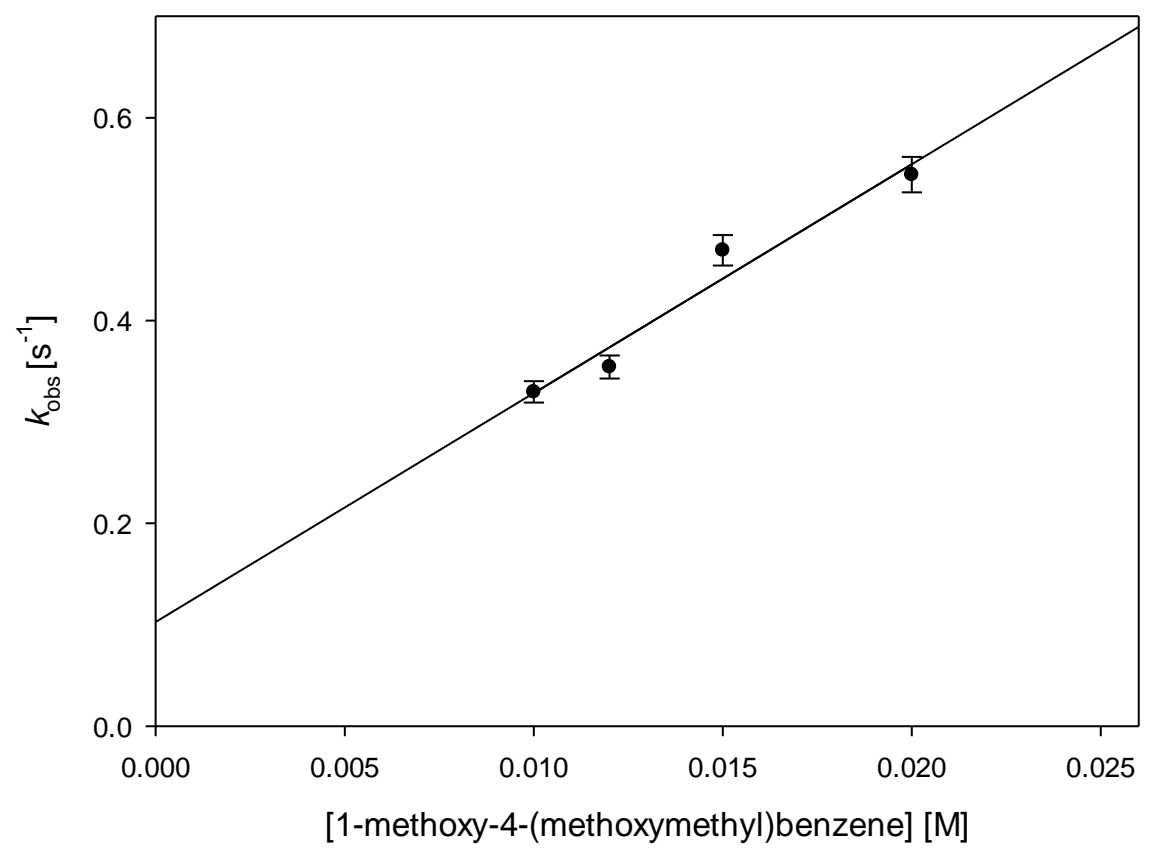

Figure S32. Dependence of pseudo-first order rate constants $\left(k_{\mathrm{obs}}\right)$ for the decay of PINO on the concentrations of 1-methoxy-4-(methoxymethyl)benzene in $\mathrm{CH}_{3} \mathrm{CN}$ at $25^{\circ} \mathrm{C}\left(\mathrm{r}^{2}=0.958\right)$. 
Amides

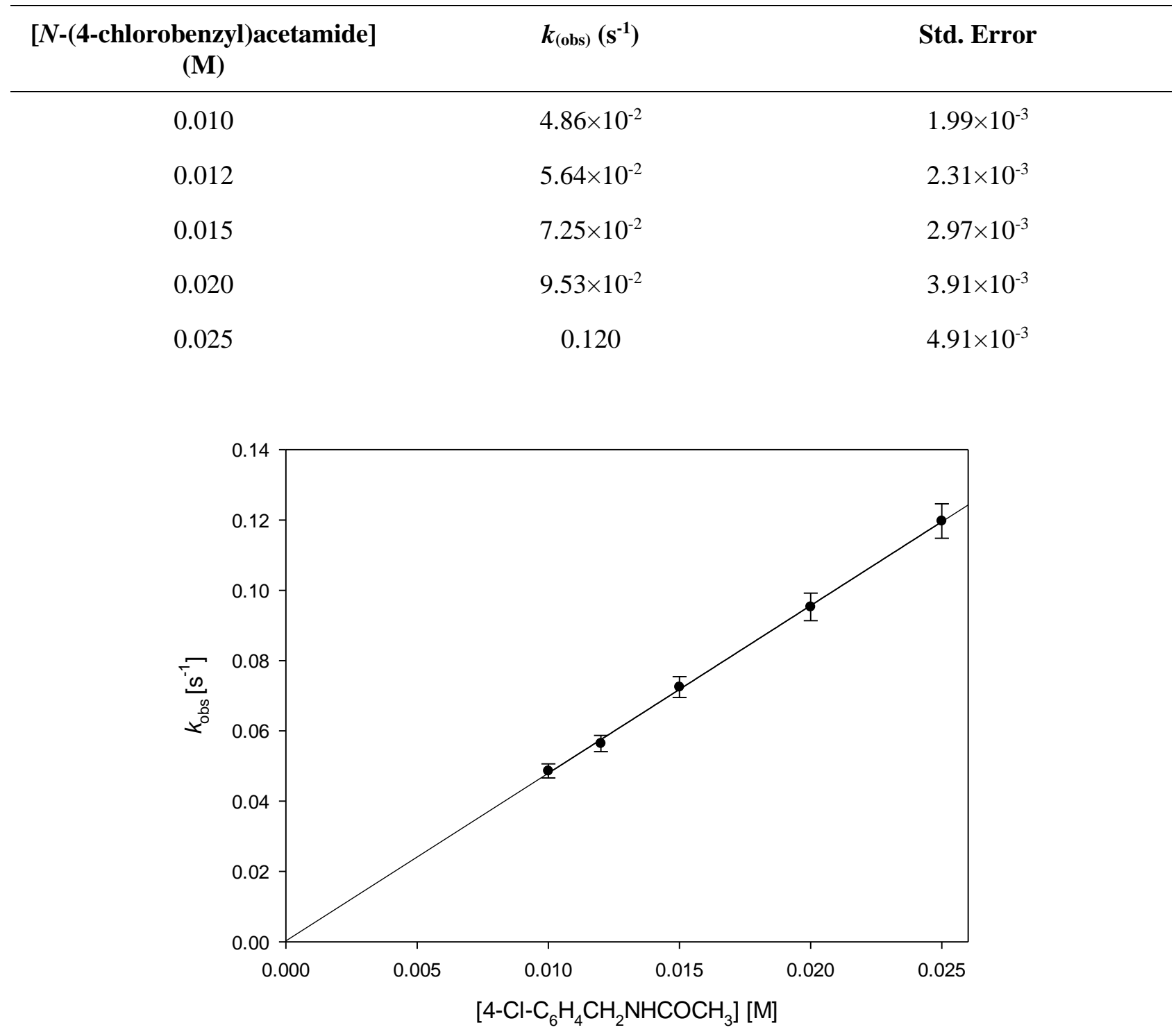

Figure S33. Dependence of pseudo-first order rate constants $\left(k_{\mathrm{obs}}\right)$ for the decay of PINO on the concentrations of $\mathrm{N}$-(4-chlorobenzyl)acetamide in $\mathrm{CH}_{3} \mathrm{CN}$ at $25^{\circ} \mathrm{C}\left(\mathrm{r}^{2}=0.999\right)$. 
Decay of absorbance recorded at $695 \mathrm{~nm}$ in the oxidation of hydrocarbons, alcohols, aldehydes, ethers and amides with $\left[(\mathrm{N} 4 \mathrm{Py}) \mathrm{Fe}^{\mathrm{IV}}(\mathrm{O})\right]^{2+}$ in the absence and in the presence of NHPI.
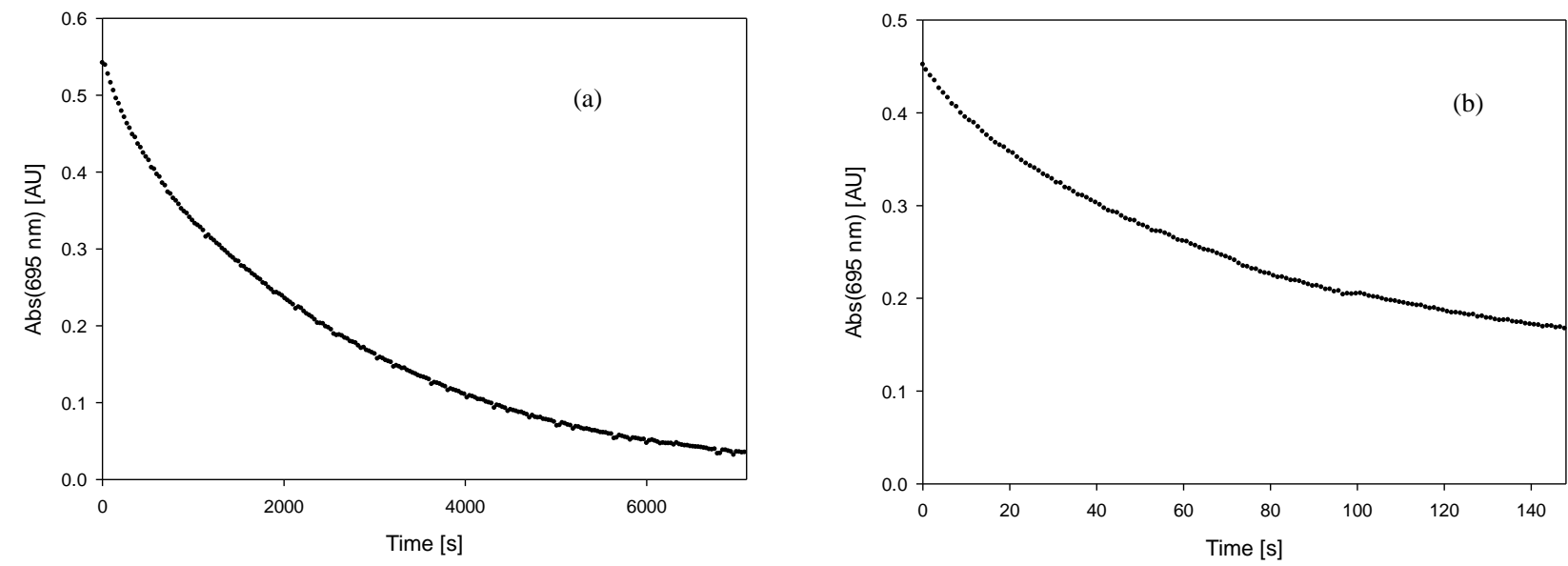

Figure S34. Decay of absorbance recorded at $695 \mathrm{~nm}$ in the oxidation of Toluene $(1 \mathrm{M})$ with $\left[(\mathrm{N} 4 \mathrm{Py}) \mathrm{Fe}^{\mathrm{IV}}=\mathrm{O}\right]^{2+}(1.5 \mathrm{mM})(\mathrm{a})$ in the absence and $(\mathrm{b})$ in the presence of $20 \mathrm{~mol} \%$ of NHPI in $\mathrm{CH}_{3} \mathrm{CN}$.
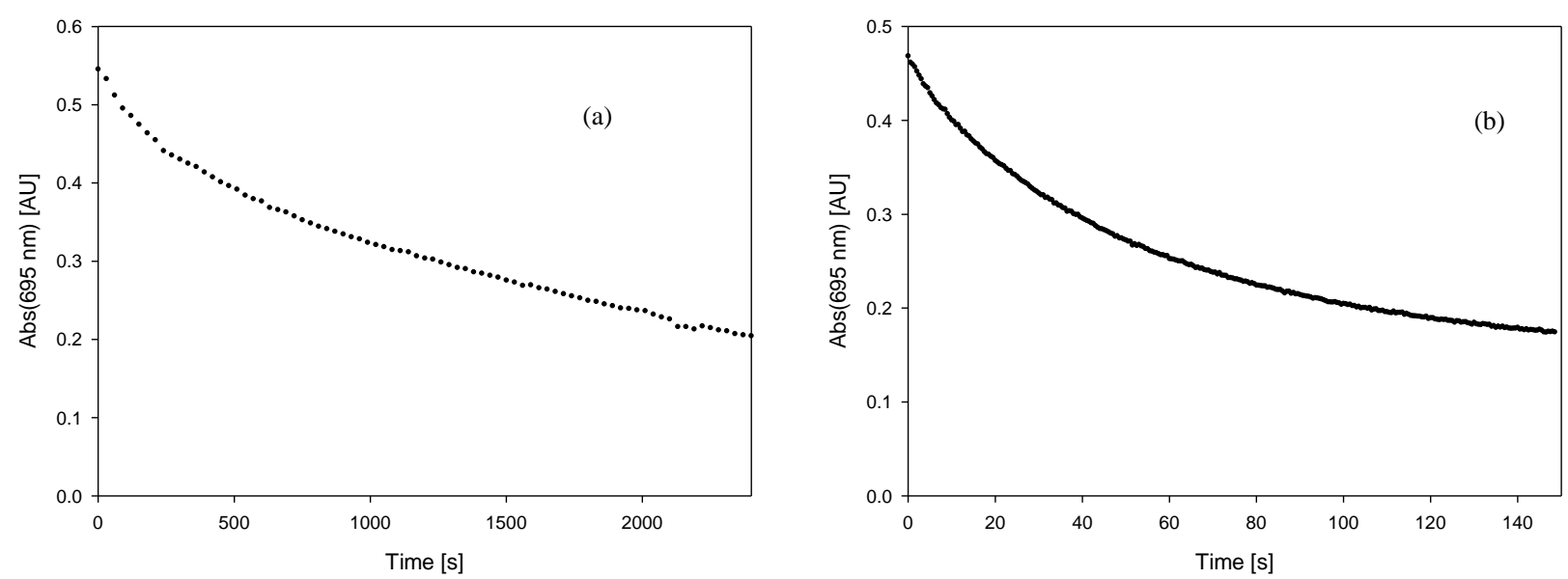

Figure S35. Decay of absorbance recorded at $695 \mathrm{~nm}$ in the oxidation of $p$-Xilene $(200 \mathrm{mM})$ with $\left[(\mathrm{N} 4 \mathrm{Py}) \mathrm{Fe}^{\mathrm{IV}}=\mathrm{O}\right]^{2+}(1.5 \mathrm{mM})(\mathrm{a})$ in the absence and (b) in the presence of $20 \mathrm{~mol} \%$ of NHPI in $\mathrm{CH}_{3} \mathrm{CN}$. 

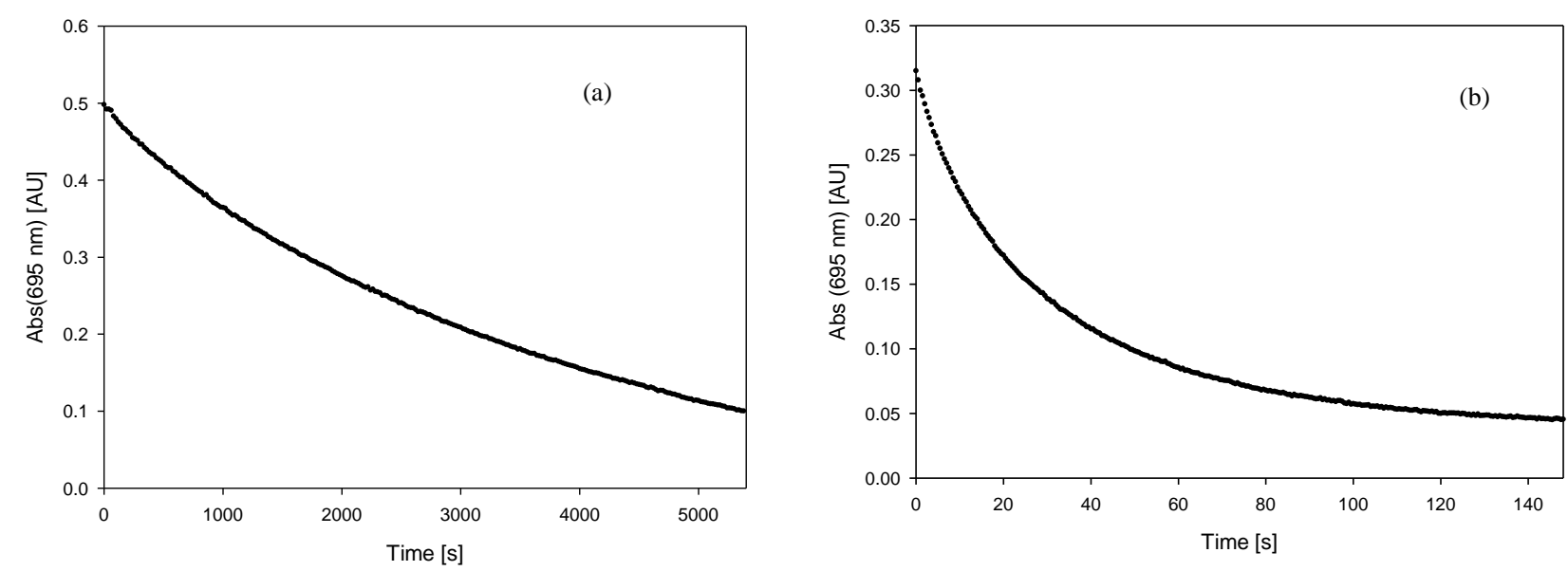

Figure S36. Decay of absorbance recorded at $695 \mathrm{~nm}$ in the oxidation of 1-methoxy-4-methylbenzene $(150 \mathrm{mM})$ with $\left[(\mathrm{N} 4 \mathrm{Py}) \mathrm{Fe}^{\mathrm{IV}}=\mathrm{O}\right]^{2+}(1.5 \mathrm{mM})(\mathrm{a})$ in the absence and $(\mathrm{b})$ in the presence of $20 \mathrm{~mol} \%$ of NHPI in $\mathrm{CH}_{3} \mathrm{CN}$.
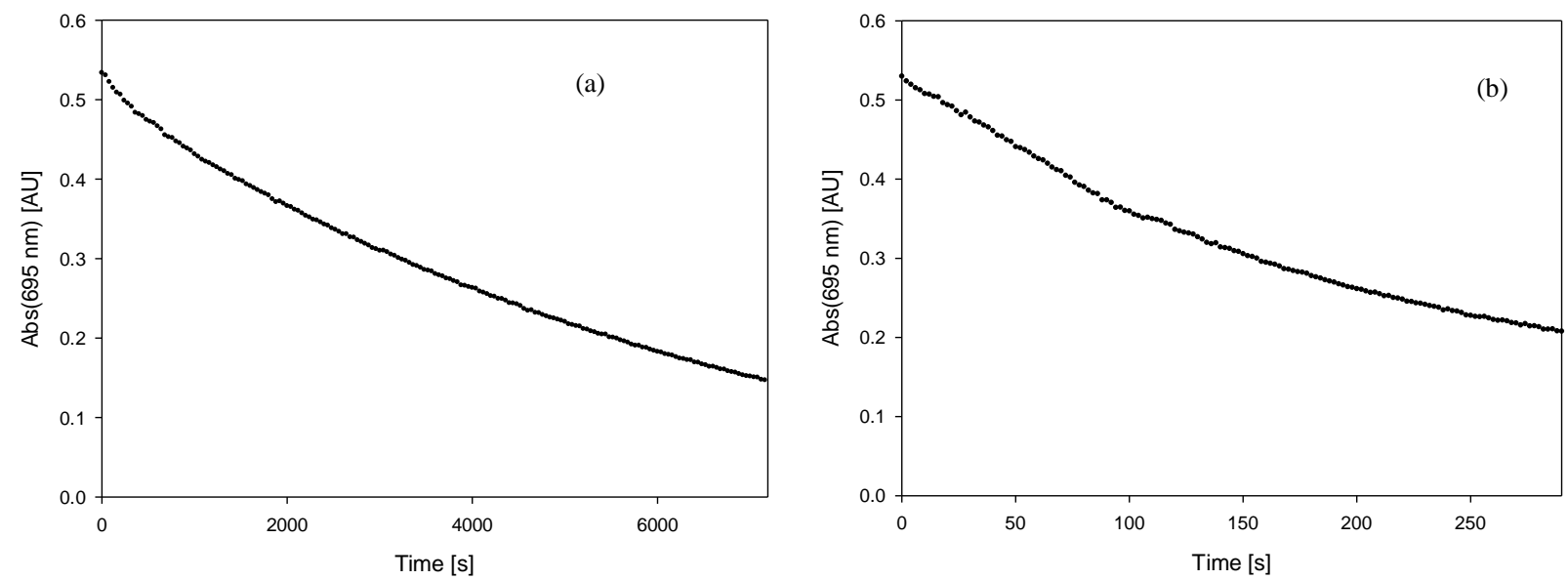

Figure S37. Decay of absorbance recorded at $695 \mathrm{~nm}$ in the oxidation of 1-(p-tolyl)ethanone (400 $\mathrm{mM})$ with $\left[(\mathrm{N} 4 \mathrm{Py}) \mathrm{Fe}^{\mathrm{IV}}=\mathrm{O}\right]^{2+}(1.5 \mathrm{mM})(\mathrm{a})$ in the absence and (b) in the presence of $20 \mathrm{~mol} \%$ of NHPI in $\mathrm{CH}_{3} \mathrm{CN}$. 

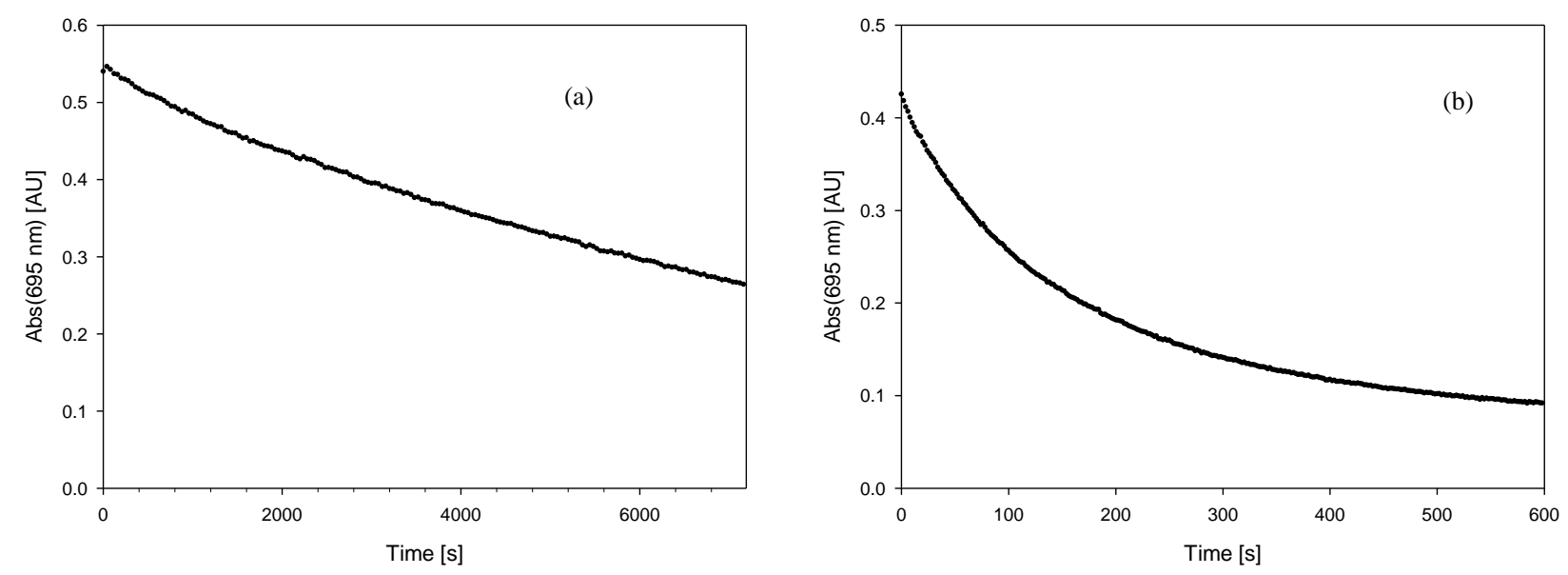

Figure S38. Decay of absorbance recorded at $695 \mathrm{~nm}$ in the oxidation of 4-(trifluoromethyl)toluene $(600 \mathrm{mM})$ with $\left[(\mathrm{N} 4 \mathrm{Py}) \mathrm{Fe}^{\mathrm{IV}}=\mathrm{O}\right]^{2+}(1.5 \mathrm{mM})(\mathrm{a})$ in the absence and $(\mathrm{b})$ in the presence of $20 \mathrm{~mol} \%$ of NHPI in $\mathrm{CH}_{3} \mathrm{CN}$.
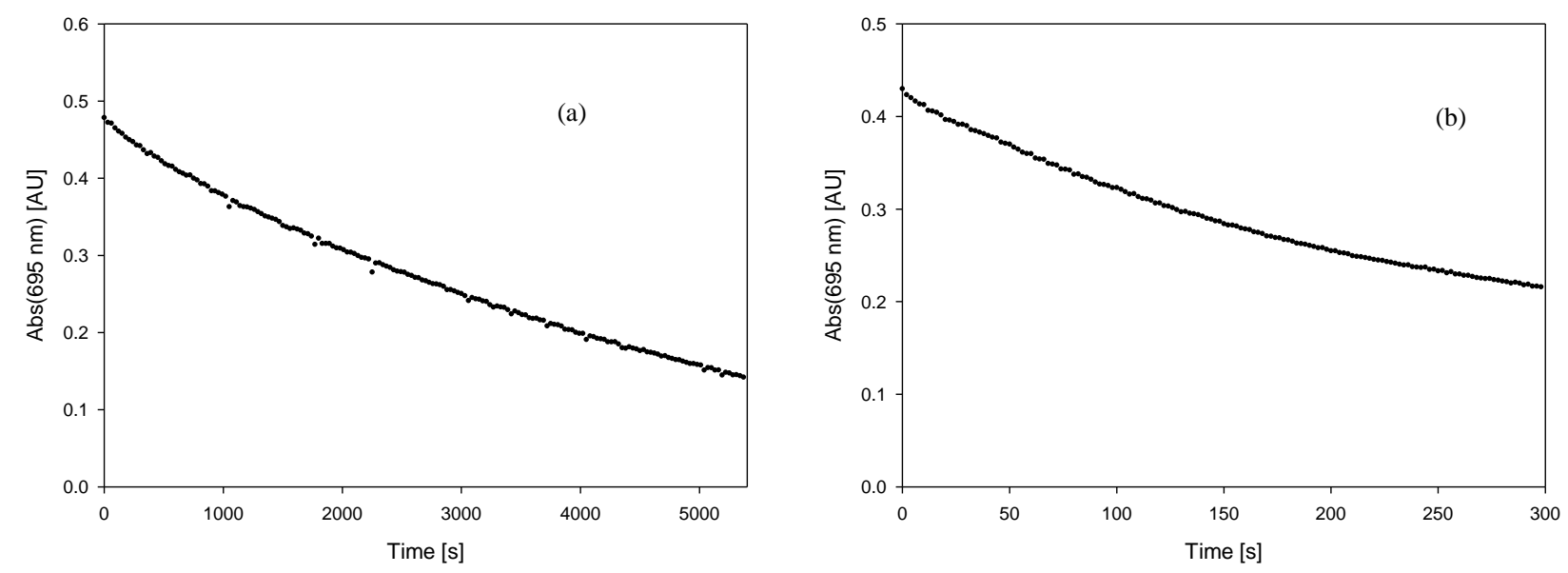

Figure S39. Decay of absorbance recorded at $695 \mathrm{~nm}$ in the oxidation of 4-nitrotoluene (1 M) with $\left[(\mathrm{N} 4 \mathrm{Py}) \mathrm{Fe}^{\mathrm{IV}}=\mathrm{O}\right]^{2+}(1.5 \mathrm{mM})(\mathrm{a})$ in the absence and $(\mathrm{b})$ in the presence of $20 \mathrm{~mol} \%$ of NHPI in $\mathrm{CH}_{3} \mathrm{CN}$. 

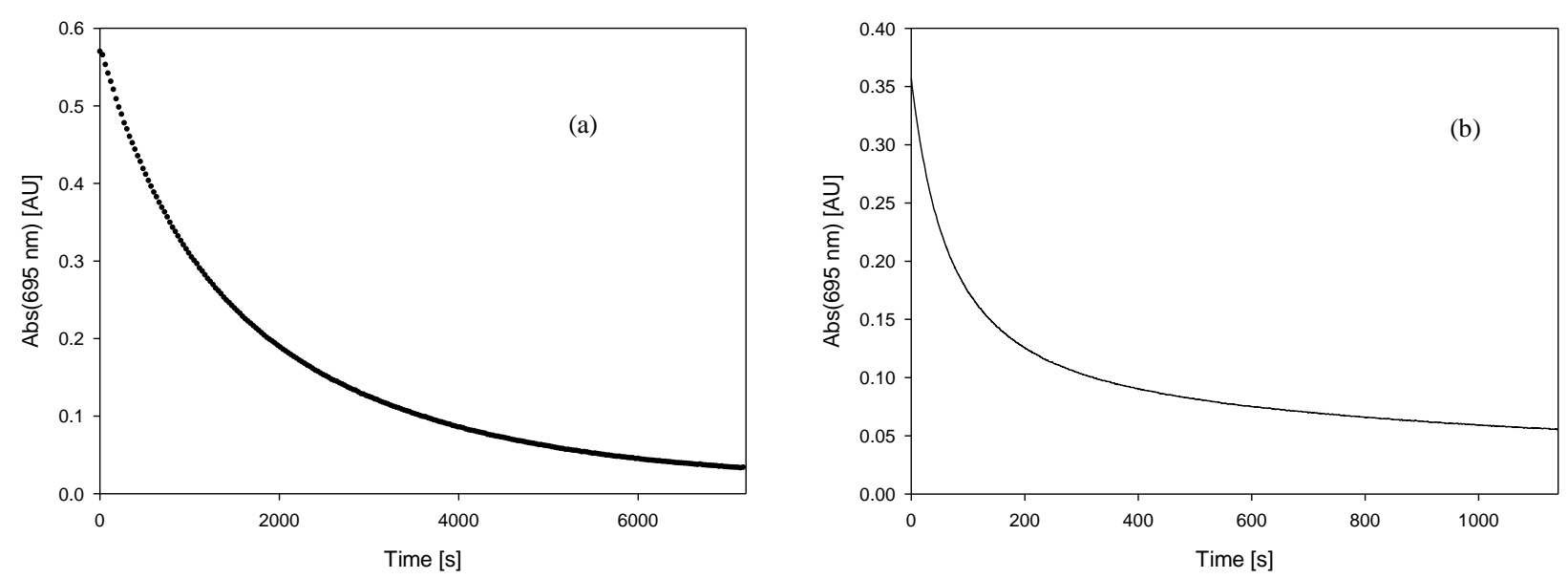

Figure S40. Decay of absorbance recorded at $695 \mathrm{~nm}$ in the oxidation of diphenylmethane (30 $\mathrm{mM})$ with $\left[(\mathrm{N} 4 \mathrm{Py}) \mathrm{Fe}^{\mathrm{IV}}=\mathrm{O}\right]^{2+}(1.5 \mathrm{mM})(\mathrm{a})$ in the absence and (b) in the presence of $20 \mathrm{~mol} \%$ of NHPI in $\mathrm{CH}_{3} \mathrm{CN}$.
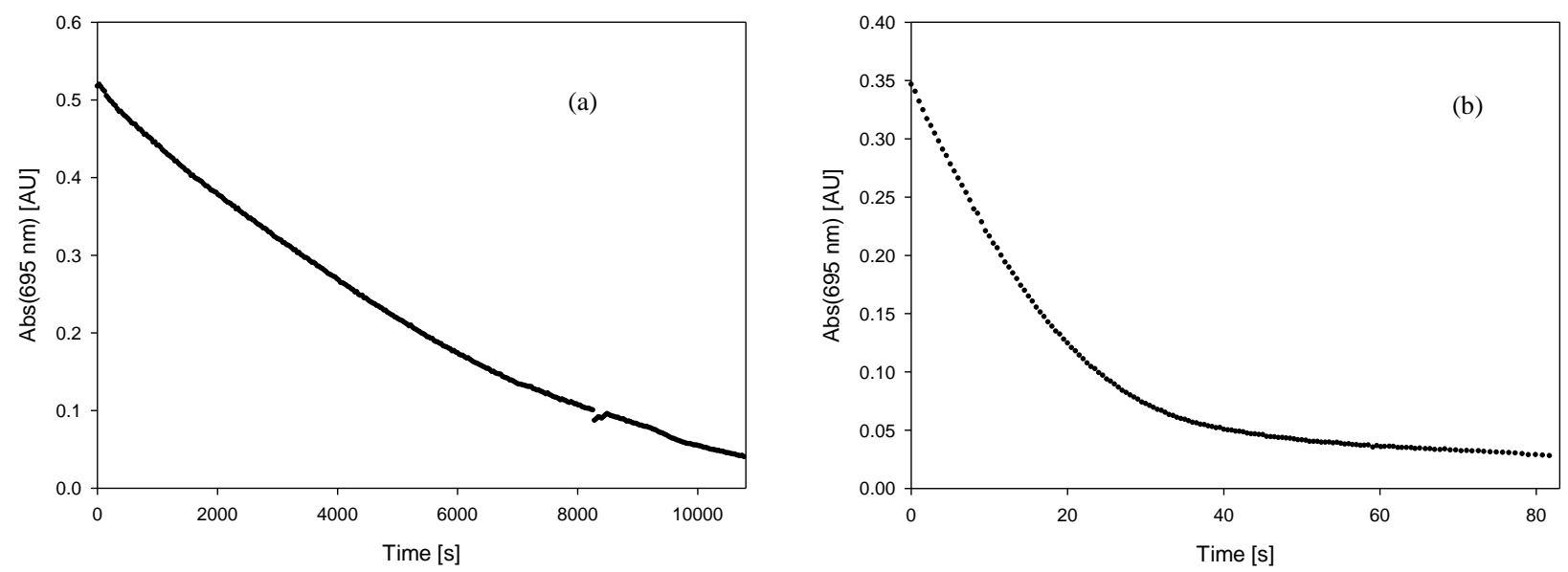

Figure S41. Decay of absorbance recorded at $695 \mathrm{~nm}$ in the oxidation of 1-butanol $(250 \mathrm{mM})$ with $\left[(\mathrm{N} 4 \mathrm{Py}) \mathrm{Fe}^{\mathrm{IV}}=\mathrm{O}\right]^{2+}(1.5 \mathrm{mM})(\mathrm{a})$ in the absence and (b) in the presence of $20 \mathrm{~mol} \%$ of NHPI in $\mathrm{CH}_{3} \mathrm{CN}$. 

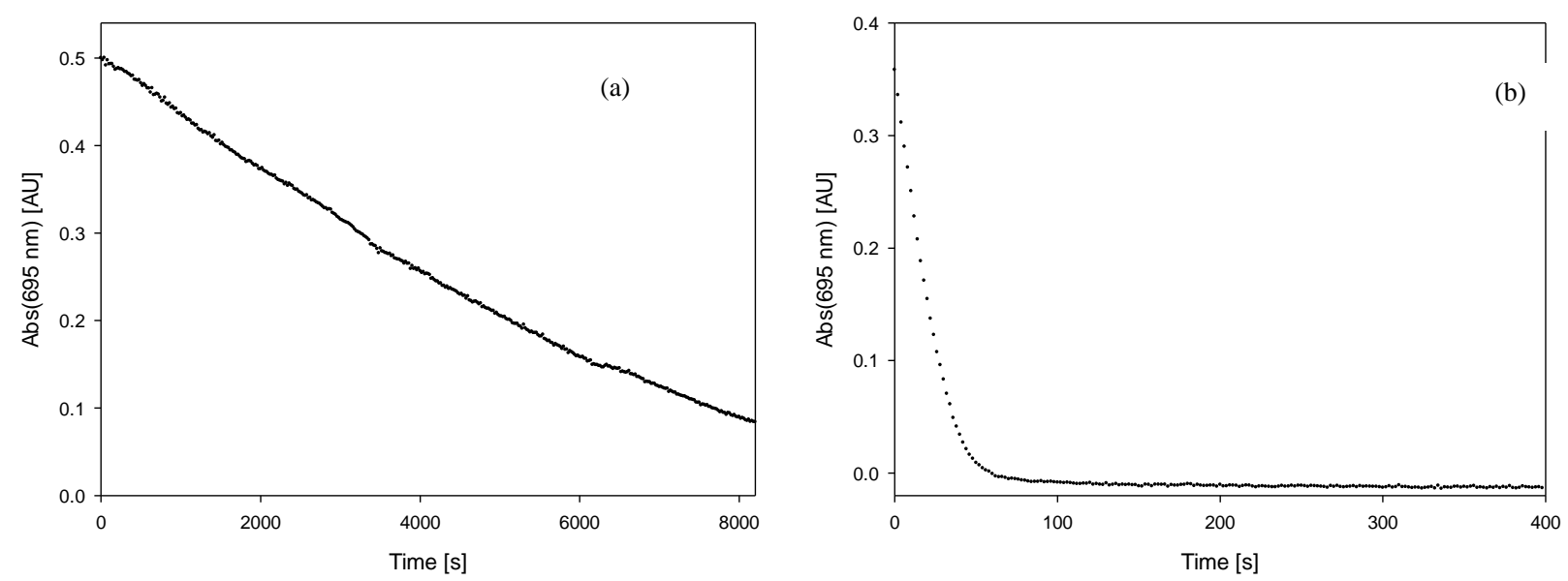

Figure S42. Decay of absorbance recorded at $695 \mathrm{~nm}$ in the oxidation of 1-decanol $(200 \mathrm{mM})$ with $\left[(\mathrm{N} 4 \mathrm{Py}) \mathrm{Fe}^{\mathrm{IV}}=\mathrm{O}\right]^{2+}(1.5 \mathrm{mM})(\mathrm{a})$ in the absence and (b) in the presence of $20 \mathrm{~mol} \%$ of NHPI in $\mathrm{CH}_{3} \mathrm{CN}$.
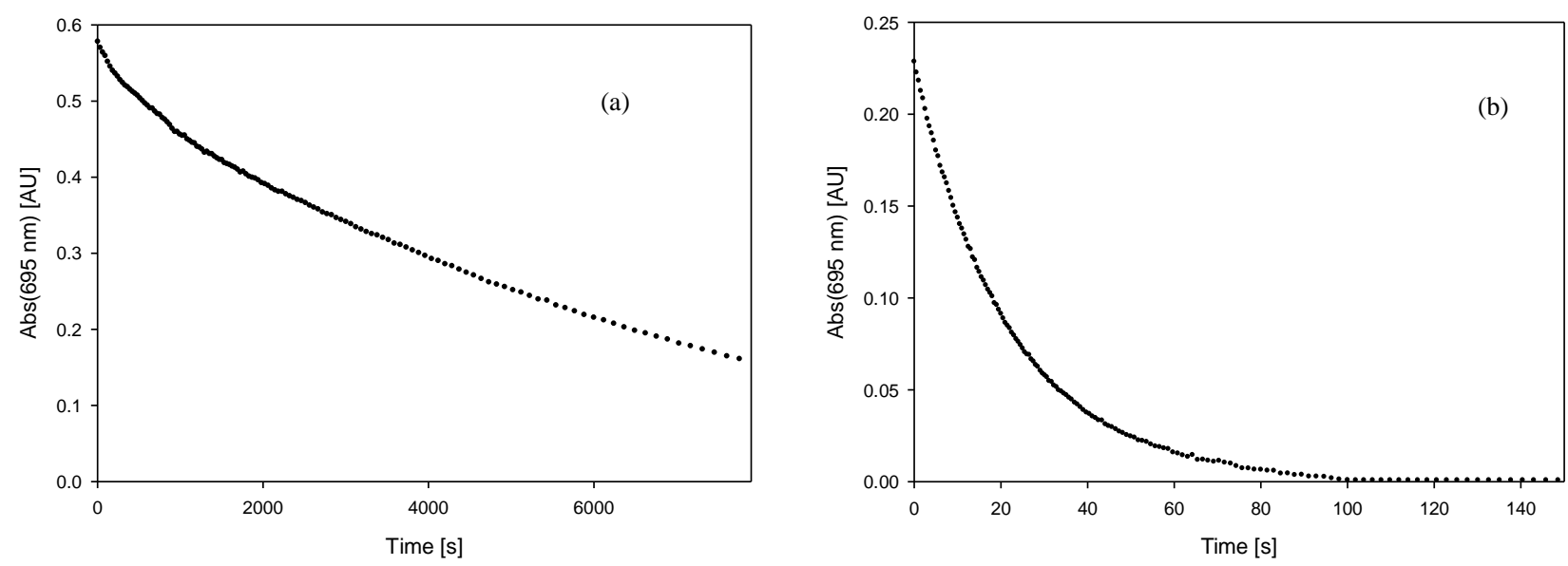

Figure S43. Decay of absorbance recorded at $695 \mathrm{~nm}$ in the oxidation of 3-pentanol $(250 \mathrm{mM})$ with $\left[(\mathrm{N} 4 \mathrm{Py}) \mathrm{Fe}^{\mathrm{IV}}=\mathrm{O}\right]^{2+}(1.5 \mathrm{mM})(\mathrm{a})$ in the absence and (b) in the presence of $20 \mathrm{~mol} \%$ of NHPI in $\mathrm{CH}_{3} \mathrm{CN}$. 

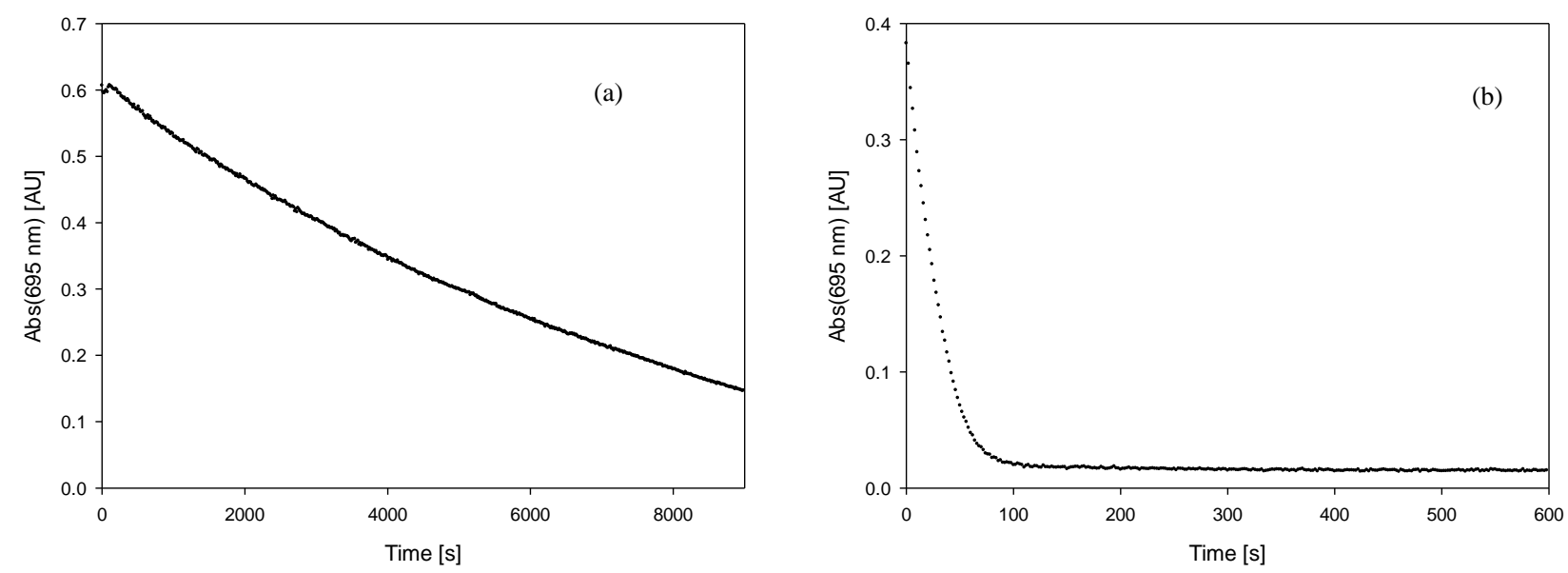

Figure S44. Decay of absorbance recorded at $695 \mathrm{~nm}$ in the oxidation of cyclopentanol (200 $\mathrm{mM})$ with $\left[(\mathrm{N} 4 \mathrm{Py}) \mathrm{Fe}^{\mathrm{IV}}=\mathrm{O}\right]^{2+}(1.5 \mathrm{mM})(\mathrm{a})$ in the absence and (b) in the presence of $20 \mathrm{~mol} \%$ of NHPI in $\mathrm{CH}_{3} \mathrm{CN}$.
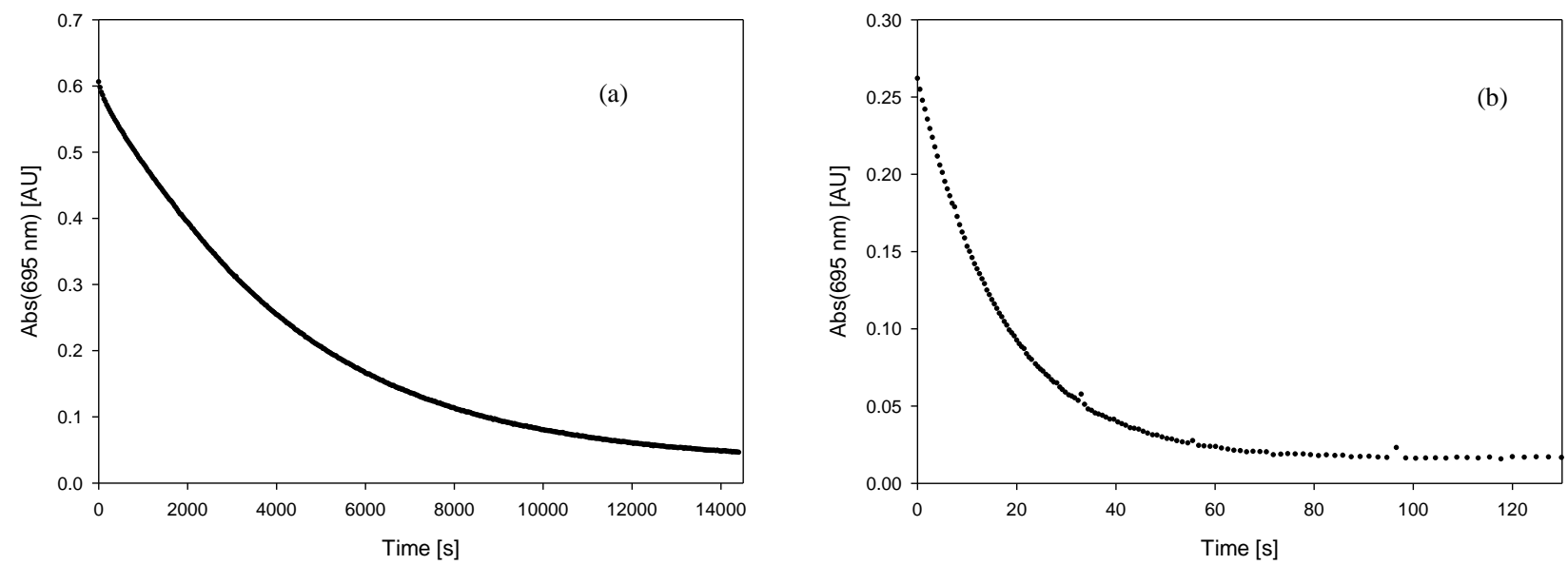

Figure S45. Decay of absorbance recorded at $695 \mathrm{~nm}$ in the oxidation of cyclohexanol (200 $\mathrm{mM})$ with $\left[(\mathrm{N} 4 \mathrm{Py}) \mathrm{Fe}^{\mathrm{IV}}=\mathrm{O}^{2+}(1.5 \mathrm{mM})(\mathrm{a})\right.$ in the absence and (b) in the presence of $20 \mathrm{~mol} \%$ of NHPI in $\mathrm{CH}_{3} \mathrm{CN}$. 

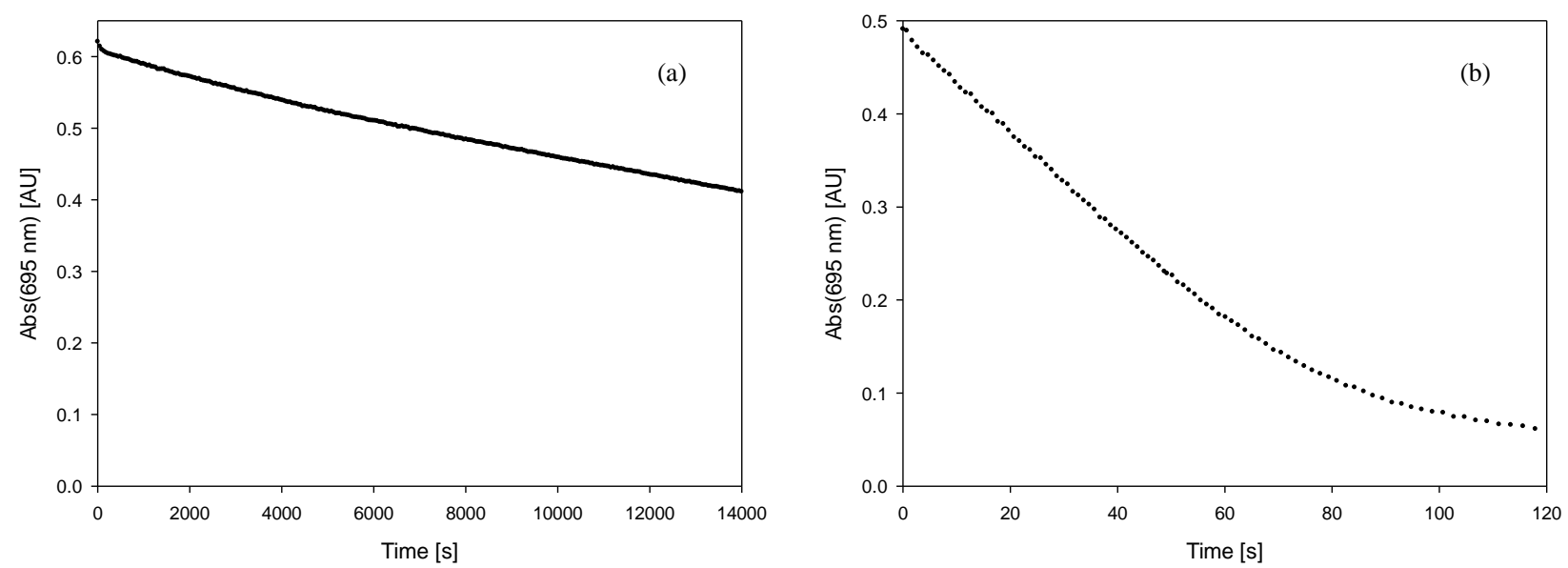

Figure S46. Decay of absorbance recorded at $695 \mathrm{~nm}$ in the oxidation of cyclohexanol- $d(200 \mathrm{mM})$ with $\left[(\mathrm{N} 4 \mathrm{Py}) \mathrm{Fe}^{\mathrm{IV}}=\mathrm{O}\right]^{2+}(1.5 \mathrm{mM})(\mathrm{a})$ in the absence and (b) in the presence of $20 \mathrm{~mol} \%$ of NHPI in $\mathrm{CH}_{3} \mathrm{CN}$.
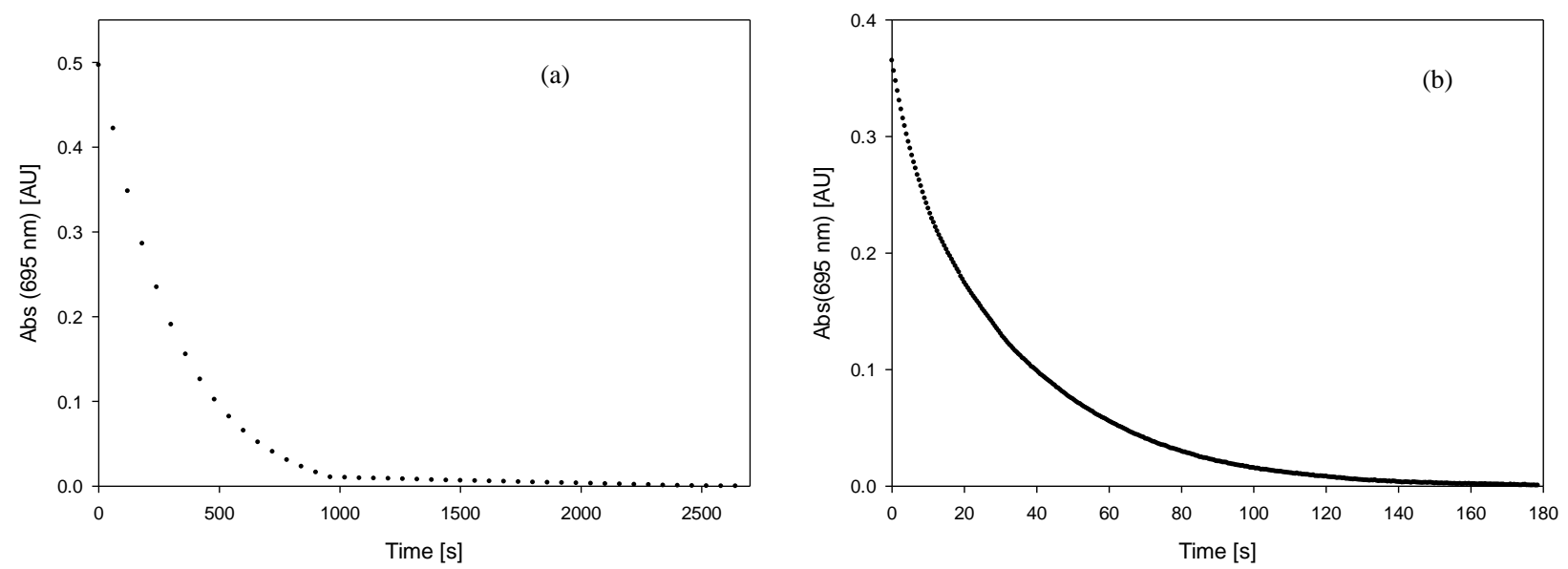

Figure S47. Decay of absorbance recorded at $695 \mathrm{~nm}$ in the oxidation of benzyl alcohol (30 $\mathrm{mM})$ with $\left[(\mathrm{N} 4 \mathrm{Py}) \mathrm{Fe}^{\mathrm{IV}}=\mathrm{O}\right]^{2+}(1.5 \mathrm{mM})(\mathrm{a})$ in the absence and (b) in the presence of $20 \mathrm{~mol} \%$ of NHPI in $\mathrm{CH}_{3} \mathrm{CN}$. 

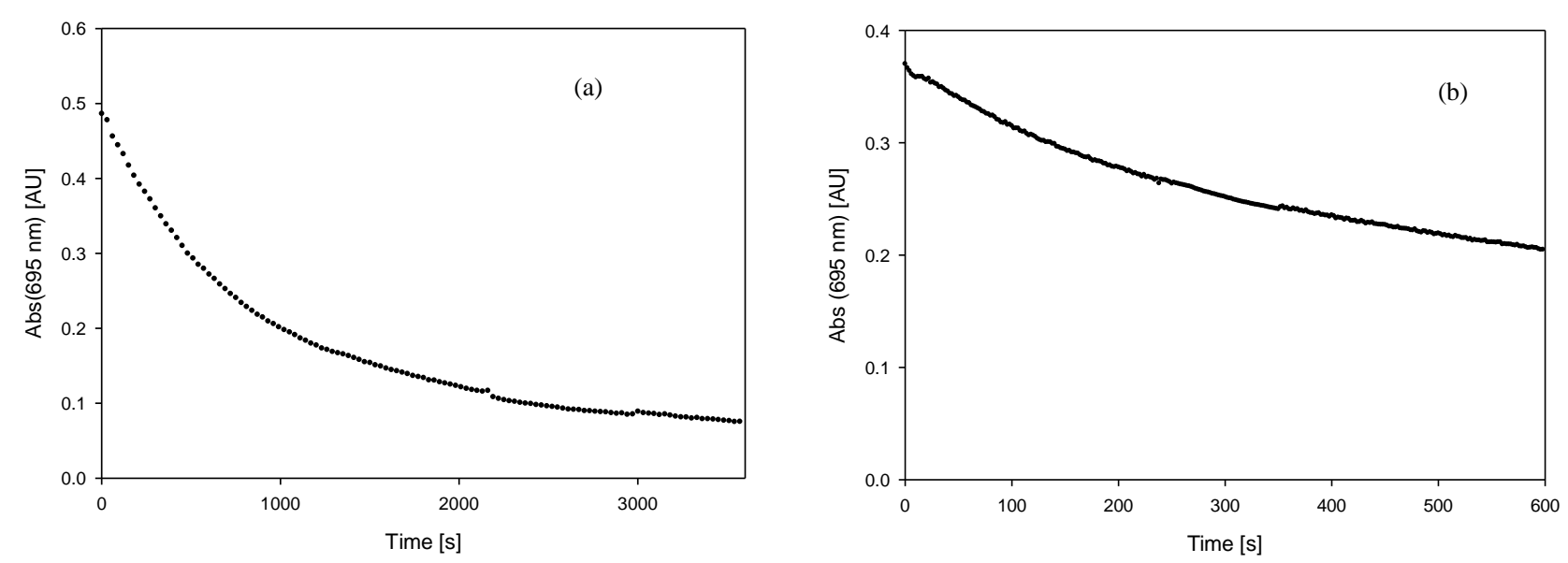

Figure S48. Decay of absorbance recorded at $695 \mathrm{~nm}$ in the oxidation of benzaldehyde $(30 \mathrm{mM})$ with $\left[(\mathrm{N} 4 \mathrm{Py}) \mathrm{Fe}^{\mathrm{IV}}=\mathrm{O}\right]^{2+}(1.5 \mathrm{mM})(\mathrm{a})$ in the absence and (b) in the presence of $20 \mathrm{~mol} \%$ of NHPI in $\mathrm{CH}_{3} \mathrm{CN}$.
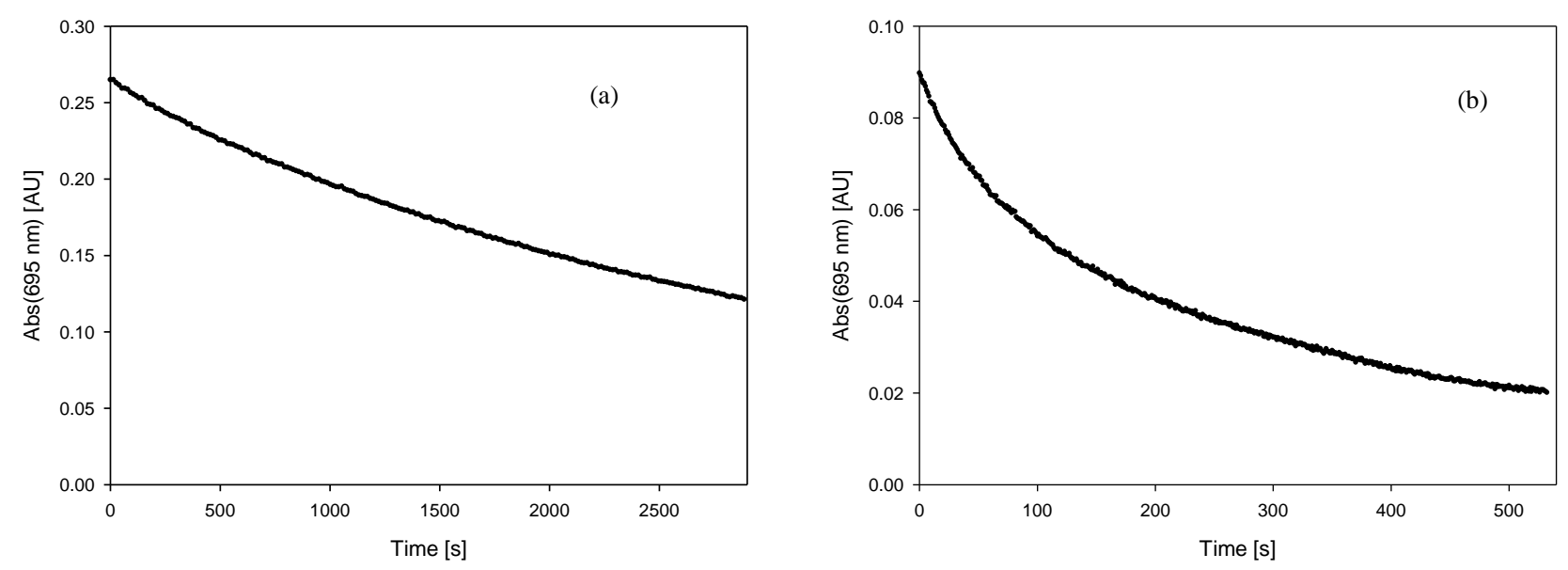

Figure S49. Decay of absorbance recorded at $695 \mathrm{~nm}$ in the oxidation of 1-(hexyloxy)hexane (250 $\mathrm{mM})$ with $\left[(\mathrm{N} 4 \mathrm{Py}) \mathrm{Fe}^{\mathrm{IV}}=\mathrm{O}\right]^{2+}(1.5 \mathrm{mM})(\mathrm{a})$ in the absence and (b) in the presence of $20 \mathrm{~mol} \%$ of NHPI in $\mathrm{CH}_{3} \mathrm{CN}$. 

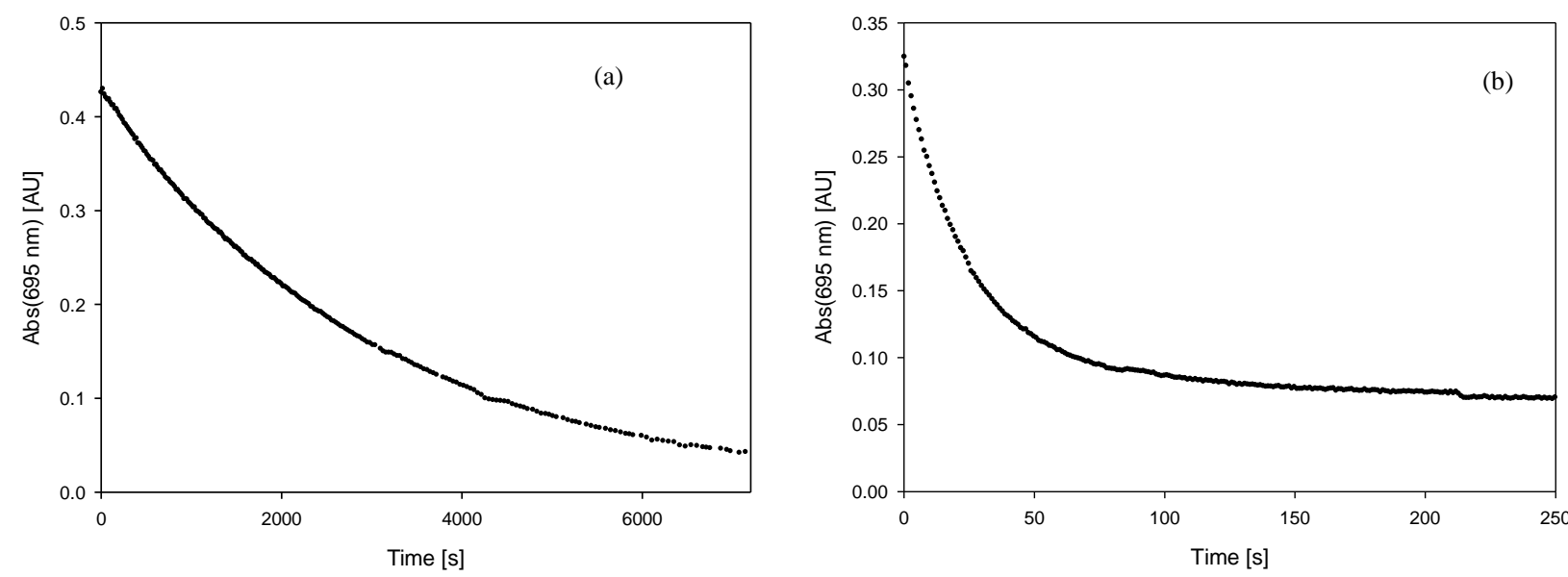

Figure S50. Decay of absorbance recorded at $695 \mathrm{~nm}$ in the oxidation of tetrahydrofuran $(200 \mathrm{mM})$ with $\left[(\mathrm{N} 4 \mathrm{Py}) \mathrm{Fe}^{\mathrm{IV}}=\mathrm{O}\right]^{2+}(1.5 \mathrm{mM})(\mathrm{a})$ in the absence and $(\mathrm{b})$ in the presence of $20 \mathrm{~mol} \%$ of NHPI in $\mathrm{CH}_{3} \mathrm{CN}$.
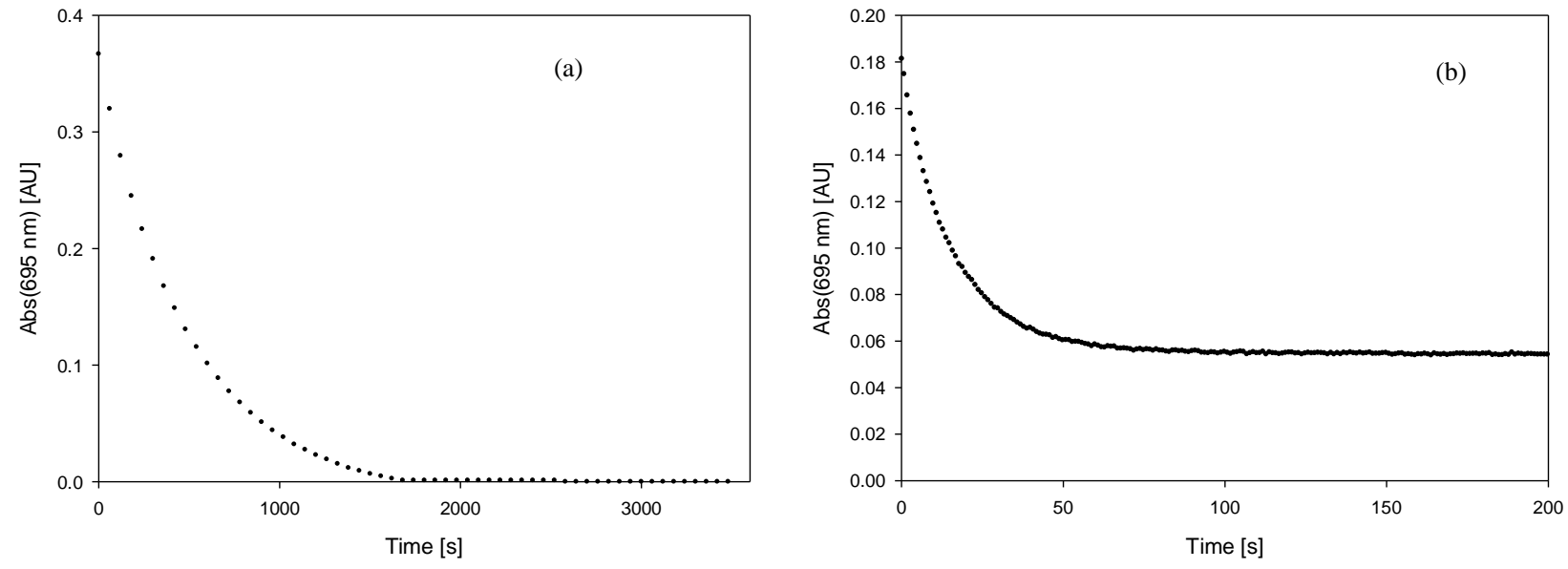

Figure S51. Decay of absorbance recorded at $695 \mathrm{~nm}$ in the oxidation of 4-(methoxy)benzyl methyl ether $(30 \mathrm{mM})$ with $\left[(\mathrm{N} 4 \mathrm{Py}) \mathrm{Fe}^{\mathrm{IV}}=\mathrm{O}\right]^{2+}(1.5 \mathrm{mM})(\mathrm{a})$ in the absence and (b) in the presence of 20 mol\% of NHPI in $\mathrm{CH}_{3} \mathrm{CN}$. 

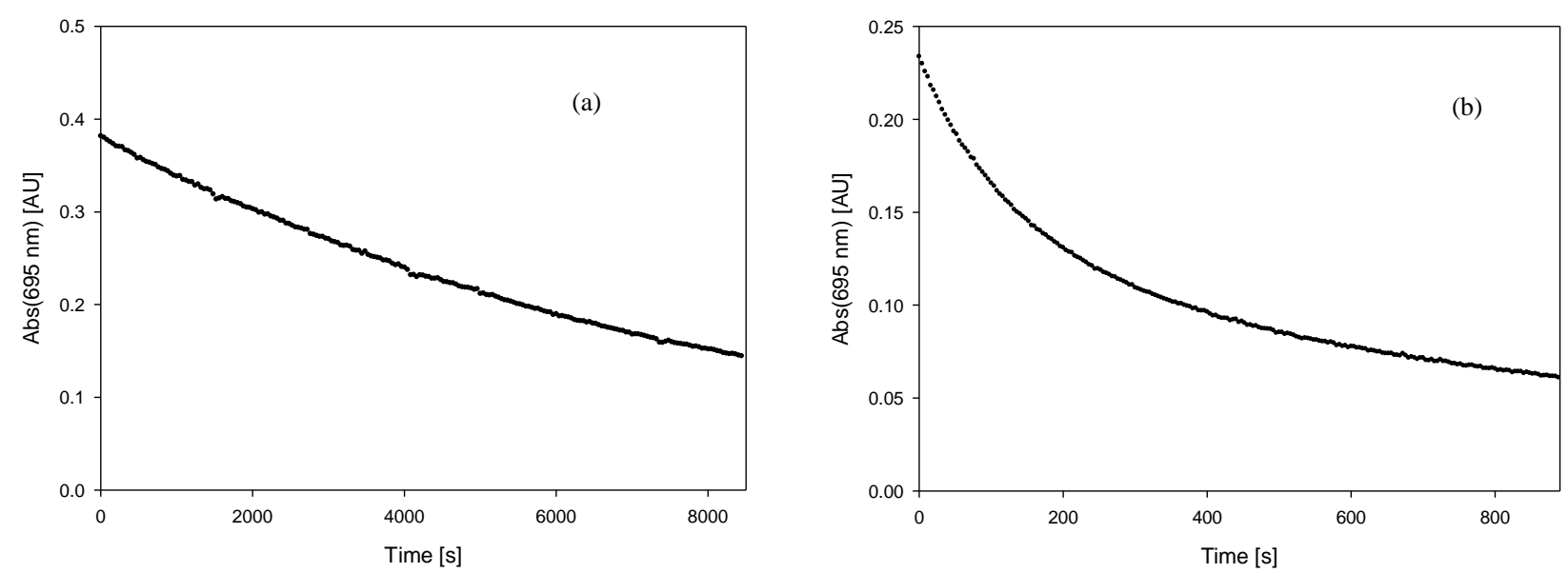

Figure S52. Decay of absorbance recorded at $695 \mathrm{~nm}$ in the oxidation of $N, N$-dimethylacetamide $(400 \mathrm{mM})$ with $\left[(\mathrm{N} 4 \mathrm{Py}) \mathrm{Fe}^{\mathrm{IV}}=\mathrm{O}\right]^{2+}(1.5 \mathrm{mM})(\mathrm{a})$ in the absence and (b) in the presence of $20 \mathrm{~mol} \%$ of NHPI in $\mathrm{CH}_{3} \mathrm{CN}$.
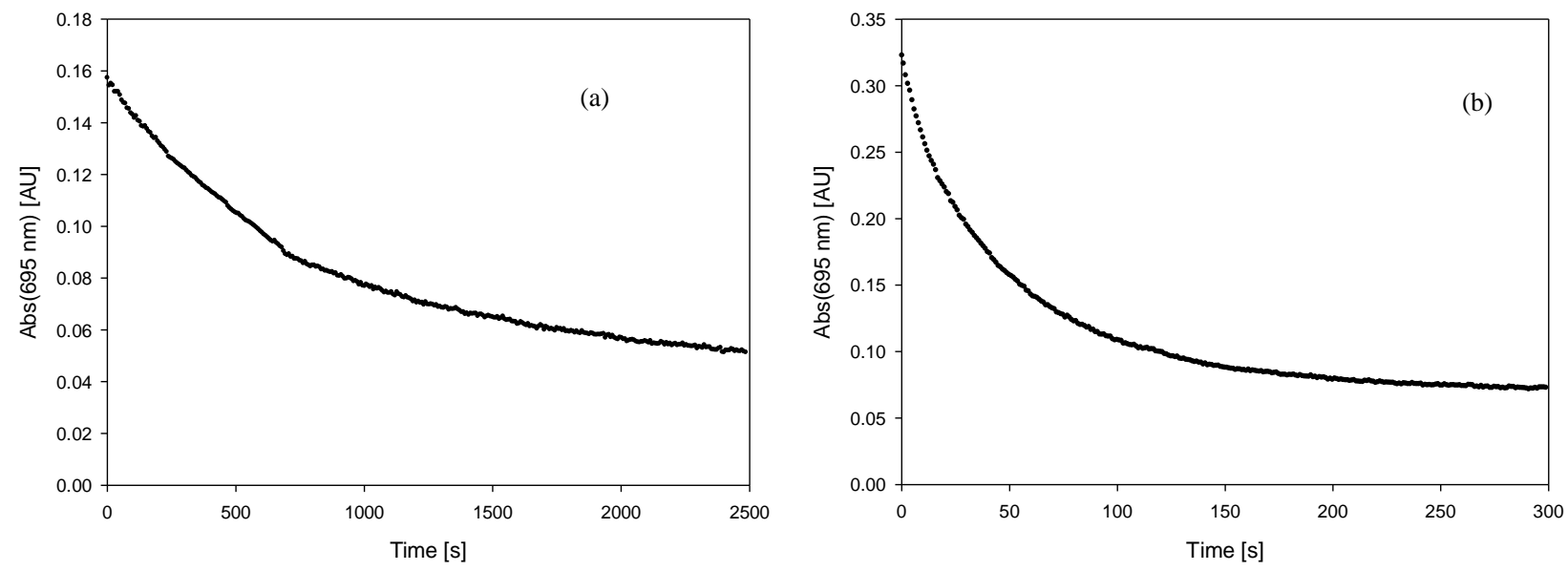

Figure S53. Decay of absorbance recorded at $695 \mathrm{~nm}$ in the oxidation of $N$-formylpyrrolidine (400 $\mathrm{mM})$ with $\left[(\mathrm{N} 4 \mathrm{Py}) \mathrm{Fe}^{\mathrm{IV}}=\mathrm{O}\right]^{2+}(1.5 \mathrm{mM})(\mathrm{a})$ in the absence and (b) in the presence of $20 \mathrm{~mol} \%$ of NHPI in $\mathrm{CH}_{3} \mathrm{CN}$. 

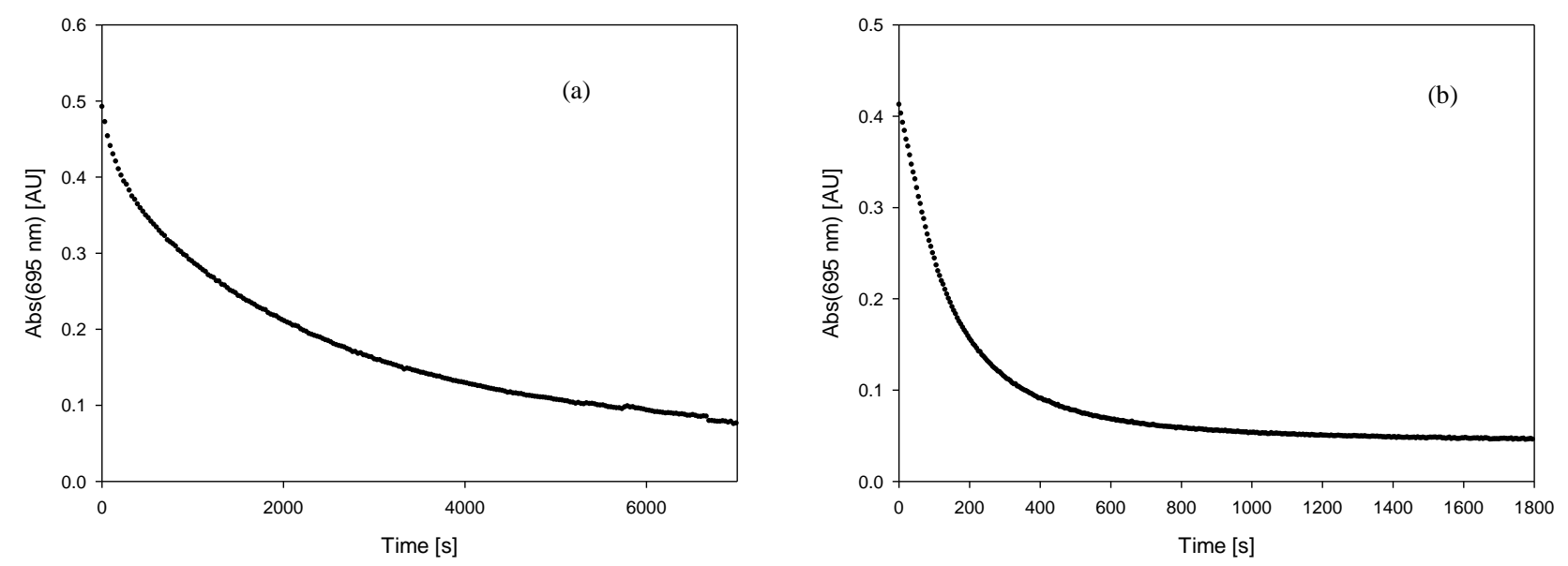

Figure S54. Decay of absorbance recorded at $695 \mathrm{~nm}$ in the oxidation of $N$-formylpiperidine (250 $\mathrm{mM})$ with $\left[(\mathrm{N} 4 \mathrm{Py}) \mathrm{Fe}^{\mathrm{IV}}=\mathrm{O}\right]^{2+}(1.5 \mathrm{mM})(\mathrm{a})$ in the absence and (b) in the presence of $20 \mathrm{~mol} \%$ of $\mathrm{NHPI}$ in $\mathrm{CH}_{3} \mathrm{CN}$.
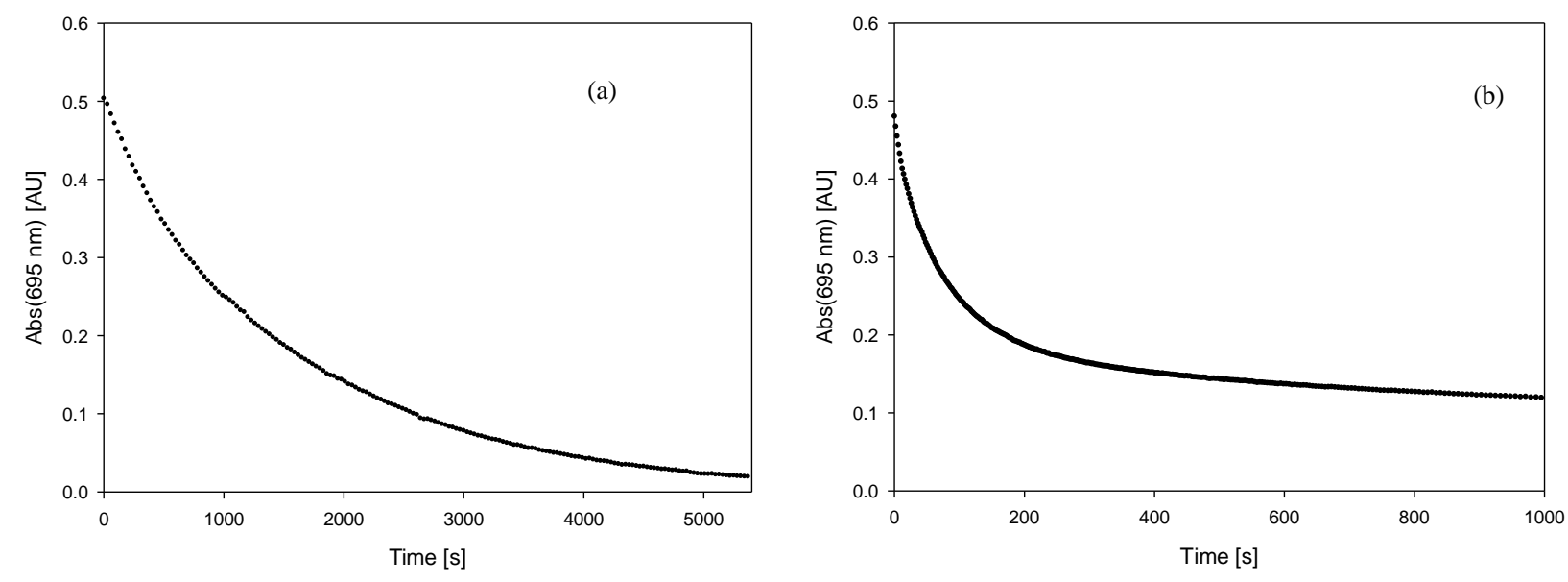

Figure S55. Decay of absorbance recorded at $695 \mathrm{~nm}$ in the oxidation of $N$-(4-chlorobenzyl)acetamide $(30 \mathrm{mM})$ with $\left[(\mathrm{N} 4 \mathrm{Py}) \mathrm{Fe}^{\mathrm{IV}}=\mathrm{O}\right]^{2+}(1.5 \mathrm{mM})$ (a) in the absence and (b) in the presence of $20 \mathrm{~mol} \%$ of NHPI in $\mathrm{CH}_{3} \mathrm{CN}$. 

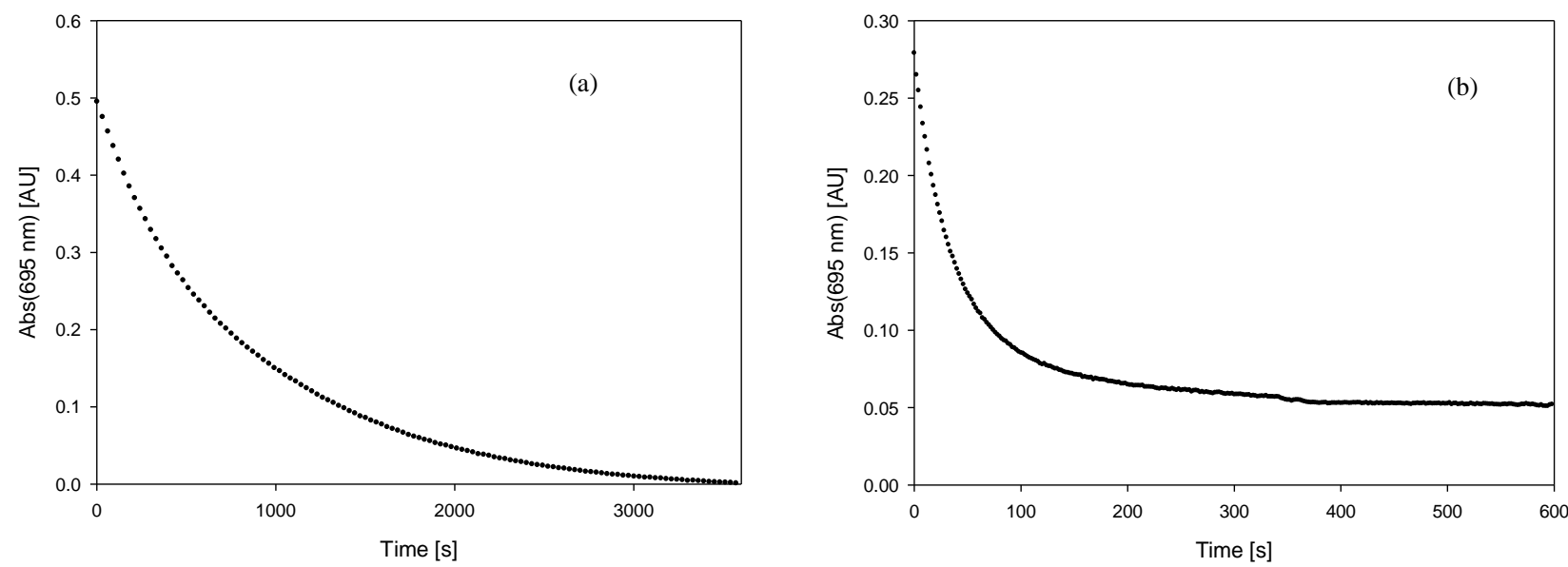

Figure S56. Decay of absorbance recorded at $695 \mathrm{~nm}$ in the oxidation of

$N$-(4-methylbenzyl)acetamide $(30 \mathrm{mM})$ with $\left[(\mathrm{N} 4 \mathrm{Py}) \mathrm{Fe}^{\mathrm{IV}}=\mathrm{O}\right]^{2+}(1.5 \mathrm{mM})(\mathrm{a})$ in the absence and (b) in the presence of $20 \mathrm{~mol} \%$ of NHPI in $\mathrm{CH}_{3} \mathrm{CN}$. 


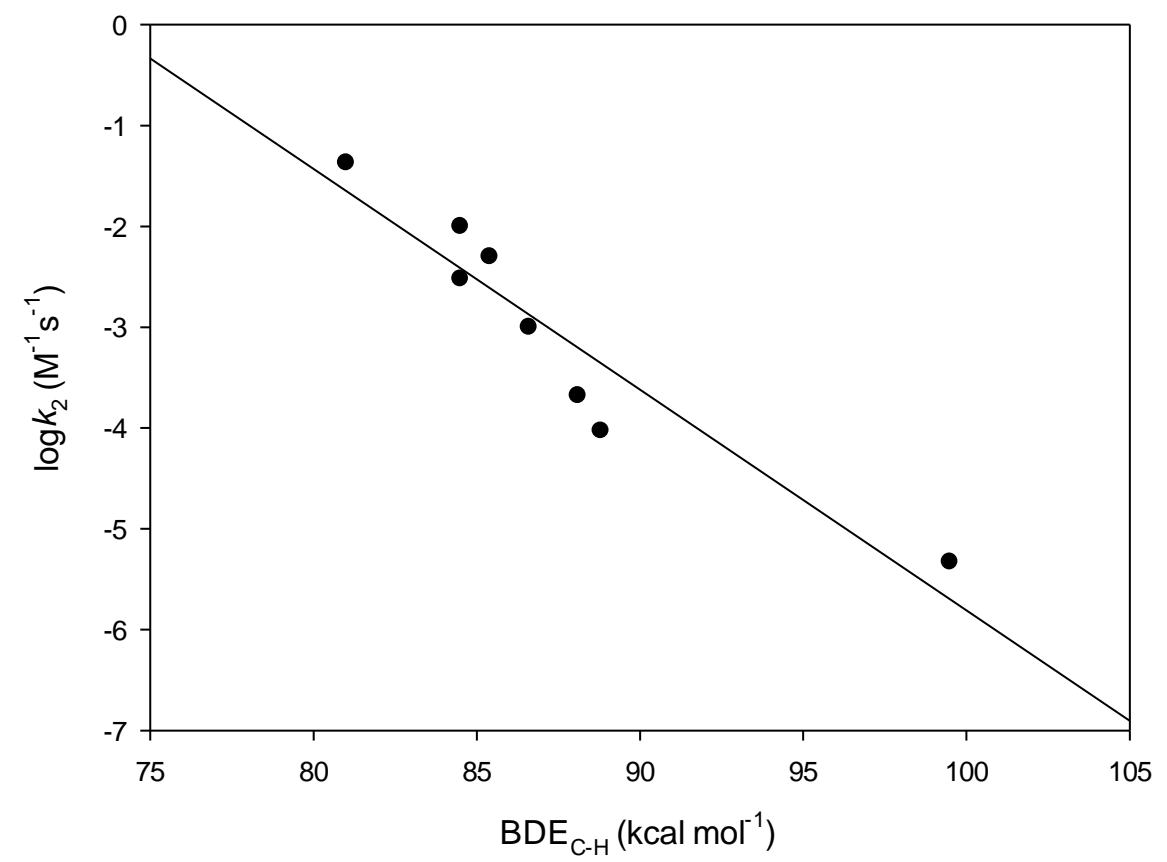

Figure S57. Correlation between $\log k_{2}$ for the reaction of hydrocarbons with $\left[(\mathrm{N} 4 \mathrm{Py}) \mathrm{Fe}^{\mathrm{IV}}=\mathrm{O}\right]^{2+}$ and the $\mathrm{C}-\mathrm{H}$ bond dissociation energies $\left(\mathrm{BDE}_{\mathrm{C}-\mathrm{H}}\right)$.

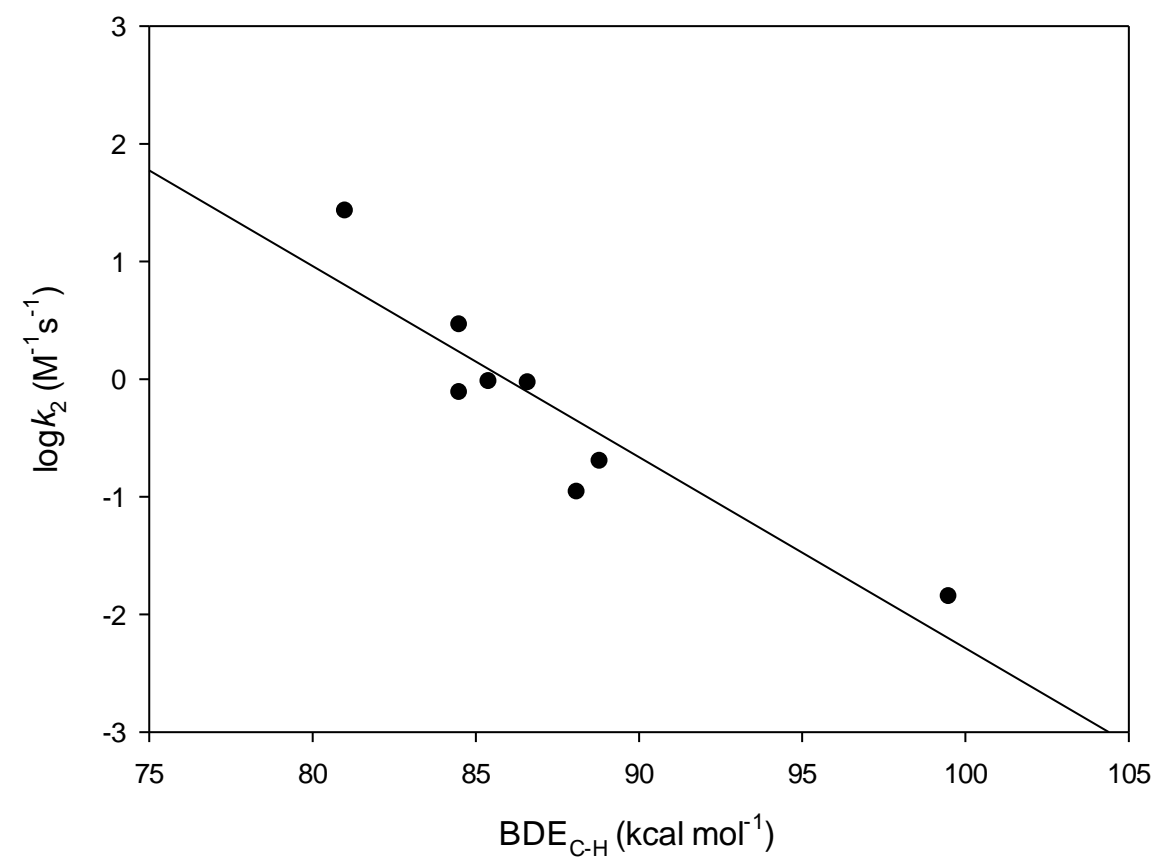

Figure S58. Correlation between $\log k_{2}$ for the reaction of hydrocarbons with PINO and the C-H bond dissociation energies $\left(\mathrm{BDE}_{\mathrm{C}-\mathrm{H}}\right)$. 


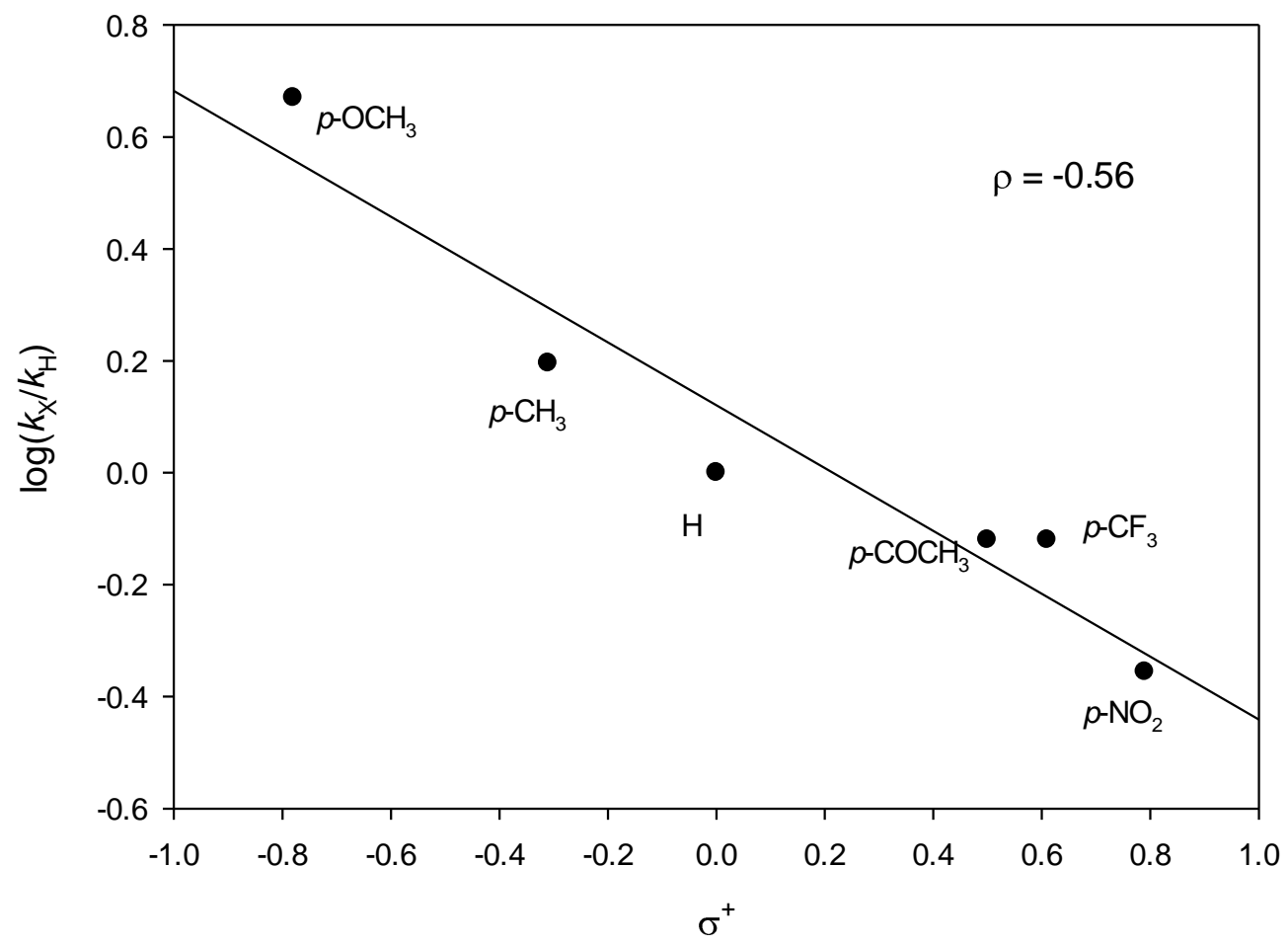

Figure S59. Hammett plot for the reaction of para-substituted toluenes with $\left[(\mathrm{N} 4 \mathrm{Py}) \mathrm{Fe}^{\mathrm{IV}}=\mathrm{O}\right]^{2+}$ in $\mathrm{CH}_{3} \mathrm{CN}$ at $25^{\circ} \mathrm{C}\left(\mathrm{r}^{2}=0.921\right)$.

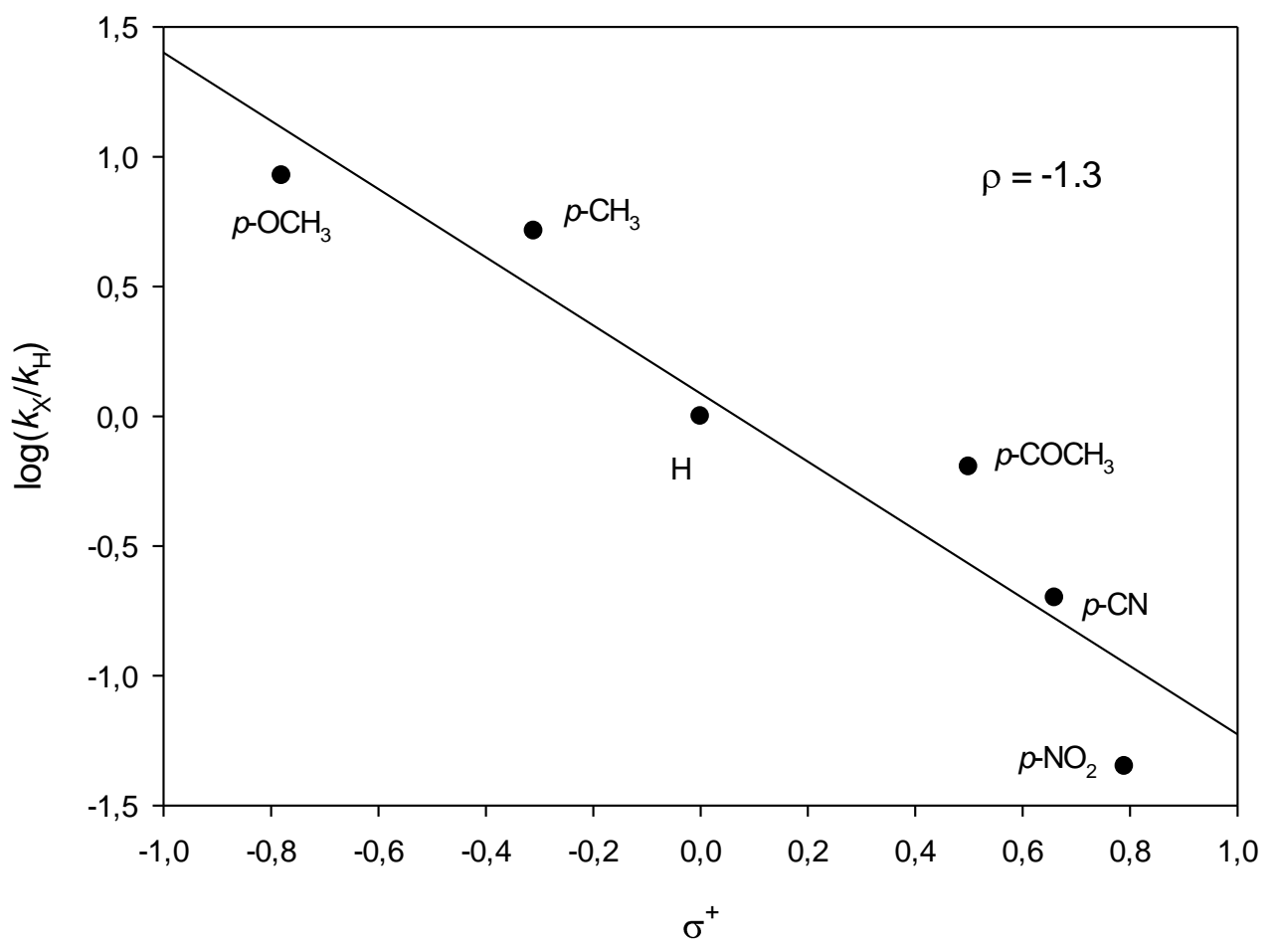

Figure S60. Hammett plot for the reaction of para-substituted toluenes with PINO in $\mathrm{CH}_{3} \mathrm{CN}$ at 25 ${ }^{\circ} \mathrm{C}\left(\mathrm{r}^{2}=0.892\right)$. 
GC analysis of the competitive intermolecular oxidation of aliphatic alcohols/alkylaromatics mixtures $(190 \mathrm{mM})$ promoted by $\left[(\mathrm{N} 4 \mathrm{Py}) \mathrm{Fe}^{\mathrm{IV}}=\mathrm{O}\right]^{2+}$ and $\left[(\mathrm{Bn}-\mathrm{TPEN}) \mathrm{Fe}^{\mathrm{IV}}=\mathrm{O}\right]^{2+}(19 \mathrm{mM})$ in the absence or presence of $20 \mathrm{~mol} \% \mathrm{NHPI}$ as mediator in $\mathrm{CH}_{3} \mathrm{CN}$.

ISTD

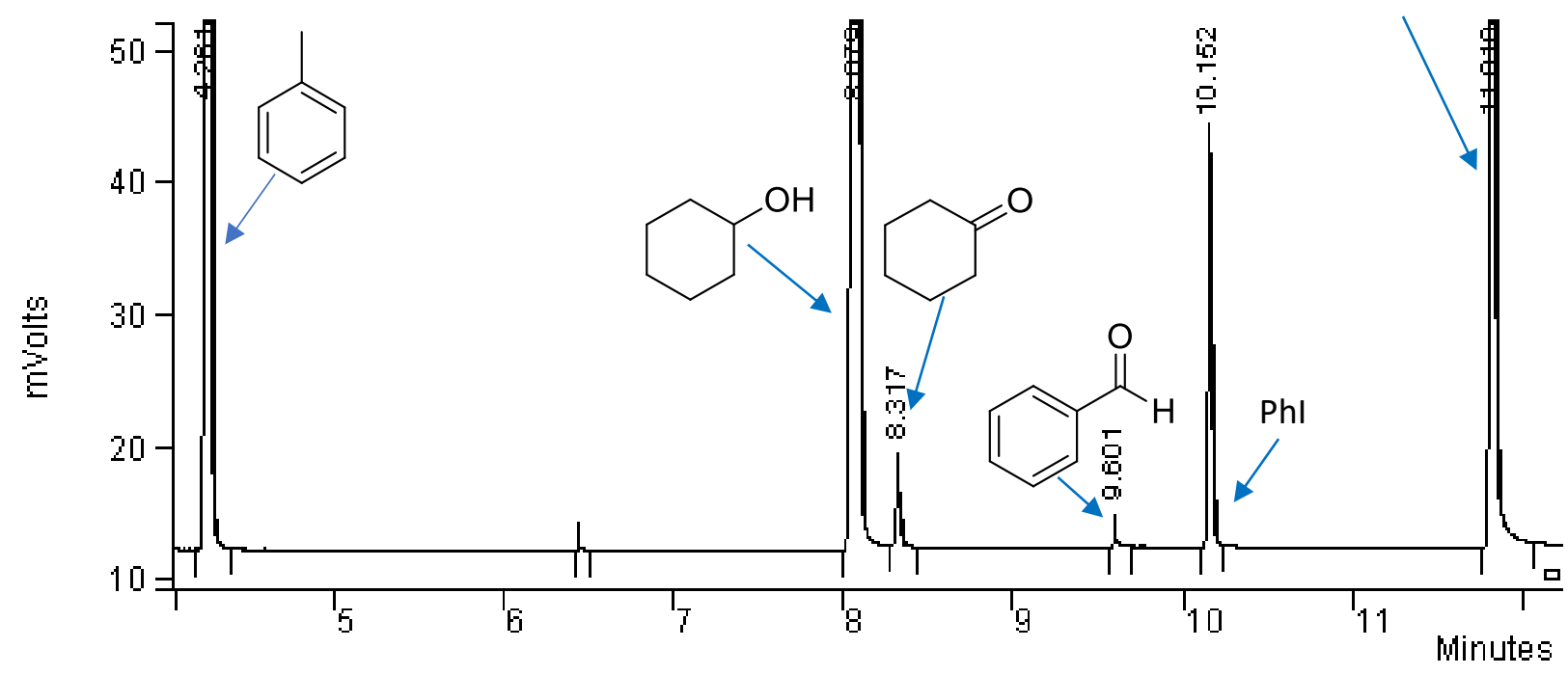

Figure S61. Chromatogram of competitive intermolecular oxidation of cyclohexanol and toluene with $\left[(\mathrm{N} 4 \mathrm{Py}) \mathrm{Fe}^{\mathrm{IV}}=\mathrm{O}^{2+}\right.$ in $\mathrm{CH}_{3} \mathrm{CN}$. Reaction time $1 \mathrm{~h}$.

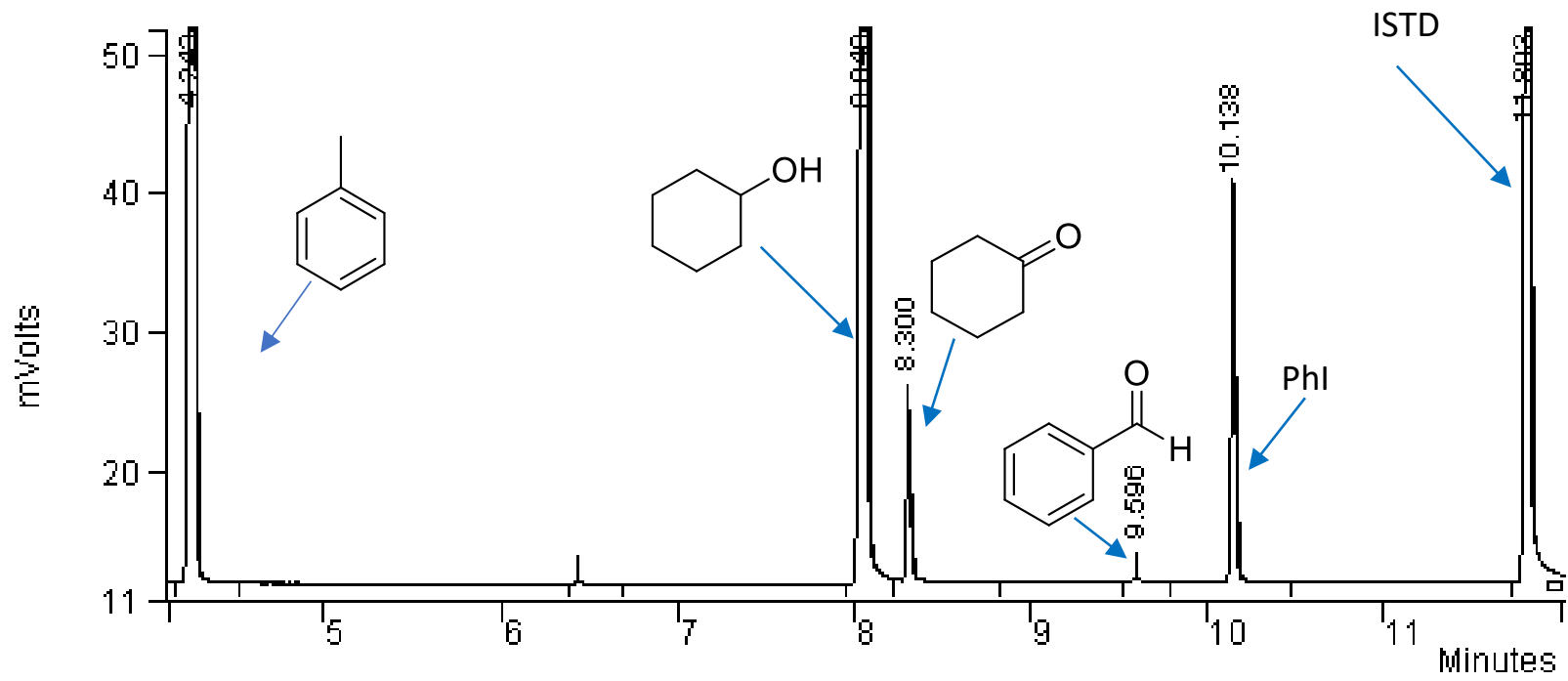

Figure S62. Chromatogram of competitive intermolecular oxidation of cyclohexanol and toluene with $\left[(\mathrm{N} 4 \mathrm{Py}) \mathrm{Fe}^{\mathrm{IV}}=\mathrm{O}\right]^{2+}$ in the presence of $20 \mathrm{~mol} \%$ NHPI as mediator in $\mathrm{CH}_{3} \mathrm{CN}$. Reaction time 1 h. 


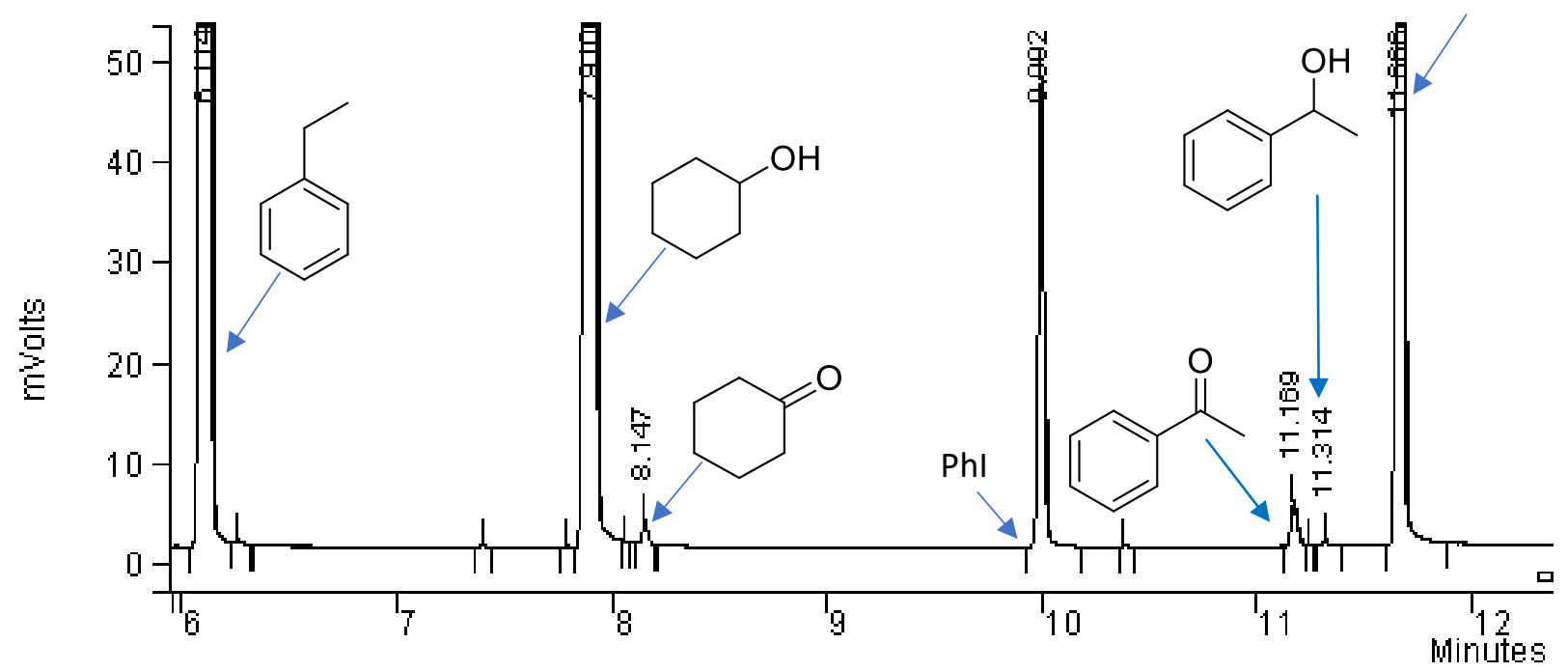

Figure S63. Chromatogram of competitive intermolecular oxidation of cyclohexanol and ethylbenzene with $\left[(\mathrm{N} 4 \mathrm{Py}) \mathrm{Fe}^{\mathrm{IV}}=\mathrm{O}\right]^{2+}$ in $\mathrm{CH}_{3} \mathrm{CN}$. Reaction time 5 min.

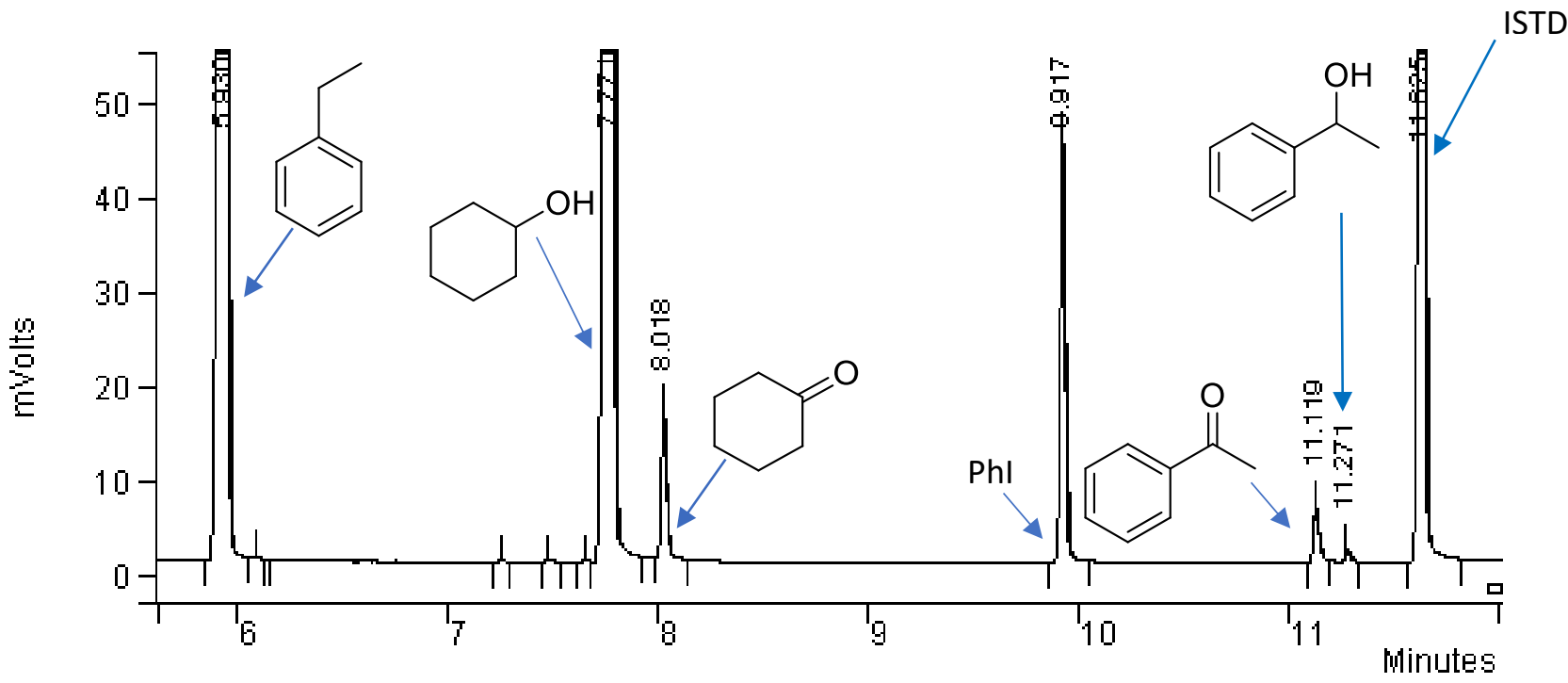

Figure S64. Chromatogram of competitive intermolecular oxidation of cyclohexanol and ethylbenzene with $\left[(\mathrm{N} 4 \mathrm{Py}) \mathrm{Fe}^{\mathrm{IV}}=\mathrm{O}\right]^{2+}$ in the presence of $20 \mathrm{~mol} \% \mathrm{NHPI}$ as mediator in $\mathrm{CH}_{3} \mathrm{CN}$. Reaction time 5 min. 


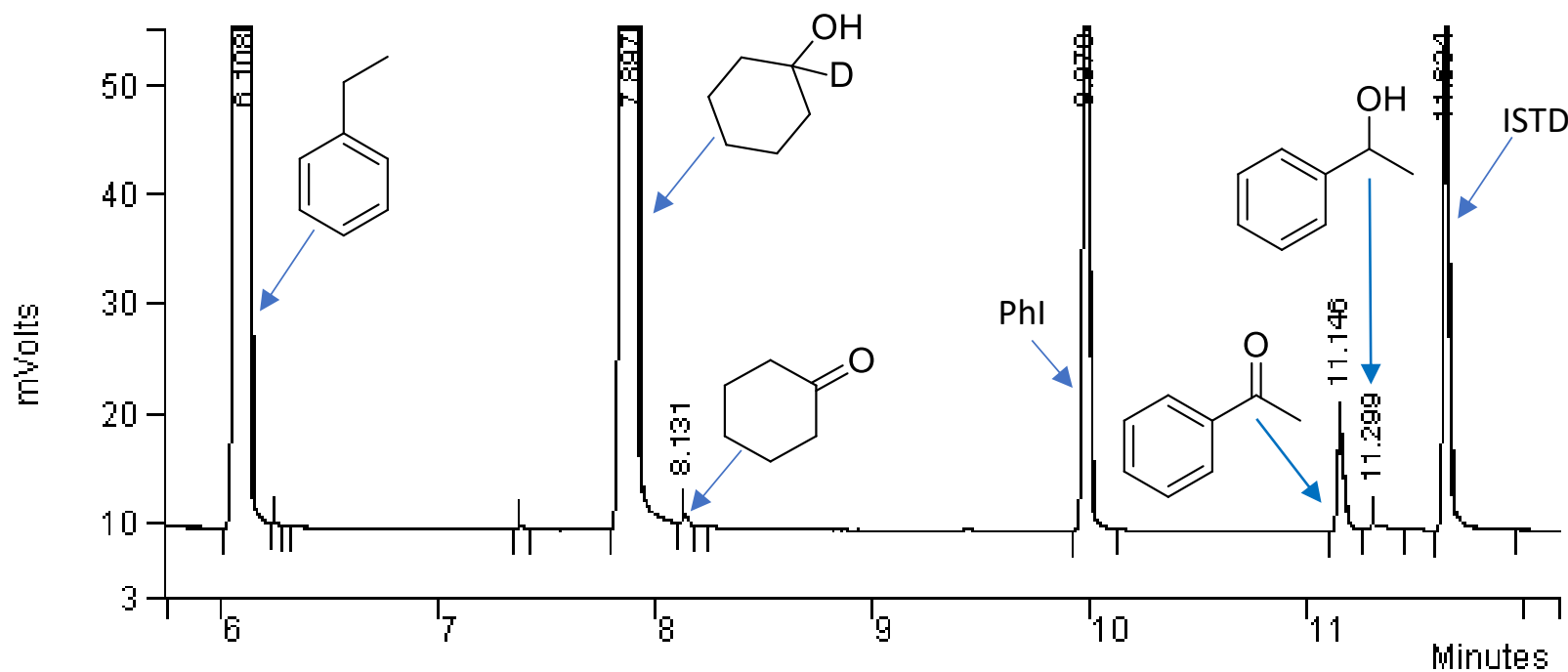

Figure S65. Chromatogram of competitive intermolecular oxidation of cyclohexanol- $d$ and ethylbenzene with $\left[(\mathrm{N} 4 \mathrm{Py}) \mathrm{Fe}^{\mathrm{IV}}=\mathrm{O}\right]^{2+}$ in $\mathrm{CH}_{3} \mathrm{CN}$. Reaction time 5 min.

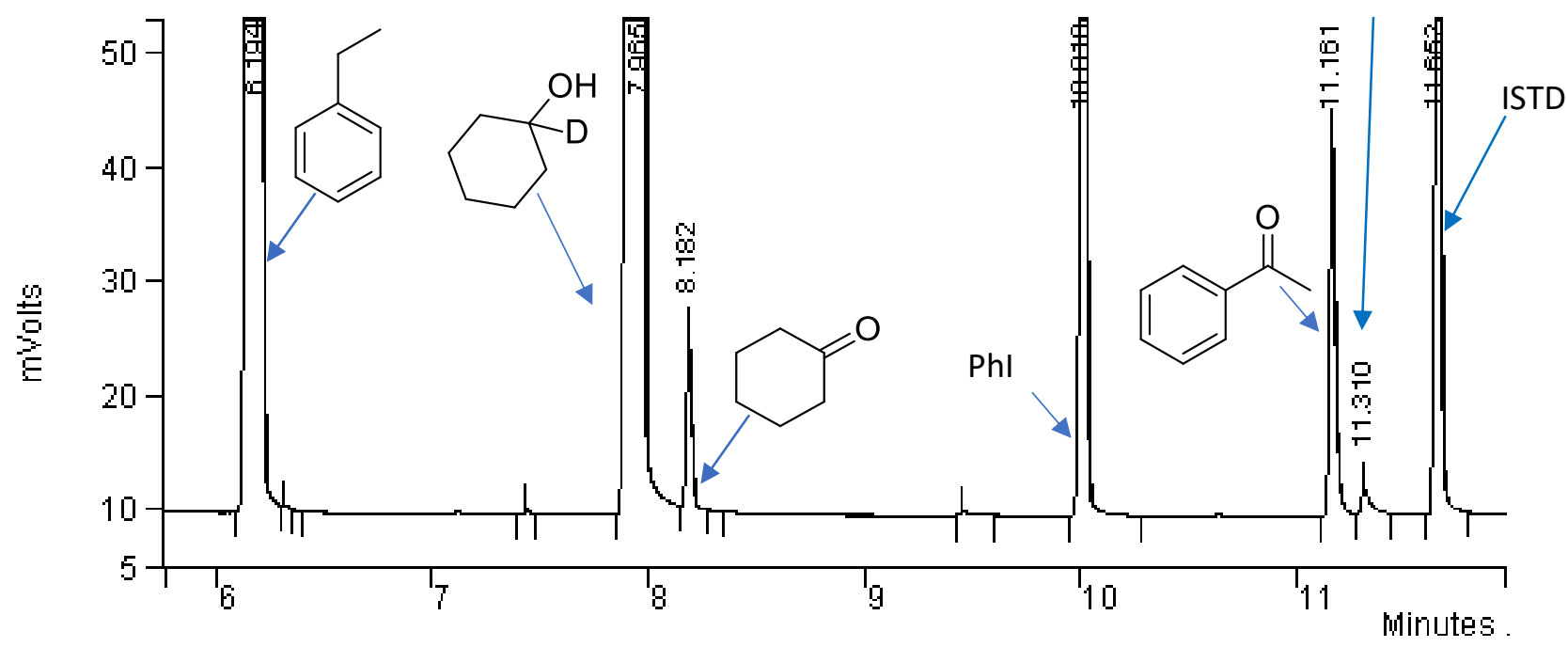

Figure S66. Chromatogram of competitive intermolecular oxidation of cyclohexanol- $d$ and ethylbenzene with $\left[(\mathrm{N} 4 \mathrm{Py}) \mathrm{Fe}^{\mathrm{IV}}=\mathrm{O}\right]^{2+}$ in the presence of $20 \mathrm{~mol} \% \mathrm{NHPI}$ as mediator in $\mathrm{CH}_{3} \mathrm{CN}$. Reaction time 5 min. 


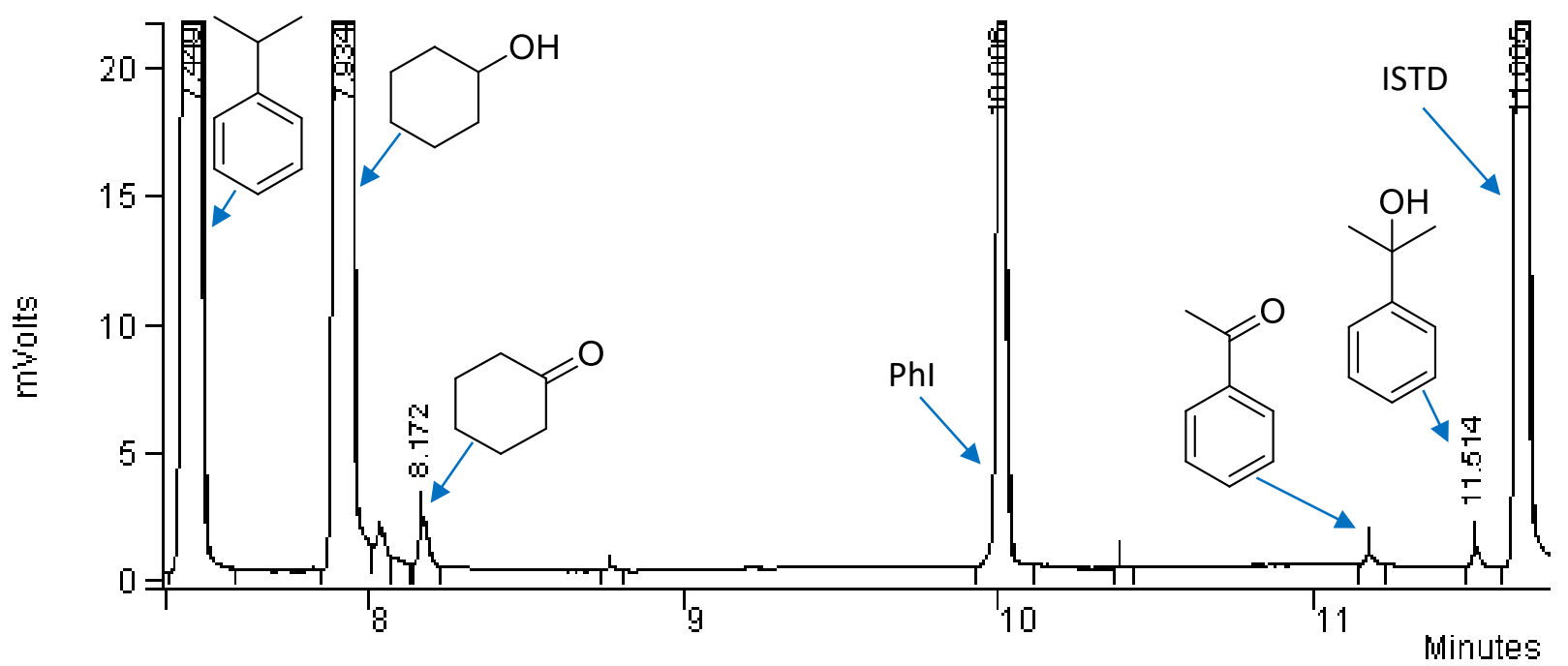

Figure S67. Chromatogram of competitive intermolecular oxidation of cyclohexanol and cumene with $\left[(\mathrm{N} 4 \mathrm{Py}) \mathrm{Fe}^{\mathrm{IV}}=\mathrm{O}\right]^{2+}$ in $\mathrm{CH}_{3} \mathrm{CN}$. Reaction time 5 min.

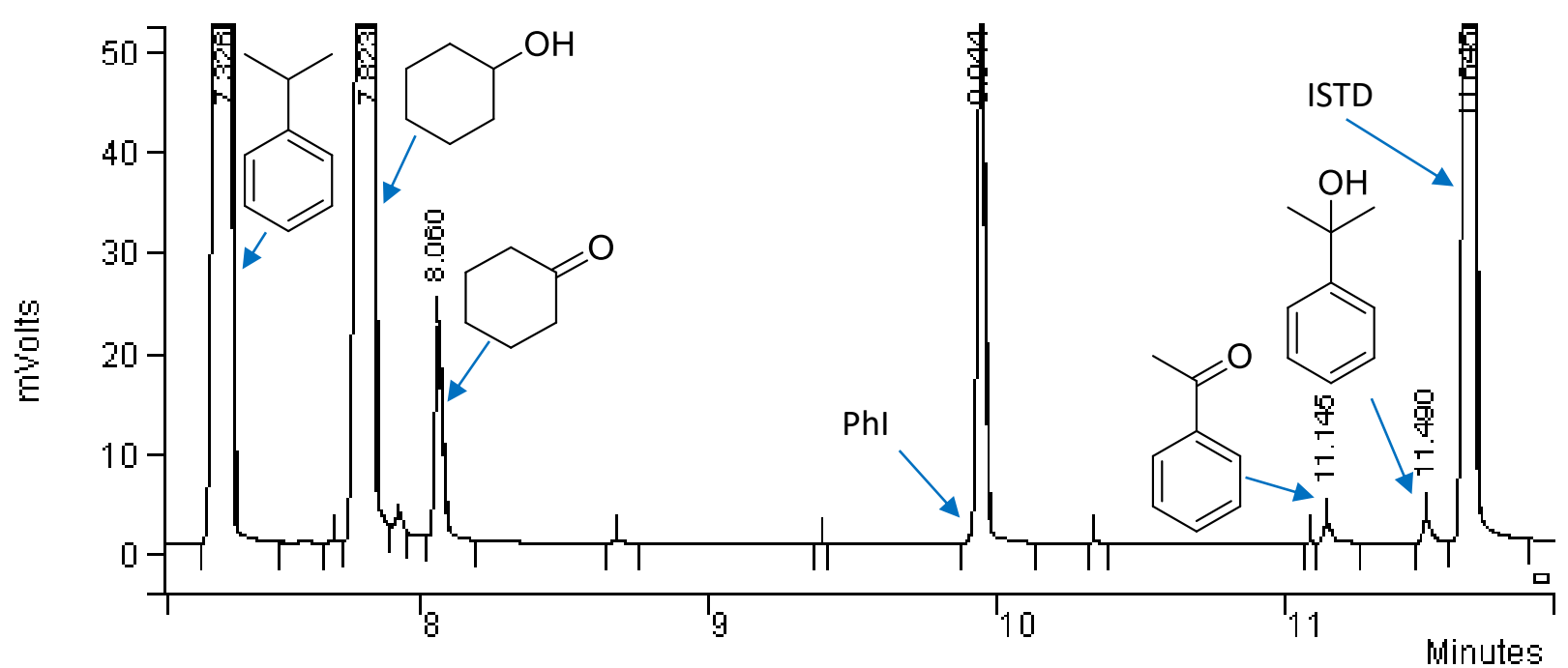

Figure S68. Chromatogram of competitive intermolecular oxidation of cyclohexanol and cumene with $\left[(\mathrm{N} 4 \mathrm{Py}) \mathrm{Fe}^{\mathrm{IV}}=\mathrm{O}\right]^{2+}$ in the presence of $20 \mathrm{~mol} \% \mathrm{NHPI}$ as mediator in $\mathrm{CH}_{3} \mathrm{CN}$. Reaction time 5 $\min$. 


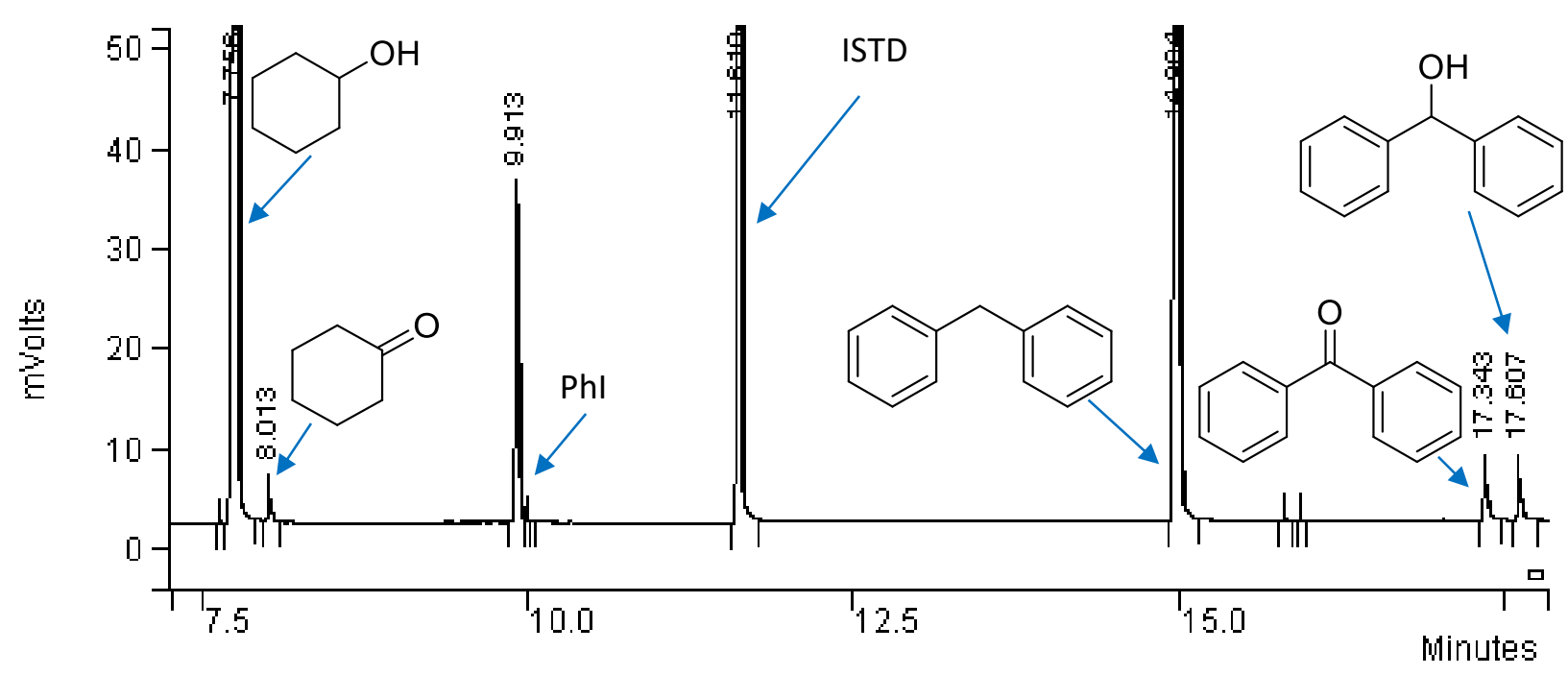

Figure S69. Chromatogram of competitive intermolecular oxidation of cyclohexanol and diphenylmethane with $\left[(\mathrm{N} 4 \mathrm{Py}) \mathrm{Fe}^{\mathrm{IV}}=\mathrm{O}^{2+}\right.$ in $\mathrm{CH}_{3} \mathrm{CN}$. Reaction time $5 \mathrm{~min}$.

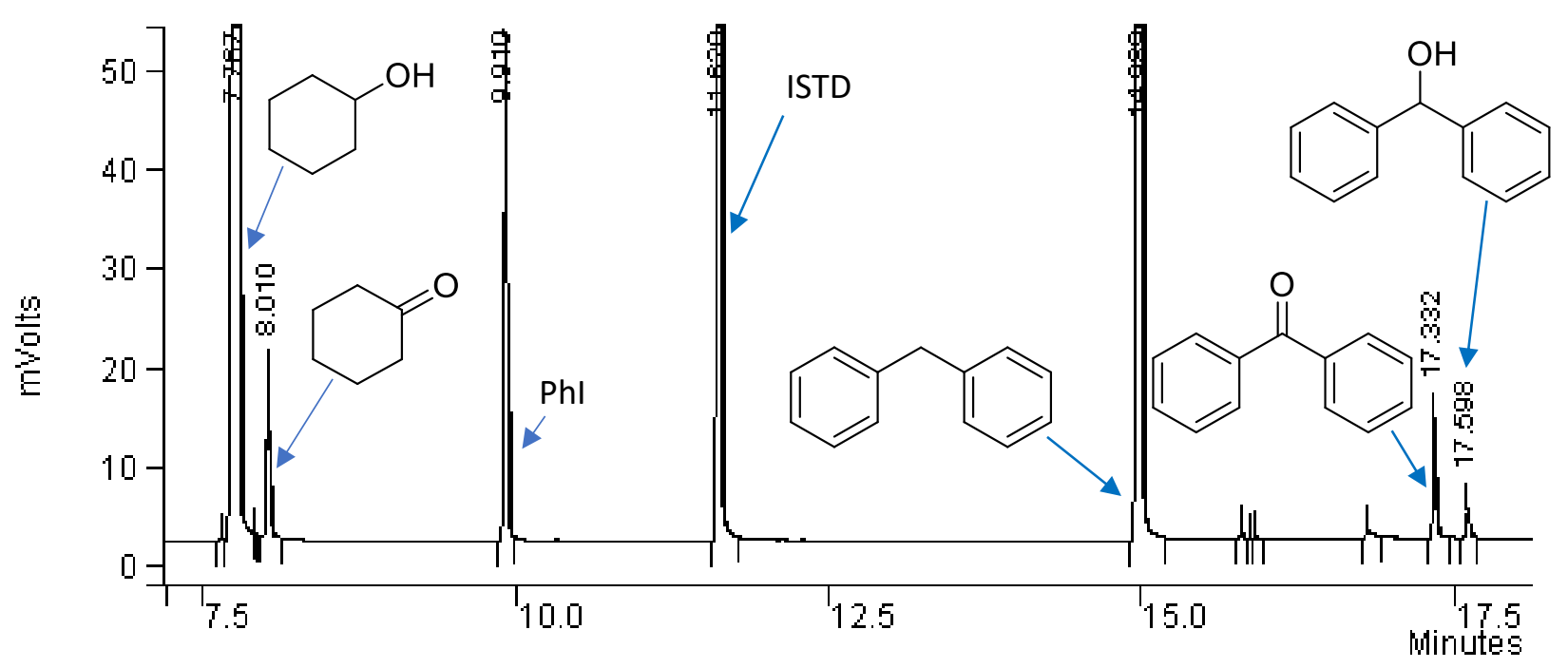

Figure S70. Chromatogram of competitive intermolecular oxidation of cyclohexanol and diphenylmethane with $\left[(\mathrm{N} 4 \mathrm{Py}) \mathrm{Fe}^{\mathrm{IV}}=\mathrm{O}^{2+}\right.$ in the presence of $20 \mathrm{~mol} \% \mathrm{NHPI}$ as mediator in $\mathrm{CH}_{3} \mathrm{CN}$. Reaction time 5 min. 


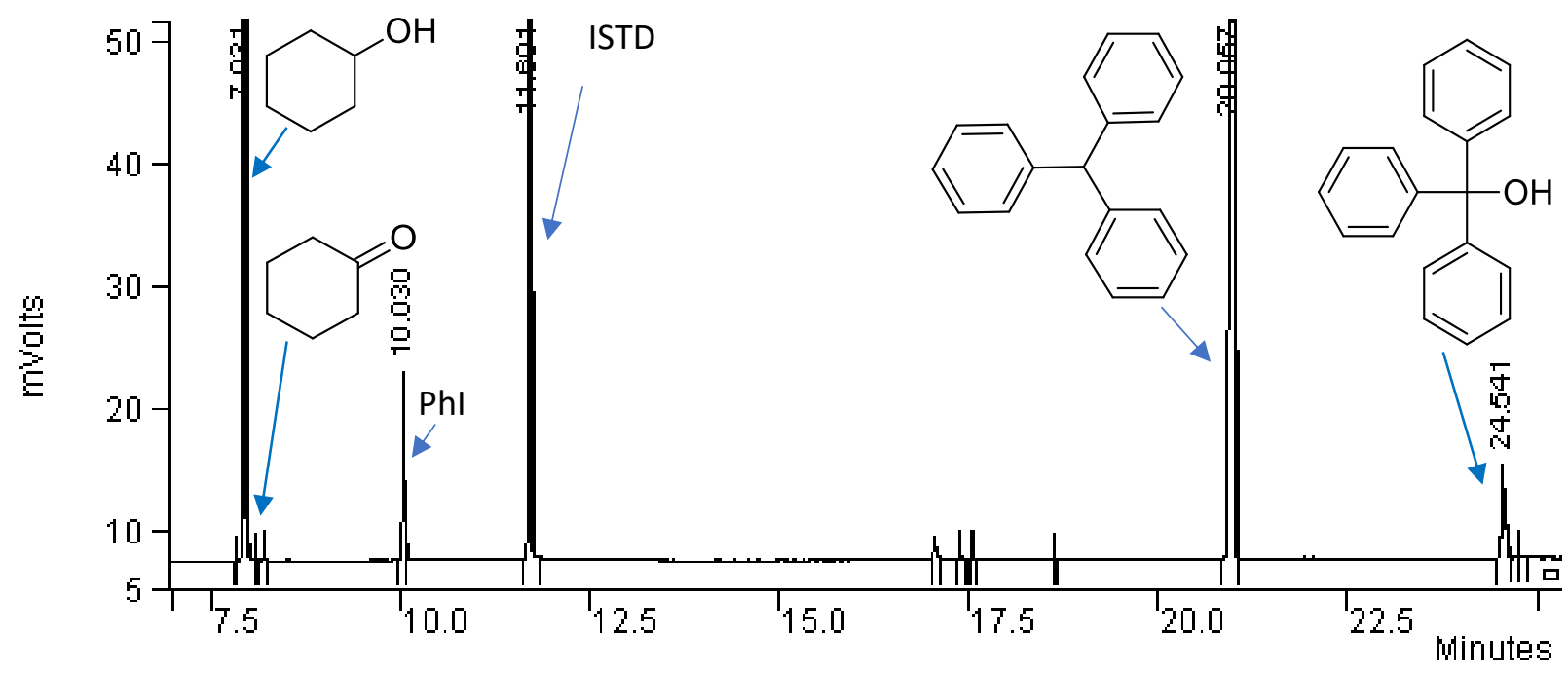

Figure S71. Chromatogram of competitive intermolecular oxidation of cyclohexanol and triphenylmethane with $\left[(\mathrm{N} 4 \mathrm{Py}) \mathrm{Fe}^{\mathrm{IV}}=\mathrm{O}\right]^{2+}$ in $\mathrm{CH}_{3} \mathrm{CN}$. Reaction time $5 \mathrm{~min}$.

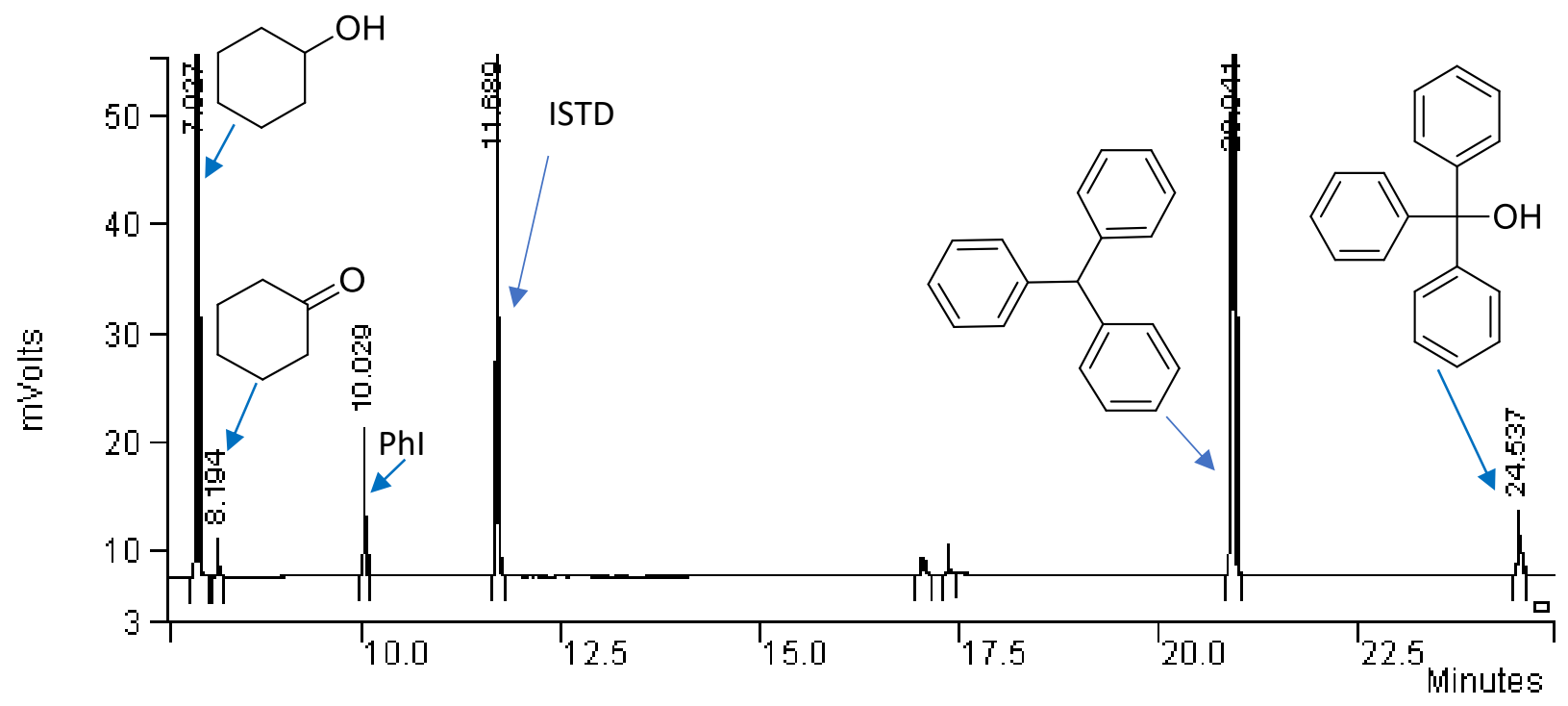

Figure S72. Chromatogram of competitive intermolecular oxidation of cyclohexanol and triphenylmethane with $\left[(\mathrm{N} 4 \mathrm{Py}) \mathrm{Fe}^{\mathrm{IV}}=\mathrm{O}\right]^{2+}$ in the presence of $20 \mathrm{~mol} \%$ NHPI as mediator in $\mathrm{CH}_{3} \mathrm{CN}$. Reaction time 5 min. 


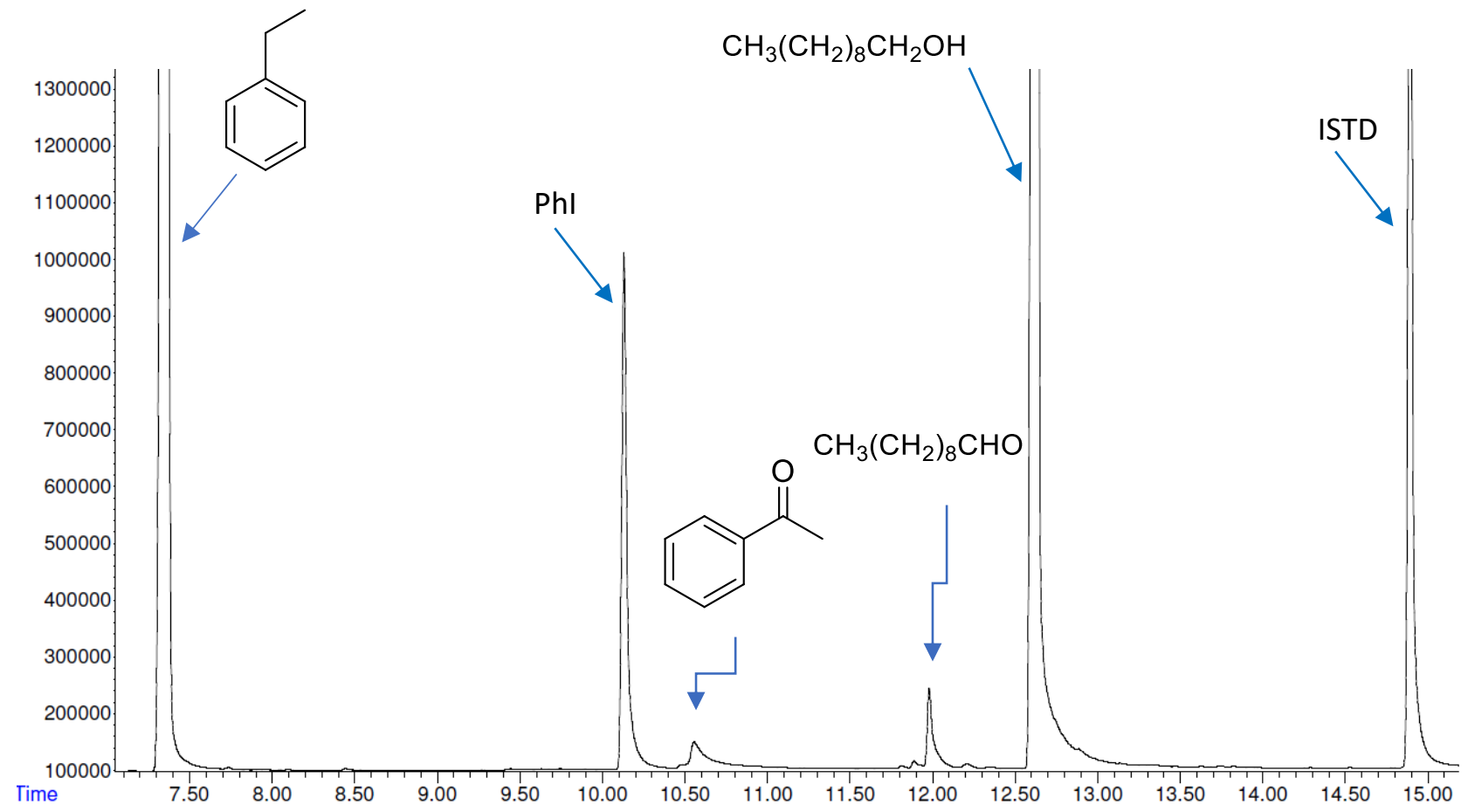

Figure S73. Chromatogram of competitive intermolecular oxidation of 1-decanol and Ethylbenzene with $\left[(\mathrm{N} 4 \mathrm{Py}) \mathrm{Fe}^{\mathrm{IV}}=\mathrm{O}\right]^{2+}$ in $\mathrm{CH}_{3} \mathrm{CN}$. Reaction time 5 min.

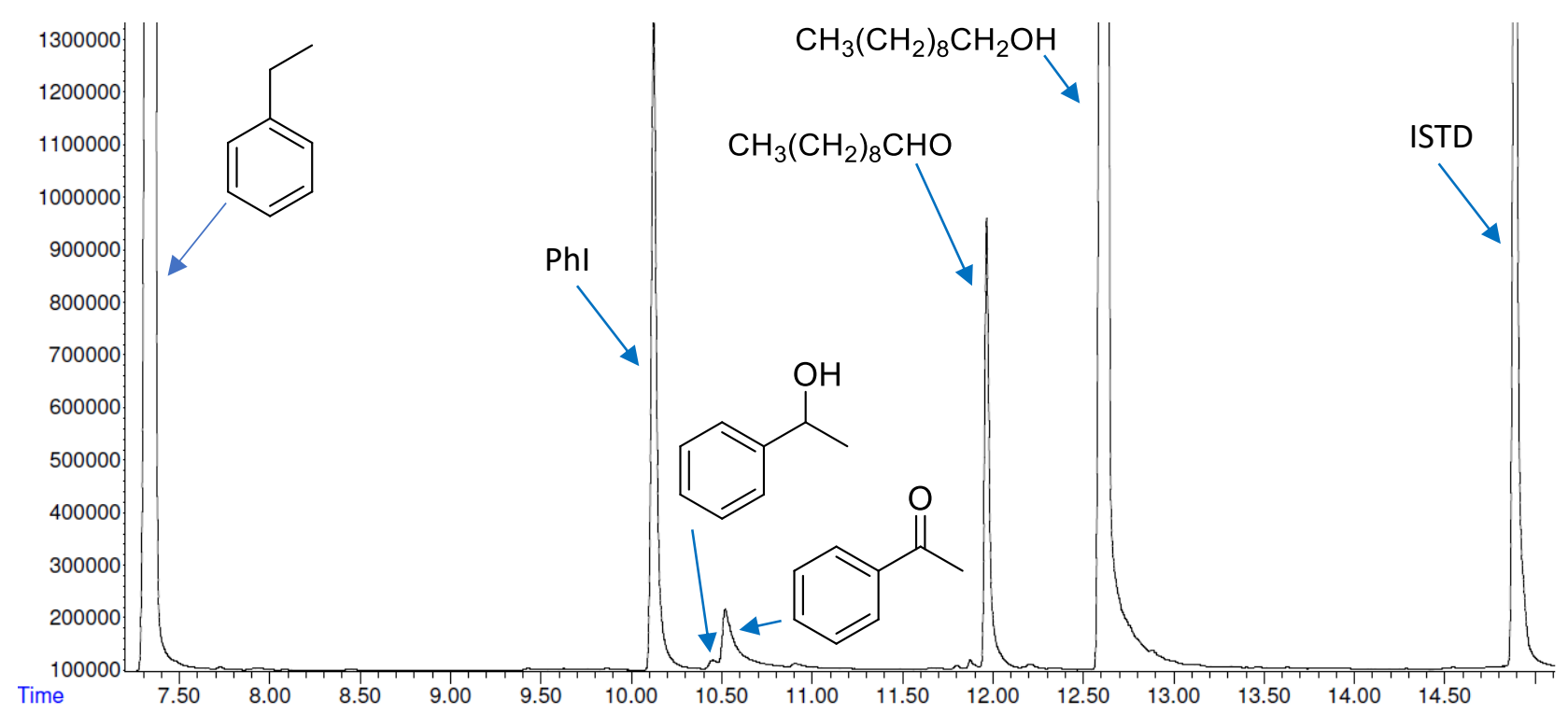

Figure S74. Chromatogram of competitive intermolecular oxidation of 1-decanol and Ethylbenzene with $\left[(\mathrm{N} 4 \mathrm{Py}) \mathrm{Fe}^{\mathrm{IV}}=\mathrm{O}\right]^{2+}$ in the presence of $20 \mathrm{~mol} \% \mathrm{NHPI}$ as mediator in $\mathrm{CH}_{3} \mathrm{CN}$. Reaction time 5 $\min$. 


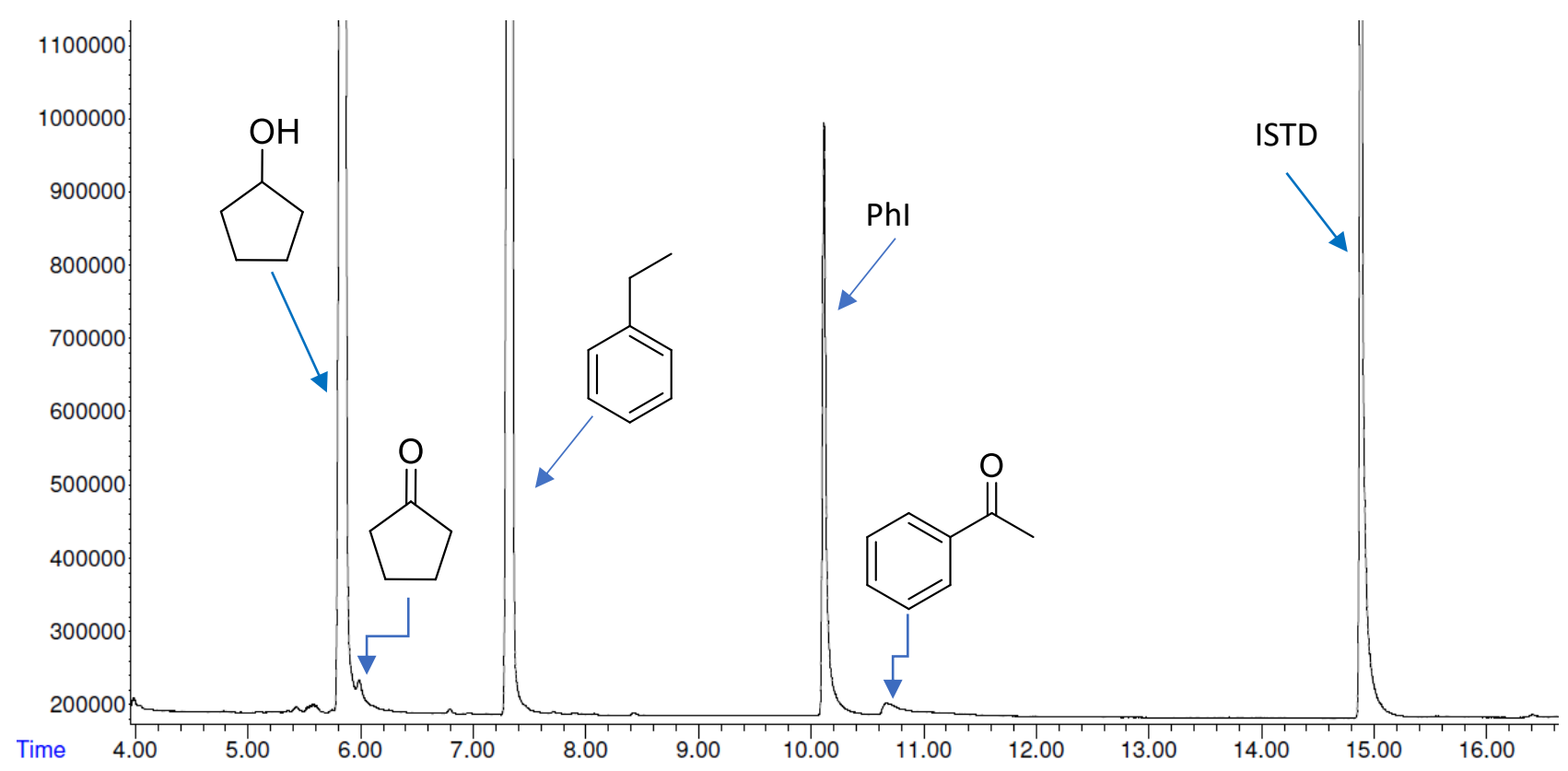

Figure S75. Chromatogram of competitive intermolecular oxidation of Cyclopentanol and Ethylbenzene with $\left[(\mathrm{N} 4 \mathrm{Py}) \mathrm{Fe}^{\mathrm{IV}}=\mathrm{O}^{2+}\right.$ in $\mathrm{CH}_{3} \mathrm{CN}$. Reaction time $5 \mathrm{~min}$.

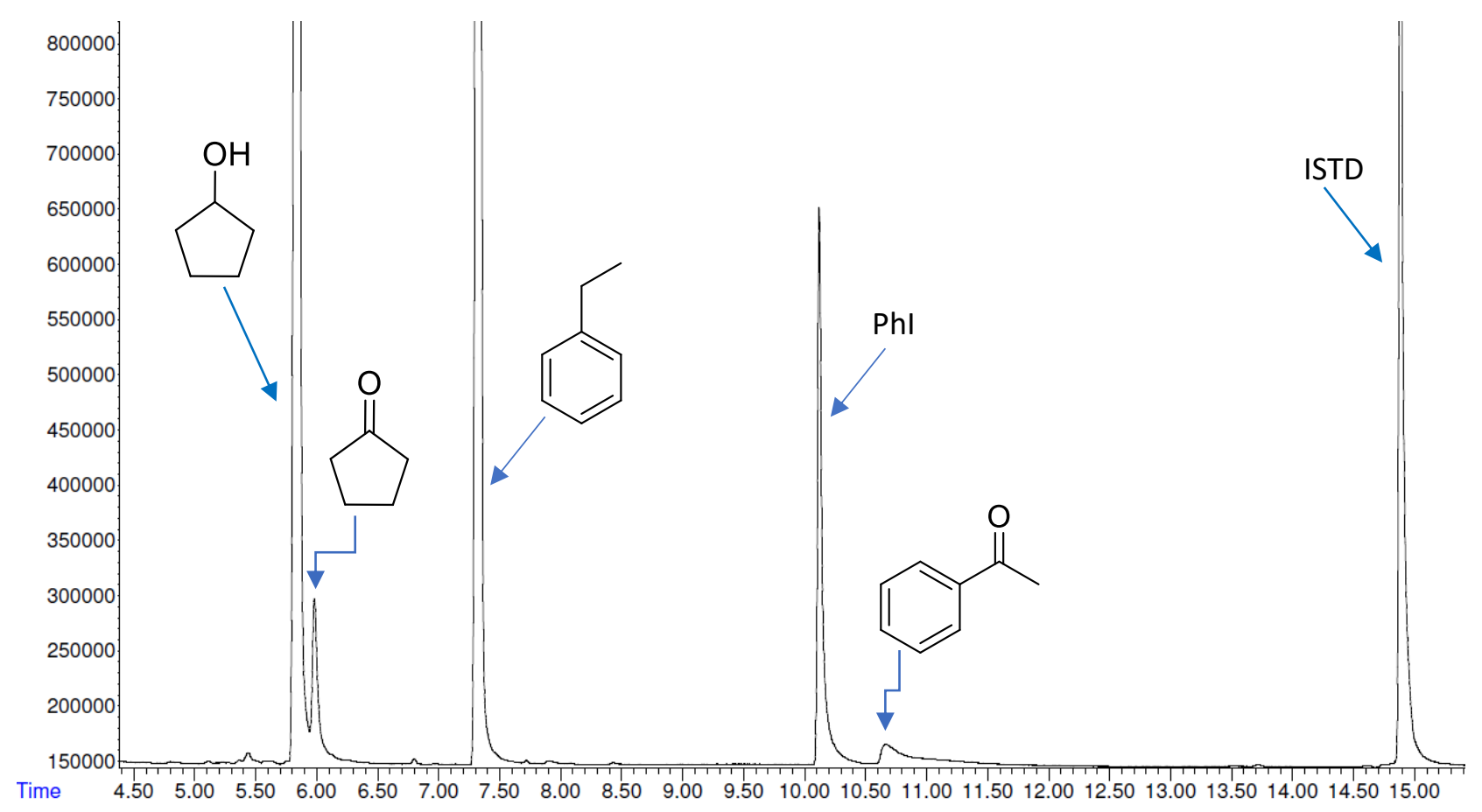

Figure S76. Chromatogram of competitive intermolecular oxidation of Cyclopentanol and Ethylbenzene with $\left[(\mathrm{N} 4 \mathrm{Py}) \mathrm{Fe}^{\mathrm{IV}}=\mathrm{O}^{2+}\right.$ in the presence of $20 \mathrm{~mol} \%$ NHPI as mediator in $\mathrm{CH}_{3} \mathrm{CN}$. Reaction time 5 min. 


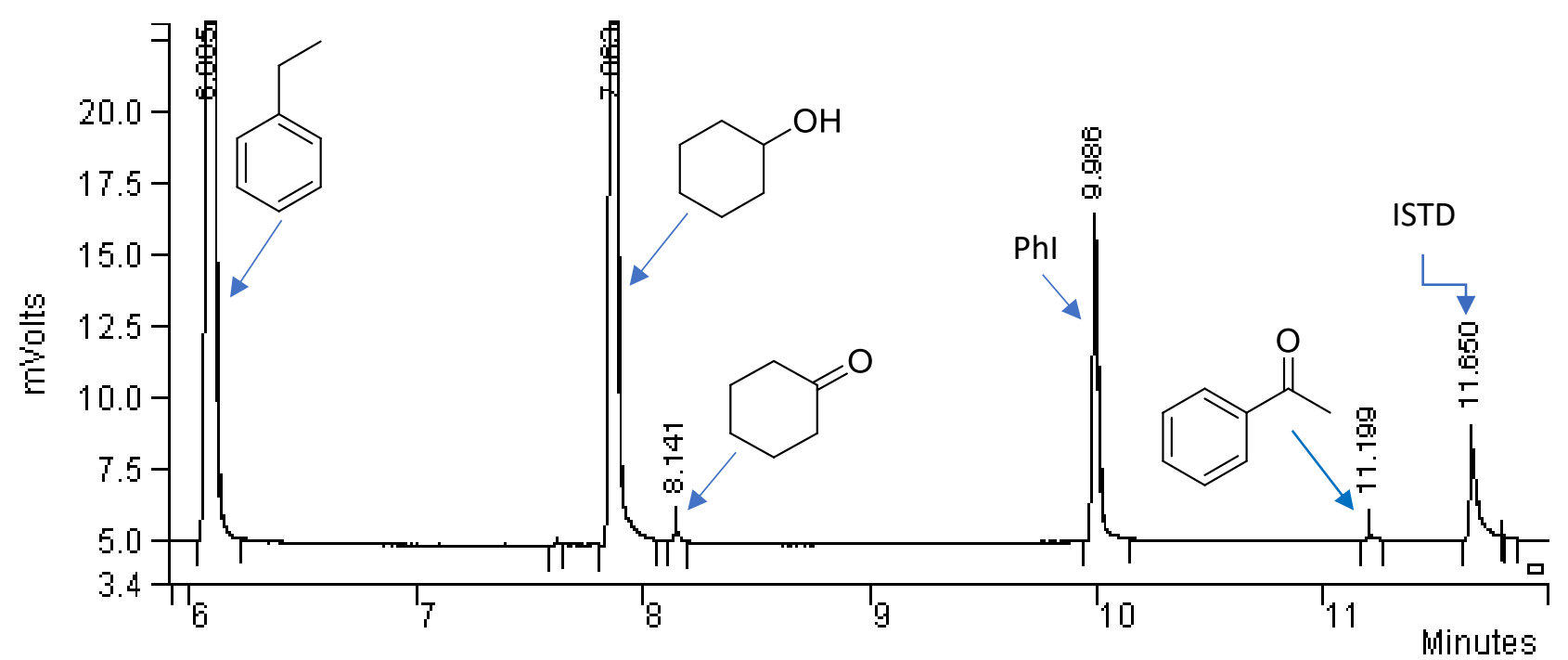

Figure S77. Chromatogram of competitive intermolecular oxidation of cyclohexanol and ethylbenzene with $\left[(\mathrm{Bn}-\mathrm{TPEN}) \mathrm{Fe}^{\mathrm{IV}}=\mathrm{O}\right]^{2+}$ in $\mathrm{CH}_{3} \mathrm{CN}$. Reaction time $5 \mathrm{~min}$.

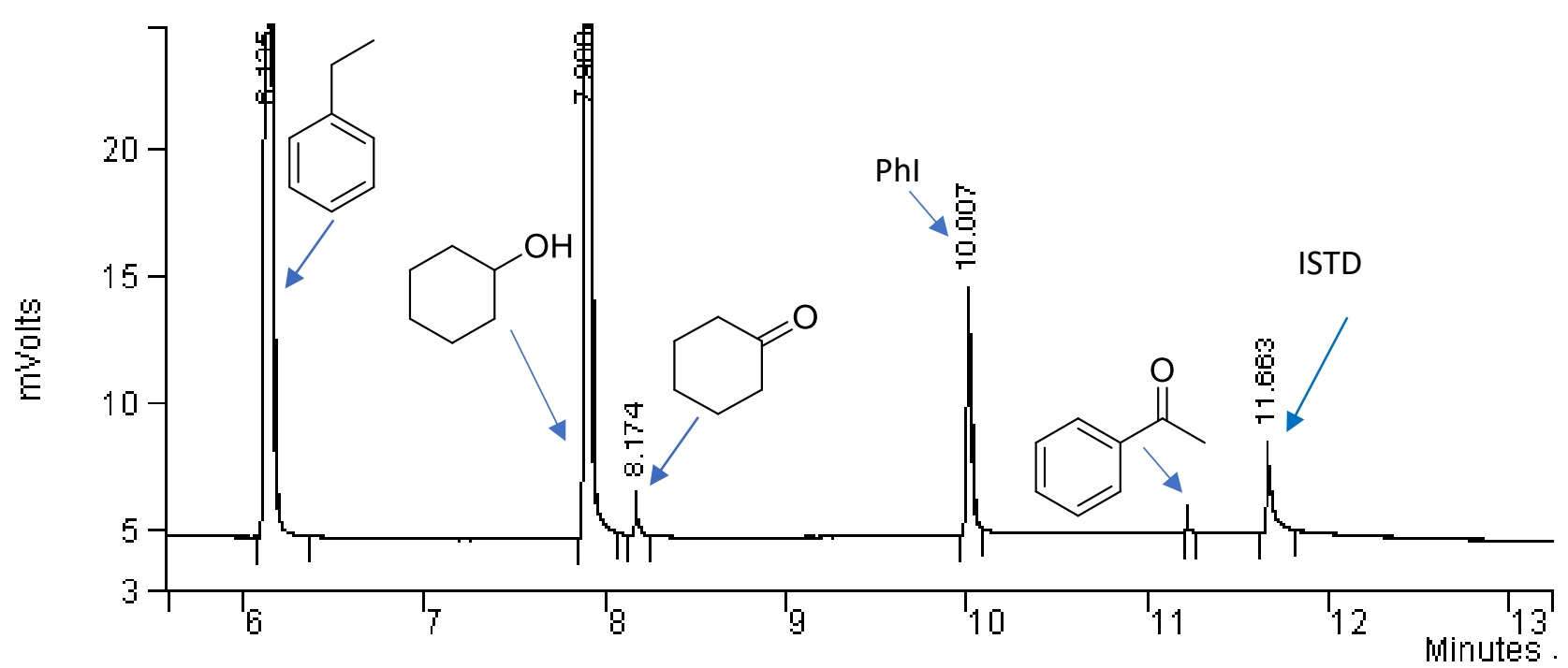

Figure S78. Chromatogram of competitive intermolecular oxidation of cyclohexanol and ethylbenzene with $\left[(\mathrm{Bn}-\mathrm{TPEN}) \mathrm{Fe}^{\mathrm{IV}}=\mathrm{O}\right]^{2+}$ in the presence of $20 \mathrm{~mol} \% \mathrm{NHPI}$ as mediator in $\mathrm{CH}_{3} \mathrm{CN}$. Reaction time 5 min. 


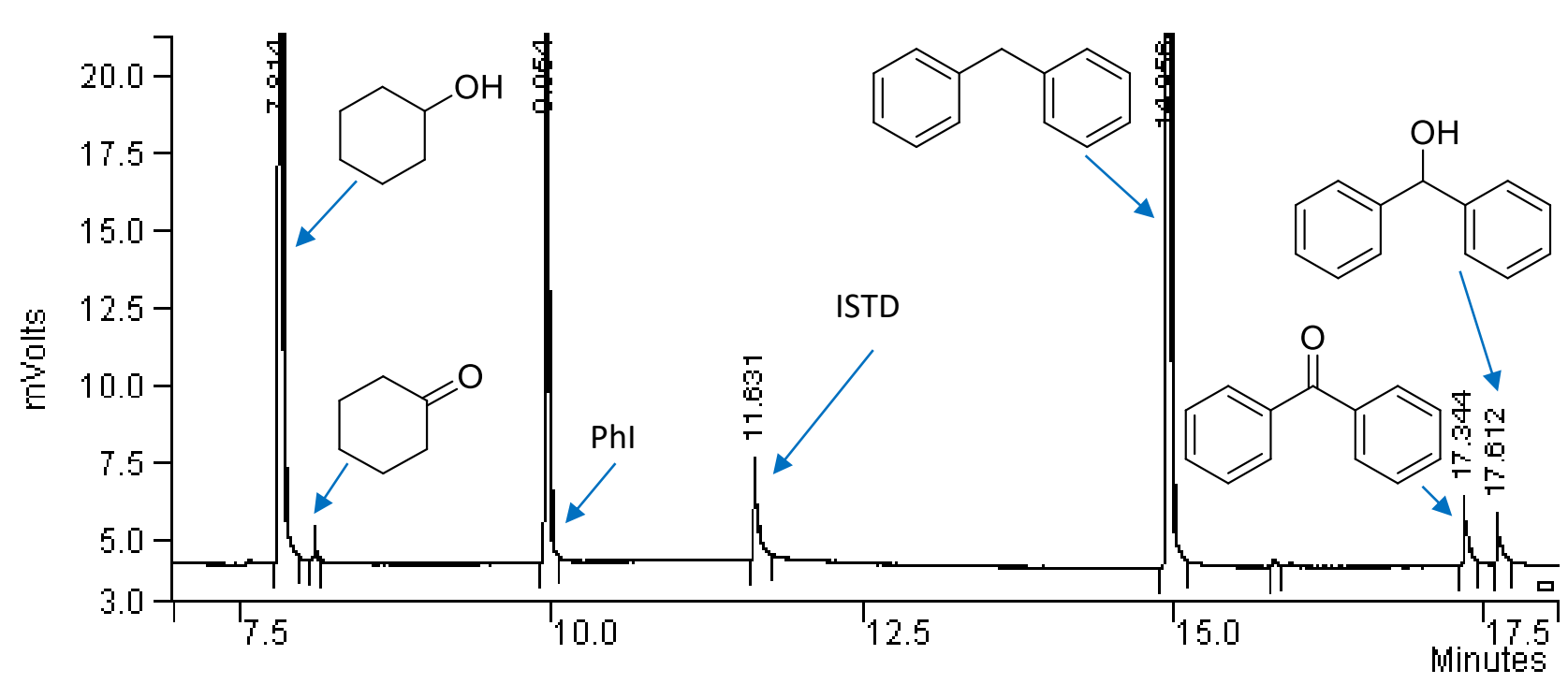

Figure S79. Chromatogram of competitive intermolecular oxidation of cyclohexanol and diphenylmethane with $\left[(\mathrm{Bn}-\mathrm{TPEN}) \mathrm{Fe}^{\mathrm{IV}}=\mathrm{O}\right]^{2+}$ in $\mathrm{CH}_{3} \mathrm{CN}$. Reaction time 5 min.

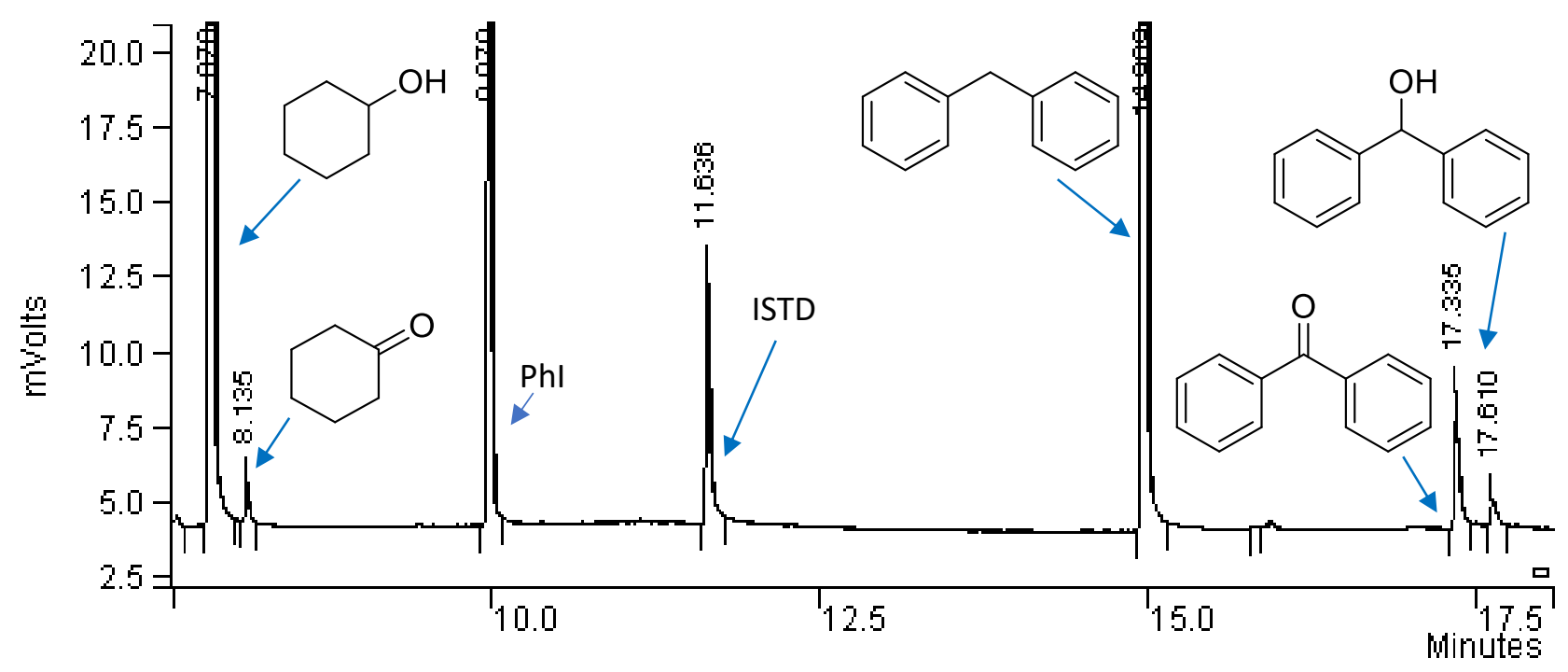

Figure S80. Chromatogram of competitive intermolecular oxidation of cyclohexanol and diphenylmethane with $\left[(\mathrm{Bn}-\mathrm{TPEN}) \mathrm{Fe}^{\mathrm{IV}}=\mathrm{O}\right]^{2+}$ in the presence of $20 \mathrm{~mol} \%$ NHPI as mediator in $\mathrm{CH}_{3} \mathrm{CN}$. Reaction time 5 min. 